\title{
MOBILIDADE E TRABALHO DOS AGRICULTORES DE BAIXA RENDA DO VALE DO RIBEIRA
}

\author{
WILSON JACOMINI
}


.1.

à Minha Família 


\section{AGRADEÇO}

à Escola Superior de Agricultura "Luiz de Queiroz" (ESALQ), ao Instituto de Pesquisas Econômicas (IPE), à Empresa Brasileira de Pesquisa Agropecuäria (EMBRAPA) e aos demais örgãos e instituições que participam do projeto de pesquisa "Alternativas de Desenvolvimento para os Grupos de Baixa Renda na Agricultura Brasileirall pela colaboração fundamental no fornecimento sempre oportuno e eficente dos dados que serviram de base para a elaboração da presente pesquisa.

ao Professor José Molina Filho pela valiosa e segura orienta ção neste trabalho e pelo estímulo e apoio recebidos durante todo o Curso de Pös-Graduação.

aos Professores Maria Ignez Guerra Molina, Thomas J. Burke e Maria de Lourdes T.B.Wiendl pelas valiosas observações, críticas e sugestões feitas na elaboração e leitura dos originais.

aos Professores José Albertino Rosärio Rodrigues, David G. Francis, Oriowaldo Queda, Fernando A. S. Rocha e Josë Ferrei ra de Noronha pela inestimável colaboração prestada no presente trabalho como docentes do Curso de Pös-Graduação. 
.lii.

ao Professor Frank Perry Goldman pelo apoio constante em nos sa carreira e a quem, principalmente, devemos nossa formação profissional.

ao Departamento de Educação da Faculdade de Filosofia, Cièncias e Letras de Rio Claro, ao Departamento de Geografia e Planejamento e Departamento de Planejamento Regional, do Ins tituto de Geocièncias e Cièncias Exatas da UNESP, "Campus"de Rio Claro, por todo apoio e estímulos recebidos em nossa pro fissão e na realização do presente trabalho.

ao Professor Sebastião Baioco, companheiro no curso e na coleta dos dados na região pesquisada e aos demais colegas do Curso de Pōs-Graduação que também contribuíram para o presen te trabalho nos incentivando ou apresentando sugestões.

aos agricultores do Vale do Ribeira pela generosa acolhida, pela confiança e disposição em nos fornecerem os dados e informações sem os quais não seria possível a realização des te estudo.

à Srta. Inès Aparecida Galetti e Srs. Aldo Mortari, Luiz Garrito e Lázaro Martins pela colaboração e zelo dispensados na fase de impressão do presente trabalho. 
iv.

a todos os funcionärios do Centro de Processamento de Dados e do Departamento de Economia e Sociologia Rural da ESALQ/ USP que também contribuíram, direta ou indiretamente, para a realização da presente pesquisa. 
$1 N D \perp C E$

päginas

LISTA DAS TABELAS ...................... vi i RESUMO .............................

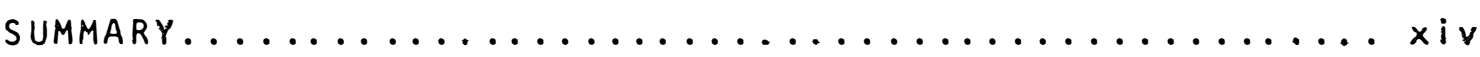

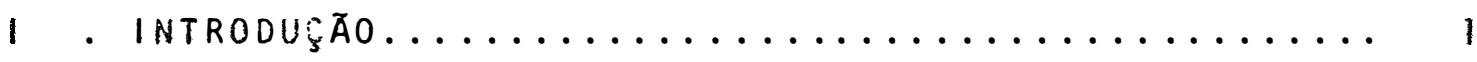

1. Mobilidade e Desenvolvimento Söcio-Econōmico... I

2. Colocação do Problema da Pesquisa........... 5

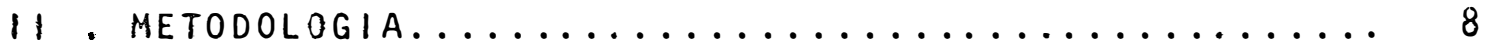

1. Seleção da Ârea e da População Estudada....... 8

2. Alguns Problemas de Conceituação e de Metodolo gia............................. 10

3. Coleta e Organização dos Dados da Pesquisa..... 18

111. A REGIÃO E A POFULAÇÃO ESTUdADA.............. 2 I

1. Caracteristicas Gerais....................21

2. A Produção Agrícola.................... 24

3. Mão-de-obra e Aspectos Educacionais.......... 30

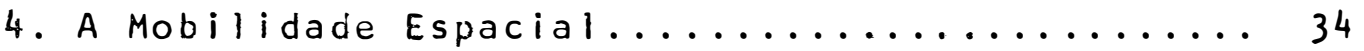

IV . MOBILIDADE E TRABALHO DOS AGRICULTORES.......... 37

1. A Hierarquia de Prestígio Ocupacional........ 37

2. A Mobilidade Social dos Agricultores........ 54

3. Mudanças na Estrutura 0cupacional........... 81

4. Sucesso e Fracasso na Mobilidade dos Agriculto-

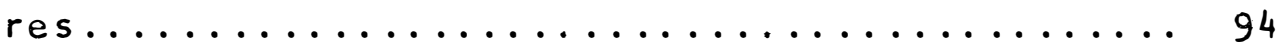




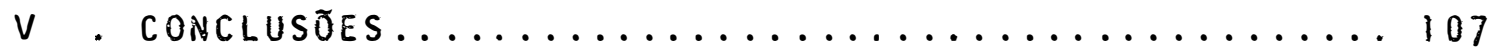

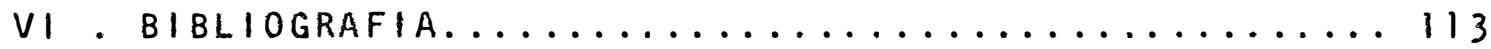

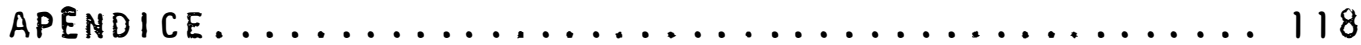


.vii.

\section{LISTA DAS TABELAS}

TABELAS

páginas

1. População Rural e Urbana dos Municípios do Vale

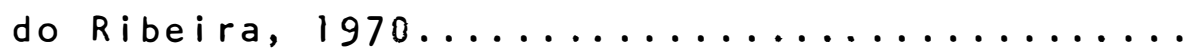

2. Distribuição dos Imóveis Rurais do Vale do Ribeira, segundo as Classes de Area, 1972......

3. Mecanização Agrícola da Região Sudeste, do Estạ do de São Paulo e do Vale do Ribeira, 1970....

4. Grau de Escolaridade dos Agricultores Entrevistados, segundo as Categorias de Trabalhadores

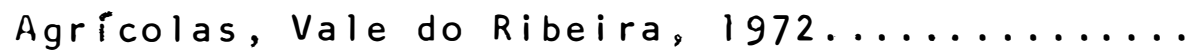

5. Distribuição Percentual da Mão-de-obra Agrícola, segundo a Area dos Imóveis Rurais, no Vale do

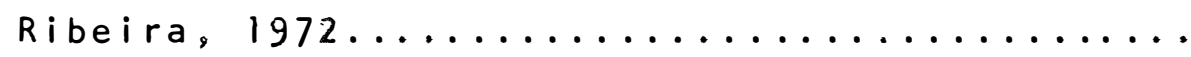

6. Distribuição da ocupação Humana, segundo as Classes de Área dos Imōveis Rurais, no Vale do

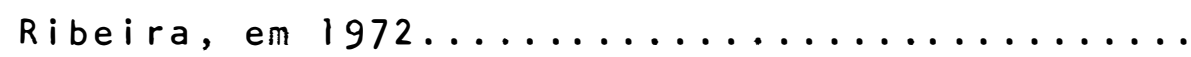


7. Frequéncia e Percentagem dos Agricultores Entrevistados, segundo as Categorias de TrabaIhadores Agrícolas, Vale do Ribeira, 1973....

8. Distribuição Percentual dos Julgamentos dos Agricultores Entrevistados, quanto ao Prestígio atribuído às Categorias de Trabalhadores Agrícolas, Vale do Ribeira, 1977..........

9. Distribuição Percentual dos Agricultores Entrevistados, segundo a Receita Mensal de suas Famílias e as Categorias de Trabalhadores Agrícolas, Vale do Ribeira, 1973..........

10. Distribuição Percentual dos Agricultores Entrevistados e de seus pais, segundo as catego rias de Trabalhadores Agrícolas (amplas cate-

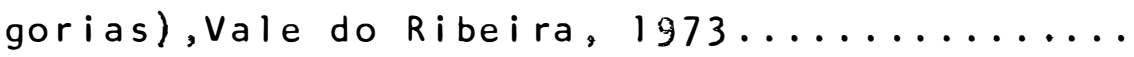

11. Distribuição Percentual dos Agricultores Entrevistados e de seus pais, segundo as Catego rias de Trabalhadores Agrícolas, Vale do Ri-

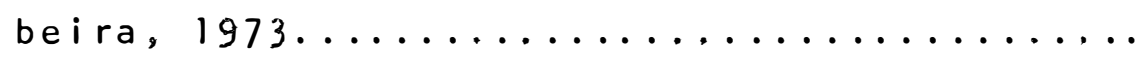


12. Frequência e Percentagem dos Agricultores Entre vistados, que estão na mesma Categoria ou em Cá tegorias de Trabalhadores diferentes daquelas

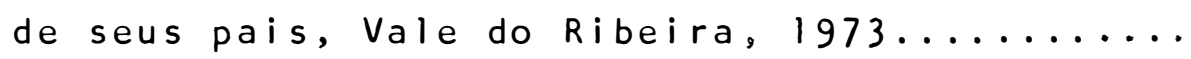

13. Mobilidade Social dos Agricultores Entrevistados e seus Lugares de Origem, Vale do Ribeira,1973..

14. Frequéncia e Percentagem dos Agricultores e de seus Pais, segundo as Categorias de Trabalhado-

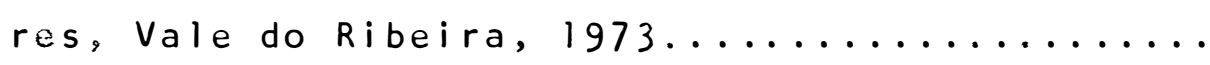

15. Distribuição Percentual dos Agricultores, segundo as Categorias de Trabalhadores Agrícolas e suas Indicações dos Locais para Mudança de Residên-

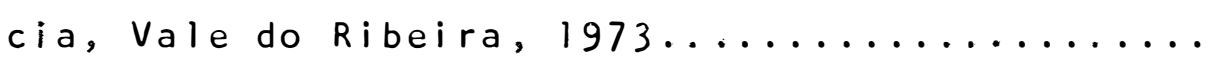

16. Frequéncia e Percentagem da Mobilidade Social dos Agricultores, Vale do Ribeira, 1973........

17. Distribuição Percentual dos Proprietärios,Arrendatärios e Parceiros e suas Aspirações quanto ao Cultivo de uma Area Maior, Vale do Ribeira,1973. 
18. Frequência e Percentagem dos Agricultores, segundo as Categorias de Trabalhadores Agrícolas e sua procura de Trabalho Adicional, Vale do Ribeira, $1973 \ldots \ldots \ldots \ldots \ldots \ldots \ldots \ldots \ldots \ldots \ldots \ldots \ldots \ldots$

19. Distribuição Percentual dos Agricultores,segun do as Categorias de Trabalhadores Agrícolas, re lativas aos seus Trabalhos Principais e Adicio nais, Vale do Ribeira, $1973 \ldots \ldots \ldots \ldots \ldots \ldots$

20. Distribuição do Total dos Imóveis Rurais do Vale do Ribeira, em $1972 \ldots \ldots \ldots \ldots \ldots \ldots$

21. Distribuição da 0cupação Humana dos Imóveis Ru rais do Vale do Ribeira, em 1972...........

22. Distribuição da Mão-de-obra Agrícola,segundo a Area dos Imóveis Rurais, no Vale do Ribeira, em

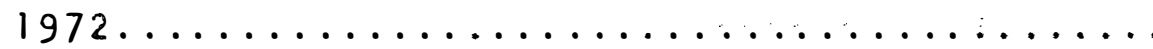

23. Força de Trabalho na Zona Rural do Estado de São Paulo, $1955 \ldots \ldots \ldots \ldots \ldots \ldots \ldots \ldots \ldots$ 
. $x i$.

MOBILIDADE E TRABALHO DOS AGRICULTORES DE BAIXA RENDA DO VALE DO RIBEIRA

Wilson Jacomini

ORIENTADOR: José Mol ina Filho

R E S U P 0

os beneficios do desenvolvimento sócio-econômi co no Brasil não têm alcançado algumas de suas äreas rurais pobres. A presente pesquisa analisa os problemas da mobilida de e trabalho dos agricultores numa dessas āreas. A população estudada foi escolhida ao acaso através dos cadastros de proprietārios do INCRA, seus dados foram coletados entre 1973 e 1977 e em função deles definimos as seguintes categorias de agricultores e sua respectiva hierarquia de prestigio: 11 proprietārios, 21 arrendatārios, 31 parceiros, 41 as salariados fixos $e$ 5l assalariados eventuais. A mobilidade estudada refere-se às mudanças dos agricultores através dessas categorias.

Os estudos sobre a mobilidade demonstram que os filhos tendem a permanecer nas mesmas categorias sōcioeconômicas de seus pais. Foi isto também o que verificamos considerando apenas tres categorias de agricultores, ou sejam: 11 proprietārios, 2l arrendatārios e parceiros e 31 as- 
. xii.

salariados fixos e eventuais. Vimos que ha associação positiva e significante entre essas categorias pois, em todas elas o nümero de agricultores que permaneceram na mesma cate goria de seus pais foi sempre maior que o dos que mudaram. Entretanto esta associação demonstrou ser relativamente fraca e as categorias consideradas são excessivamente amplas, pois podem estar escondendo a mobilidade que dentro delas ocorre. Consideramos então as cinco categorias que inicialmente foram definidas e, no mesmo nível de significância, ve rificamos que não mais havia a associação anteriormente encontrada: apenas $32,0 \%$ dos agricultores permaneceram na mesma categoria de seus pais, 19,1\% mudaram para categorias superiores e 48,9\%, para categorias inferiores.

os custos da mobilidade são mais elevados quan do ela $\bar{e}$ descontínua e os casos mais extremos dessa mobilida de faram os dos filhos dos proprietärios pois, $17,3 \%$ deles tornaram-se assalariados eventuais. A mobilidade parcialmente bloqueada também é bastante significativa entre os agricultores estudados pois, por exemplo, dentre os que inicia ram suas carreiras como filhos de assalariados eventuais, 24,0\% conseguiram tornar-se apenas assalariados fixos e $20,0 \%$ subiram apenas até as categorias dos parceiros e arren datärios. Também a mobilidade não institucionalizada é muito comum na população estudada e tem introduzido muita desorganização em sua estrutura ocupacional. 
.xiii.

A tecnologia agrícola moderna e as aplicações das novas leis sobre a terra e sobre os trabalhadores rurais, têm provocado muitas mudanças na região. Isto tem aumentado a mobilidade dos agricultores, pois esta $\bar{e}$ um meio deles se adaptarem às mudanças que ocorrem. Assim muitas mudanças tambèm são introduzidas nas categorias da estrutura ocupacional. Por exemplo, a categoria dos proprietārios foi re duzida pela metade (de 56,5\% para $28,3 \%$ do total) $e$ as demais aumentaram bastante na estrutura relativa aos agriculto res, quando comparadas com as categorias da estrutura relativa a seus pais.

As pessoas são mais estimuladas $\bar{a}$ mobilidade quando vêem suas ocupações como um meio de obterem sucesso. Entre os agricultores de baixa renda, entretanto, dificilmen te isto ocorre pois, para eles geralmente as ocupações representam apenas um meio de sobrevivencia. Por isso vimos, por exempla, que 32,0\% dos agricultores estudados estão imobiliza dos no fundo da estrutura ocupacional e têm se transformado em paupērrimos. Seu pauperismo tem muito que ver com sua imo bilidade, pois é consequência de se terem fechado para eles os canais da mobilidade que os levaria para fora de uma cate goria pobre. São eles principarmente que vivem os dramas da pobreza no campo. 
.xiv.

MOBILITY AND WORK OF THE LOW INCOME FARMERS IN THE RIBEIRA RIVER VALLEY

\author{
Wilson Jacomini \\ ORIENTADOR: Josē Molina Filho
}

\title{
SUMMARY
}

The benefits of the social

economical

development in Brazil have not reached some of its poor rural areas. The present research analyses the problems of the farmers' mobility in one of these areas. The population studied has randomly been chosen through the INCRA cadastre of real estate owners and the data about it has been collected between 1973 and 1977 and in accordance with them we have defined the following categories of farmers and their respective prestige hierarchy: 11 land owners, 21

tenants, 31 sharers, 41 permanent employees, and 51 temporary employees. The mobility studied concerns the farmers' changes through these categories.

The studies about the mobility demonstrate that the farmers' sons tend to remain in the same social economical categories as their fathers. That was als what we realized by considering three categories alone, as follows: 11 land owners, 21 tenants and sharers and 31 
.$x \cup$.

permanent employees and temporary employees. We

realized

that there is a significant and positive association among these categories, for in ale of them the number of farmers that remained in the same category as their fathers was always larger than the number of farmers who moved to another category. This association, however, turned up to be relatively weak and the categories considered are exceedingly broad, for they can be concealing the mobieity occurring within themselves. We considered, then, the five categories we had defined at the beginning of this paper, and at the same level of significance, we realized that the association we had found before no more existed: only $32.0 \%$ of the farmers remained in the same category as their fathers; $19.1 \%$ moved up to higher categories, and 48.9\% moved down to lower categories.

The mobility costs are higher when

the mobility is discontinuous and the most extreme cases of this mobility were the ones of the land owners'sons, for $17.3 \%$ of them became temporary employees. The partially blocked mobility is also very significant among the farmers because, for instance, among those who have begun their careers as sons of temporary employees, $24.0 \%$ have accomplished to become only permanent employees and $20.0 \%$ moved up only to the sharer and tenant categories. The non-institutionalized mobility is also very common in the population studied and 
.xvi.

has brought a great deal of disorganization into occupational structure.

The modern agriculturat technology and

the enforcement of the new laws on the land and on the

rural workers have provoked a great deal of changes in the region. This has increased the farmers' mobility because this is a means they have to adapt themselves to the changes that take place. Thus many changes are also introduced in the categories of the ccupational structure. For instance, the land owner category has been reduced by the half Ifrom 56.5\% it dropped to $28.3 \%$ of the totall and the remaining categories have had a great increase in the structure concerning the farmers as compared with the categories of the structure regarding their fathers.

The people are more stimulated toward mobility when they see their occupations as a means to reach success. Among the low income farmers, however, this seldom happens because for them, in general, their occupations represent just a means of earning their living. Hence we have seen, for instance, that $32.0 \%$ of the farmers is immobilized at the bottom of the occupational structure and has been becoming extremely poor. Their pauperism has much to do with their immobility, for this is a consequence of the closing for them of the mobility channels which would lead them out of a poor category. They are the ones most of all who endure the drama of poverty in the rural area. 


\section{INTRODUÇת̃}

1. Mobilidade e Desenvolvimento Sócio-Econômico

o crescimento econômico no Brasil, como em ou tros paises em desenvolvimento, tem levado a uma intensa e desigual urbanização e industrialização de suas regiōes e a um răpido desenvolvimento tecnológico. Os pequenos produtores e os trabalhadores agricolas têm sido pouco beneficiados e atë mesmo prejudicados com essas transformaçōes, as quais não raro os tem levado ao êxodo rural. As descontinui dades e consequencias do crescimento econômico também têm levado ao aparecimento dos chamados "bolsōes de pobreza" ou "áreas de pobreza rural", onde sobrevivem os agricultores de baixa renda do país. Segundo PATRICK (1975a: 2), presentemente uma atençāo cada vez maior vem sendo dada ao estudo 
desses agricultores e um consenso cada vez maior vem se fir mando de que, os planos de desenvolvimento do setor rural devem visar, tambēm, a melhoria do bem-estar da população rural e não simplesmente o aumento da produção no setor.

Sảo muitos os fatores de desenvolvimento que provocam mudanças no setor agricola. Alguns deles são: a expansāo das äreas de exploração agrícola, o desenvolvimento da tecnologia de produçāo, o aumento das migraçōes inter nas e o desenvolvimento da escolarização. Todos esses fatores contribuem para tornar menos rígidas e mais diversifica das as categorias dos trabalhadores agricolas fazendo com que surjam canais de mobilidade entre elas. Assim,esses fatores tornam o desenvolvimento e a mobilidade social estre tamente relacionados e por isto, segundo GERMAH!l (1966), a pröpria mobilidade pode ser considerada como um aspecto importante do desenvolvimento, uma vez que ela se acelera e se mantem alta, enquanto dura o desenvolvimento.

Os estudos sobre o desenvolvimento e mobilida de em geral tëm demonstrado que, na medida em que se proces sa o desenvolvimento söcio-econômico de um paîs, hä mudança de suas têcnicas mais simples de produção agrícola para téc nicas mais complexas e sofisticadas e, enquanto que o nümero dos seus trabalhadores especializados tende a aumentar, o dos seus trabalhadores agricolas tende a diminuir. Segundo QUEIROZ (1365:7), o desenvolvimento söcio-econômico bra- 
sileiro tem seguido essas mesmas tendencias e tem acentuado a mobilidade no setor agrícola, näo apenas porque tem criado e desenvolvido ocupaçōes novas, mas tambëm porque tem atrofiado e extinguido muitos cargos ocupacionais. Esta atrofia e extinçāo tem ocorrido principalmente no setor agri cola, pois alí, em geral o desenvolvimento tem levado à ado çăo de uma tecnologia de produçaó relativamente moderna. . Nas äreas onde isto ocorre, a pröpria mobilidade parece ser um produto da adaptaçāo às mudanças tecnológicas ou é um produto de adaptaçäo a outras mudanças provocadas pelo desenvolvimento.

Consequentemente, o desenvolvimento söcio-eco nómico estimula os agricultones à mobilidade e contribui pa ra elevar seus niveis de aspiraçāo. Segundo PASTORE (1974: 14), entretanto, frequentemente os esforços dos agricultores no sentido da mobilidade social têm resultado apenas nu ma mobilldade espacial ou geogräfica, a qual representa o fracasso da mobllidade desejada. Em consequência aumentam as diferenças entre as aspiraçōes de mobilidade e a realida de para os agricultores, aumentando assim a instabilidade e a insatisfaçāo na sua população. Essas frustraçōes tèm contribuido, inclusive, para aumentar os protestos no setor agricola e a própria estabilidade da sociedade nesse setor pode depender de como as autoridades constituidas lidam com esses protestos.

Nos países em transição de um estägio essen- 
cialmente agrícola para um estägio industrial, o desenvolvi mento söcio-econômico pode alterar a estrutura ocupacional. So Brasil, na dēcada de 60 caracterizada por um grande cres cimento econōmico, a força de trabalho na agícultura diminuiu de $\$ 6,0 \%$ para $40,0 \%$ do total (PATRICK, 1975b:7). Acompanhando o desenvolvimento o processo de industrialização também pode modificar a estrutura ocupacional provocando uma reorganizaçāo da força de trabal ho, levando cada trabaIhador a empregar melhor suas aptidōes. Heste caso a pröpria mobilidade resultante se constitui num fator de desenvolvimento. Foi no sentido de estudar alguns aspectos do desenvolvimento söcio-econômico no Brasil que, em 1972, se deu inicio ao projeto de pesquisa "Alternativas de Desenvol vimento para os Grupos de Baixa Renda na Agricultura Brasileira". Participam desse projeto a Escola Superior de Agricultura "Luiz de Queiroz" de Piracicaba, a Empresa Brasileira de Pesquisa Agropecuäria, o Instituto de Pesquisas Econōmicas e outros örgäos interessados na aceleraçāo do desenvolvimento no país. O presente trabalho baseia-se nesse projeto, entretanto restringe-se a uma populaçāo mais I i mitada e a um problema específico, ou seja, o de estudar a mobilidade e trabalho dos agricultores de baixa renda do Va le do Ribeira, no Estado de Sāo Paulo. 


\section{Colocação do Problena da Pesquisa}

A estrutura ocupacional compreende toda interaçäo regular que ocorre entre as pessoas em função de suas ocupaçōes e inclui os värios meios pelos quais os aspectos econômicos dos papeis sociais säo diferenciados e organizados (MOORE, 1966:134). SEgundo HUTCHInsor ( 1960 : 19), nessa estrutura as ocupaçōes podem estar organizadas em estratos superpostos ou em niveis, segundo uma hierarquia de prestigio. Toda mobilidade ascendente ou descendente atraves dessa estrutura implica em mudanças para posiçōes que possuem mais ou menos prestigio, respectivamente e toda mobilidade horlzontal implica em mudanças entre posiçōes que possuem prestigio semel hante. Os conceitos de mobi lidade vertical e horizont podem ser utilizados nos estu dos da mobilidade individuos ou de grupos de pessoas e podem se referir tanto à mobilidade estrutural como à mobilidade por substituiçāo. A mobilidade estrutural refere-se às mudanças na ordem, no volume e no nümero dos estratos considerados. A mobilidade por substituição refere-se às mudanças através das quais as pessoas passam a ocupar as posiçōes deixadas por outras pessoas e portanto näo implica em mudanças estruturais. Consequentemente a mobilidade estrutural produz mudanças na estrutura ocupacional e a mobilidade por substituição teoricamente deixa-a intacta em sua forma. 
Foi considerando o processo de mobilidade e os problemas de desenvolvimento acima colocados que nos pro pusemos realizar este estudo sobre a mobilidade e trabalho dos agricultores de baixa renda do Vale do Ribeira, no Estado de são paulo. A mobilidade desses agricultores,através das categorias de trabalhadores agricolas, parece indicar a existência de uma hierarauia de prestigio entre elas e essa hierarquia parece ter sempre um sentido de ascensão e de descenso social. Considerando essa hierarauia, alguns a tores têm indicado que na regiāo estudada muitos trabalhado res agricolas comuns têm conseguido tornar-se parceiros e muitos destes têm chegado a ser proprietärios; por outro la do, hä tambêm muitos proprietärios que têm se tornado parceiros e muitos desses tambëm têm se tornado assalariados. Em consequencia, verificamos que existem muitos casos de mobilidade na população estudada. Entretanto segundo PATRICK (1975a), apesar desses casos serem bastante conhecidos, são necessārios outros estudos para que essa mobilidade, a hierarquia de prestigio e a estrutura ocupacional da região possam ser melhor conhecidas e analisadas. São e ses os problemas que procuramos aqui estudar.

Mesta pesquisa sempre estaremos interessados na mobilidade dos agricultores de um modo geral, porém mais especificamente ela será analisada em termos intergeracionais, isto $\vec{e}$, em termos das relaçöes entre as categorias de 
trabalho dos agricultores e as de seus pais. FOLKMAH e CoUHIG (1963:407) em seus estudos verificaram que 85,0\% dos agricultores entrevistados mantinham-se em ocupaçōes semeIhantes às de seus pais e, nesse sentido, analisaram a herança ocupacional e a herança da pobreza que geralmente os pequenos agricultores deixam para os seus filhos. Estas são algumas das questōes que tambëm procuraremos analisar aqui, verificando quais são as direçōes da mobilidade realizada pelos agricultores, quais os grupos que mais frequentemente subiram ou desceram na estrutura ocupacional e quais as mudanças ocorridas nessa estrutura. Sāo estas, portanto, algu mas das questões que procuraremos esclarecer no presente trabalho, admitindo juntamente com PATRICK (1975b:11) que, se conseguirmos identificar o grau em que os agricultores estão fixos ou möveis em suas categorias de trabalho e se conseguirmos caracterizar os diferentes grupos nesse sentido, isto poderá ser de grande valia para a definição dos programas de ajuda a eles destinados, permitindo que sejam assistidos de modo mais adequado à situação particular de cada um. 
II. METODOLOGIA

1. Seleção da Area e da População Estudada

o projeto de pesquisa "Alternativas de Desenvolvimento para os Grupos de Baixa Renda na Agricultura Bra sileira" visa analisar a situação dos agricultores de baixa renda em tres diferentes regiões do país e para isso selecionou, em cada uma delas, as áreas mais representativas da pobreza rural. As äreas selecionadas foram o Vale do Ribeira, no Estado de São Paulo; a zona da Mata e Campos das Ver tentes, em Minas Gerais e o Municipio de Canindē, no Sertão Central do Ceará. Como dissemos, o presente estudo utiliza os dados coletados através desse amplo projeto de pesquisa. Entretanto se restringe a uma população mais limitada e a 
um problema especifico, ou seja, o de analisar a mobilidade e trabalho dos agricultores de baixa renda do Vale do Ribe ra, no Estado de São Paulo.

A área selecionada para o presente estudo cons titui-se numa microrregião homogênea, onde a agricultura de baixa renda representa uma caracteristica importante. Para a definição da população e seleção da respectiva amostra, estudada pelo projeto de pesquisa "Alternativas de Desenvol vimento para os Grupos de Baixa Renda na Agricultura Brasileira", foram usadas as relaçöes de proprietārios fornecidas pelo INCRA e a partir delas foi selecionada ao acaso uma amostra de pequenos proprietärios, cujas propriedades eram menores que o mödulo de suas respectivas regiōes (PATRICK, 1975a:4). Dentre os proprietärios sorteados foram eliminados os que possuiam duas ou mais propriedades e tambèm os que tinham apenas sitios recreativos. Como não ha via lista das pessoas pertencentes às demais categorias de agricultores, foram incluidos na amostra todos os agricultores não-proprietärios que moravam próximos aos pequenos proprietärios sorteados. Assim foram incluidas na amostra as pessoas pertencentes às värias categorias de agricultores, das diferentes regiöes estudadas, sendo que no Vale do Ribeira os agricultores estudados residem nos municipios de Jacupiranga, Miracatü, Pariquera-Açü e Pedro de Toledo. Segundo PATRICK (1975a:32), há grande variação na renda dos 
agricultores dessa região. Entretanto, entre os agricultores aqui estudados, a renda "per capita" familiar ( produto da divisão da renda total da familia, pelo nümero de seus membros) varia apenas entre $15 \%$ e $30 \%$ abaixo da renda "per capital estimada no Brasil, em 1973, que era de US\$700 anu ais. Portanto, são esses os niveis que caracterizam a população estudada como sendo de baixa renda e composta por agri cultores que residem numa região de pobreza rural.Consequen temente os agricultores estudados não representam o conjunto total dos agricultores brasileiros. Entretanto, segundo PASTORE (1974), eles representam os grupos de baixa renda da agricultura brasileira, pois vivem numa situação de sub sistência, são típicos das äreas rurais pobres e representam os problemas da pobreza rural difundidos no pais.

\section{Alguns Problemas de Conceituação e de Metodologia}

A descrição e anălise da mobilidade aqul estú dada subordina-se aos conceitos de mobilidade social. Essa mobilidade implica essencialmente no movimento de grupos ou de pessoas através da estrutura social, implica nas mudanças de uma posição social a outra ou de uma categoria social a outra. Segundo BROOM e SELZNICK (1968:178), a mobili dade social frequentemente tem sido inferida a partir da mobilidade ocupacional e essa inferēncia geralmente justifi ca-se porque a posição do individuo no padrão total das de- 
sigualdades depende amplamente de sua ocupaçāo. Segundo GALESKI (1972:35), toda ocupaçāo consiste num complexo de ati vidades que requer treinamento especial, è executada regularmente, corresponde à prestação de serviços à outras pessoas e representa um meio regular de sustentação ou de sobrevivencia. As categorias dos agricultores ou dos trabalha dores agricolas referem-se às classificações de todo conjun to de agricultores que executam suas ocupações, segundo as mesmas condiçōes ou segundo condiçōes semelhantes de traba1ho. Na presente pesquisa, no sentido de analisarmos a mobi lidade dos agricultores, através das categorias de trabalha dores, nos baseamos principalmente nos estudos de ETTORI (1961), nos da Fundação Getülio Vargas (1956) e nas observa çöes de PATRICK (1975a) para definirmos as categorias estudadas. Assim definimos as seguintes categorias de trabalha dores, as quais representam os estratos da estrutura ocupacional relativa à população estudada: pequenos proprietários, arrendatärios, parceiros, assalariados fixos e assala riados eventuais. Como podemos perceber, essas categorias são bastante abrangentes. Entretanto não chegam a representar, por si mesmas, toda a posição söcio-econômica dos agr cultores, uma vez que por status söcio-econōmico devemos en tender a posição social das pessoas, consideradas em função da mëdia de suas posiçōes ocupacionais e em função de seus niveis de renda e de educação (KAUFMAN et alii, 1953). Con- 
sequentemente as categorias definidas, de fato não abrangem todos os aspectos da posição social dos agricultores. Entre tanto devemos admitir que elas são bastante relevantes e distintas entre si, uma vez que permitem distinguir entre proprietärios e não-proprietärios e entre responsäveis (pro prietários, arrendatários e parceiros) e nāo-responsāveis (assalariados) pela produção.

Segundo GALESKI (1972:46), as atividades dos fazendeiros ou dos proprietärios de terra, embora sejam for malmente reconhecidas como constituindo uma ocupação ou como pertencentes a uma categoria ocupacional, de fato nāo são nem podem ser tratadas como tal, pois nenhum outro tipo de trabalho possui atividades täo amplas e tão abrangentes, combinando em si atividades pertencentes à värias ocupaçöes. De fato é dificil definir os proprietärios de terra como uma ocupação ou como uma categoria ocupacional, se as suas atividades são dirigidas apenas para a obtenção dos lucros ou dos proventos relativos às suas propriedades, ou se eles não trabal ham como diretores de suas empresas. Isto è ainda mais comum no caso dos grandes proprietärios, os quais geralmente sāo apenas os organizadores e quase nunca os executantes dos trabalhos em suas propriedades. Entretanto as dificuldades de se aplicar o termo categoria de agricultores ou de trabal hadores agrícolas aos pequenos proprietários que operam as suas propriedades, como é o caso dos 
agricultores em questão, são bem diferentes. No caso dos pe quenos proprietärios aqui estudados, suas familias trabaI ham suas pröprias terras, eles prōprios são os empresärios, os produtores e vendedores dos produtos colhidos e executam os värios outros serviços de suas propriedades. Portanto seus trabalhos envolvem atividades bastante variadas e, assim, não se constituem numa ocupação especifica. Dadas essas consideraçōes então devemos admitir que, ser fazendeiro ou ser grande proprietärio de terra, pode corresponder quase exclusivamente a uma posição de classe ou a um status so cial. Porēm ser um pequeno proprietärio ou um pequeno produtor que trabalha sua terra, como è o caso de alguns agricultores aqui estudados, corresponde mais a uma categoria de agricultores ou de trabalhadores agricolas.

Considerando o processo de mobilidade, verif camos que as variäveis cruciais ou mais importantes que aqui deverão ser estudadas são as que se referem às posiçöes dos agricultores e de seus pais nas categorias de trabalhadores e a mobilidade dos agricultores através delas. As posições dos agricultores e de seus pais serão definidas em função das condiçōes em que eles exercem suas ocupações, oque os situará nas categorias de trabalhadores. A mobilida de estudada refere-se às mudanças realizadas pelos agricultores em suas posiçōes relativas a essas categorias, tendo como ponto de partida as posições ocupadas pelos seus pais. 
Quanto à sua direção, essa mobilidade será analisada em seu sentido ascendente ou descendente, conforme os agricultores tenham se movido para cima ou para baixo na hierarquia de prestígio ocupacional; quanto à sua magnitude, ela serä estimada em função das diferenças entre as posiçöes dos agricultores e as de seus pais. Por exemplo, segundo os julgamentos dos agricultores, as categorias dos trabalhadores agrícolas compöem a seguinte hierarquia, conforme sua ordem decrescente de prestígio:

$$
\begin{aligned}
& \text { 1- Proprietärios, } \\
& \text { 2- Arrendatärios, } \\
& \text { 3- Parceiros. } \\
& \text { 4- Assalariados fixos, } \\
& \text { 5- Assalariados eventuais. }
\end{aligned}
$$

Consequentemente um agricultor, filho de proprietärio, que se tornou arrendatărio, realizou uma mobilidade descendente menor que outro, tambëm filho de proprietärio, que se tornou assalariado eventual: no primeiro caso, o agricultor desceu apenas uma categoria, enquanto que, no segundo, o agricultor desceu 4 categorias. Atravès desses exemplos vemos tambëm que, a posição dos pais representa apenas um pon to de partida em função do qual è avaliada a magnitude e a direção da mobilidade dos agricultores entrevistados, sobre os quais incide toda a análise da mobilidade.

$$
\text { No setor rural, frequentemente os trabalhado- }
$$


res têm mais de uma atividade, o que pode confundir o pröprio Censo, jä que um agricultor pode ser contado värias ve zes em diferentes categorias ocupacionais (QUEIROZ, 1965:36). De fato, no setor agrícola não è raro um agricultor ser, ao mesmo tempo, proprietário de terra, parceiro na propriedade vizinha e, ainda, tarefeiro nas horas livres. Segundo PATRICK (1975a:42), é assim também na região estudada, pois ali muitos agricultores também trabalham fora de sua princi pal unidade de produção. PEREZ (1975) observou que, na regiāo estudada, cerca de $40,0 \%$ dos agricultores desenvolveram atividades adicionais no ano agricola de $1973 / 74$ e notou que muitas atividades näo-agricolas lhes representam im portante fonte de renda. Dada essa complexidade e polivalên cia das ocupaçōes dos agricultores, tivemos que decidir em função de quais categorias de trabalhadores seriam definidas suas posiçōes. E as definimos em função das categorias principais ou mais importantes, às quais eles declararam pertencer na època da pesquisa. Na grande maioria dos casos, essas categorias foram por eles mencionadas em primeiro lugar, o que significa que eram aquelas com as quais eles mais se identificavam. Frequentemente essas categorias se referiam, também, à sua maior fonte de renda e às atividades nas quais eles dispendiam o maior nümero de horas de trabalho por dia. Para a definição da posição dos pais dos agricultores, consideramos também as categorias de trabalha 
dores que, nesse sentido, seus filhos mencionaram em primei ro lugar. Isto tambèm significa que eles identificavam seus pais mais com essas categorias e que elas correspondiam mais às suas ocupações principais. Como na população estuda da a média de idade dos agricultores $\vec{e} 43,5$ anos e, conside rando que as técnicas de pesquisa sobre a mobilidade intergeracional põem ênfase na correspondencia entre as idades dos pais e as dos filhos estudados, definimos a categoria de trabalhador dos pais dos agricultores em função das cate gorias que, segundo seus filhos, eles possuiam ao redor dos 40 anos de idade.

Como a presente pesquisa se refere aos estudos de mobilidade, também ela apresenta algumas deficiências metodolögicas que eles não têm conseguido eliminar. Por exem plo, esses estudos não contam ainda com uma base teörica adequada e por essa razão dependem essencialmente da metodo logia neles utilizada (KAUFMAN et alii, 1953:16). Quanto às categorias neles consideradas verifica-se que, se as mesmas são definidas muito amplamente, tendem a ocultar a mobilida de que dentro delas ocorre, uma vez que são igualadas, numa mesma categoria, posições que são significativamente diferentes. Consequentemente teremos a falsa impressão de estar diante de uma estrutura relativamente estätica, como se deu na presente pesquisa, quando os agricultores foram classifi cados em amplas categorias de trabalhadores (Tabela 10, p. 
50). Segundo DUNCAN (1966:56), os estudos de mobilidade tam bém apresentam deficiência, no sentido de que neles os dados em parte são colhidos retrospectivamente, uma vez que, por exemplo, inquire-se os entrevistados sobre o trabalho de seus pais. Segundo esse autor, nesses estudos è erro pen sarmos que através dos filhos possamos ter uma amostra ou informações fidedignas quanto à população dos pais no passado, pois, épocas e populações diferentes exigem amostras diferentes. Hos estudos de mobilidade intergeracional, entretanto, quase sempre a amostra relativa à população dos pais é obtida apenas através da escolha dos respectivos fiIhos e geralmente apenas estes são entrevistados. Finalmente DUNCAN observa tambëm que, os estudos de mobilidade têm - inconveniente de não apresentarem correspondência entre as idades nas quais se consideram as posições dos pais e as dos filhos, sendo irregulares, portanto, as comparações que entre elas se estabelecem. Nas suas conclusões, porém, DunCAN admite que, apesar dessas deficiencias introduzirem alguns problemas de significância e de validade nos estudos de mobilidade, elas não chegam a invalidä-los e se quisermos usar muitos dados sobre a mobilidade temos que aprender a lidar com essas deficiências, pois, embora existam algumas imprecisões nos seus estudos, isto não significa que eles sejam invālidos ou inūteis. Segundo WILENSKY (1966: 102), muitas deficiências dos estudos de mobilidade podem 
ser contornadas, se neles procurarmos analisar apenas os tipor mais importantes de mobilidade e suas descontinuidades. Na presente pesquisa, seguindo as sugestöes desses autores, sempre que possivel procuramo contornar algumas das deficièncias comuns desses estudos fazendo, como jä explicamos, com que as posições dos agricultores e de seus pais fossem consideradas nas épocas em que eles tinham idades semelhantes; também procuramos reduzir ao minimo o nümero das informações sobre os pais, as quais foram obtidas através dos filhos e, na discussão dos dados, procuramos analisar principalmente as descontinuidades na mobilidade.

\section{Coleta e Organização dos Dados da Pesquisa}

os questionários relativos ao projeto de pesquisa "Alternativas de Desenvolvimento para os Grupos de Ba xa Renda na Agricultura Brasileira" (nos quais se baseia o presente estudo), foram elaborados pelos técnicos das instituições nele envolvidas e foram aplicados principalmente pẹ los alunos dos cursos de pós-graduação das universidades que dele participam (PASTORE, 1974). As aplicaçōes dos questioná rios, nas diferentes regiōes estudadas, deu-se através de en trevistas realizadas com os chefes das familias dos agricultores, em anos sucessivos. Na presente pesquisa, dada a região selecionada para estudo, utilizamos apenas os questionā rios aplicados no Vale do Ribeira, em julho de 1973 e julho 
de 1974. O primeiro desses questionärios foi aplicado em 239 agricultores, versava sobre o ano agricola de $1972 / 73$ e colheu dados sobre os recursos das familias dos agricultores, seu capital humano, sua histöria e suas técnicas de produção. O segundo questionărio foi aplicado em 225 dos mesmos agricultores entrevistados no ano anterior e colheu dados so bre os aspectos sociológicos e politicos de suas familias e dados sobre suas atitudes quanto à tecnologia agrícola. Com base nesses questionärios e tendo em conta o problema da pre sente pesquisa, organizamos fichas individuais com dados relativos a cada familia ou a cada agricultor estudado. Foi a partir desses dados que construimos as tabelas e os quadros para a computação dos resultados relativos ao problema especifico da pesquisa em questão. A discussão dos resultados foi realizada principalmente em termos de frequencias, percentagens e Qui-quadrado $\left(x^{2}\right)$, uma vez que os dados relativos às variăveis estudadas foram classificados apenas em escalas nominais e ordinais.

Finalmente, para ganharmos maior insight sobre a população e sobre a região estudada, em julho de 1977 fize mos entrevistas e observações diretas nos municipios de Pedro de Toledo e de Miracatu. Nesses municipios entrevistamos 64 agricultores na zona rural, no sentido de observarmos suas condições de habitação, seu nivel de vida, suas proprié dades agricolas e procuramos definir melhor a estrutura ocu- 
pacional ou a hierarquia de prestigio existente entre as categorias dos agricultores. Nesse sentido pedimos aos entrevistados que considerassem as condições de vida e de trabalho, bem como os niveis de prestigio das diferentes categorias de agricultores a o ordenassem segundo uma hierarquia de prestígio. Foi atravēs desses julgamentos que pudemos definir a mobilidade ascendente e descendente na estrutura ocu pacional da população estudada. Paralelamente a esses trabaIhos, fomos selecionando e organizando os dados dos recenseamentos e de outros estudos sobre o Vale do Ribeira, no sentido de obtermos uma visão geral da região e um esboço dos aspectos econômicos, das condições de vida e sobretudo da pobreza da população estudada. 


\section{A REGIAOO E A POPULAÇAOO ESTUDADA}

\section{Caracteristicas Gerais}

A ärea estudada localiza-se na região sudeste do país e, dentre as suas regiöes, è nesta onde se faz o maior uso de terras aproveitáveis para a agricultura, é nela onde há o maior número de parceiros e arrendatärios, embora entre seus agricultores predominem os trabulhadores assalariados (PEREZ, 1975:37). Nesta região, a área focalizada localiza-se no Estado de São Paulo. De um modo geral, este Estado tem uma agricultura altamente mecanizada e, embora use uma percentagem relativamente pequena de sua população econo micamente ativa, sua agricultura tem um al to nivel de produtividade e de comercialização. Neste Estado, geralmente os 
assalariados fixos predominam nas grandes propriedades, os assalariados eventuais predominam nas propriedades médias e a māo-de-obra familial predomina nas pequenas propriedades. Nas grandes propriedades hä, em média, 6,5 residentes por imóvel e no Estado todo hä um grande deslocamento da população rural para a periferia das zonas urbanas, o que dă origem à formaçāo dos trabalhadores agrícolas volantes (PEREZ, 1975). No Estado de Sāo Paulo, a ārea focalizada localiza-se no Vale do Ribeira, que representa a micro-regiāo homogênea 265 (FIBGE, 1970), composta por dez municipios, conforme mos tra a Tabela 1 .

Esta tabela apresenta a relaçāo dos municípios do Vale do Ribeira e suas respectivas populaçōes, segundo o Censo de 1970. Atravès dela verificamos que, a microrregião em questāo é composta por municípios cujas populaçōes variam de 6.080 à 24.281 habitantes e em todos eles, exceto em Registro, a população rural è acentuadamente maior que a urbana. Segundo PATRICK (1975a), a microrregiāo em questāo caracteriza-se por municipios pouco desenvolvidos e em toda ela a agricultura de baixa renda tem um peso importante. Segundo PASTORE (1974:16), o Vale do Ribeira representa uma àrea de pobreza em meio a um Estado rico e is to é consequência das descontinuidades do desenvolvimento que se verifica no país. Como sabemos, esse desenvolvimento tem provocado intensa urbanizaçāo e industrializaçāo em vă- 
TABELA 1. Populaçāo Rural e Urbana dos Municípios do Vale do Ribeira, 1970.

\begin{tabular}{lccc}
\hline \multirow{2}{*}{ MUNICTPIOS } & \multicolumn{3}{c}{$P$ O P U LACAO } \\
\cline { 2 - 4 } & URBANA & RURAL & TOTAL \\
\hline Cananēia & 1.929 & 4.121 & 6.080 \\
Eldorado & 2.556 & 8.289 & 10.845 \\
Iguape & 8.903 & 10.308 & 19.211 \\
Jacupiranga & 6.730 & 9.540 & 16.270 \\
Juquiá & 3.665 & 8.984 & 12.649 \\
Miracatu & 2.175 & 11.963 & 14.138 \\
Pariquera-Açú & 1.850 & 5.956 & 7.806 \\
Pedro de Toledo & 1.817 & 4.278 & 6.095 \\
Registro & 12.617 & 11.664 & 24.281 \\
Sete Barras & 1.704 & 7.519 & 9.223 \\
\hline
\end{tabular}

FOATE: FIBGE, Censo Demogräfico - São Paulo, 1970.

rias regiōes, porém tem deixado de lado segmentos importantes da populaçāo, aumentando as desigualdades econômicas e sociais entre as diferentes äreas do país. E nessas äreas pouco desenvolvidas, ou äreas de pobreza rural, onde sobrevivem os grupos de baixa renda da agricultura brasileira. O Va le do Ribeira è uma dessas äreas e, por essa razāo, o Gover- 
no do Estado constantemente tem canalizado, para alí, muitos recursos visando atenuar os problemas existentes (PATRICK, 1975a:5). Os agricultores dessa região, cuja amostra è objeto do presente estudo, em geral säo pequenos proprietários, arrendatários, parceiros e assalariados. Segundo PASTORE (1974:14), esses agricultores têm achado dificil entrar para a agricultura comercial e, assim, se mantêm apenas numa agr cultura de subsistência. Segundo PEREZ (1975), entretanto,es sa. região não pode ser considerada apenas uma ărea de agricuI tura de subsistência, embora uma parte significativa de sua produção destine-se apenas à subsistência dos seus produtores. Mais exatamente, os agricultores estudados devem ser considerados representantes dos grupos de baixa renda da agricultura brasileira, ou representantes dos grupos de pobreza rural difundidos no país.

\section{A Produção Agrícola}

Na região estudada, em termos numéricos predominam os minifündios, porëm, em termos de ärea,predominam as grandes propriedades. Trata-se de uma região litorânea, onde o clima é úmido e o terreno è parcialmente acidentado. A Tabela 2 mostra a distribuiçāo de suas propriedades agrícolas, segundo as classes de ärea.

Esta tabela apresenta a distribuição das propriedades agrícolas, segundo as classes de ārea, no vale do 
TABELA 2. Distribuiçāo dos Imöveis Rurais do Vale do Ribeira, segundo as Classes de Area, 1972.

\begin{tabular}{|c|c|c|c|c|}
\hline \multirow{2}{*}{\multicolumn{3}{|c|}{$\begin{array}{c}\text { Classes de Area } \\
\text { (ha) }\end{array}$}} & \multicolumn{2}{|c|}{ Imóveis } \\
\hline & & & N: & $\%$ \\
\hline 0 & - & 50 & 5.293 & 68,5 \\
\hline 50 & - & 500 & 2.142 & 27,7 \\
\hline 500 & e & mais & 294 & 3,8 \\
\hline \multicolumn{3}{|c|}{ TOTAL } & 7.729 & 100,0 \\
\hline
\end{tabular}

FONTE: L.H. PEREZ (1975:106)

Ribeira, em 1972. Verificamos que, de fato, a percentagem das propriedades pequenas, isto è, com menos de 50 ha é relativamente grande, pois alcança $68,5 \%$ do total. Entretanto segundo PEREZ (1975:107), a maior parte da àrea corresponde a apenas $3,8 \%$ dos imóveis relativos às propriedades de 500 ha e mais. Segundo PEREZ, no Vale do Ribeira a topografia é acidentada, sujeita a inundaçōes e, por isso, sua àrea aproveitāvel é relativamente pequena. Mesmo essa àrea ainda é pouco explorada, pois apenas $30,9 \%$ dela é utilizada com as explorações agrícolas.

No Vale do Ribeira, $59,6 \%$ da ärea das grandes 
propriedades (500 ha e mais) é destinada à extração de madeí ra (PEREZ, 1975:107). Segundo SIMÃO E GOLDMAN (1958:64-68), seus grandes bananicultores têm por norma năo ocuparem suas terras com outros produtos, não possuem residencia em suas fazendas e apenas raramente nelas comparecem para rápidas vistorias. Geralmente suas lavouras ficam entregues à administradores cujo nivel de vida está apenas um pouco acima da quele dos trabalhadores agrícolas comuns. Cerca de $44.3 \%$ da àrea das pequenas propriedades (menos de 50 ha) è destinada à criação de gado, porém a pecuária pode ser considerada insignificante no Vale. Em todo ele predominam as culturas do chă, banana e produtos hortícolas. Em grande parte da região não se produz senão banana. Os bananais são roçados de 3 a 5 vezes por ano e as colheitas săo feitas 2 ou 3 vezes por mes. o chá é colhido o ano todo e as culturas temporärivas sāo plantadas até 2 ou 3 vezes durante o ano. Segundo PATRICK (1975a:38), 40,0\% dos parceiros e arrendatários da regiāo são especializados em horticultura, 43,0\% cultivam chä e banana e $17,5 \%$ têm apenas um pequeno bananal ou desenvolvem apenas uma agricultura de subsistência. Uma grande proporção dos proprietärios, isto é, 46,0\% deles também desenvolvem apenas uma agricultura de subsistência, 27,0\% especializam se na produção de banana e 16,0\%, na produção de chă. Segundo PASTORE (1974:16), a produção agrícola do vale é hoje a menor do Estado. Sua produtividade é baixa, porém näo o su- 
ficiente para dizermos que todo ele representa apenas uma ărea de baixa renda. Entretanto, a impressão de riqueza ou de prosperidade que algumas de suas grandes propriedades agrícolas possam nos dar parecerá falsa, se considerarmos que a maioria dos seus proprietários são apenas pequenos pro dutores (PEREZ, 1975:133).

Segundo MOL INA FILHO (1977:10), "a extensão gradativa do capitalismo ao campo tende a organizar a produção com vistas à especialização, ao mercado e ao lucro. 0 pa drão de consumo tende a se modificar, pois o camponès passa a vender mais para comprar mais, modificando as caracteristicas básicas de subsistência". No Estado de São Paulo, deví do ao desenvolvimento söcio-econômico de um modo geral, tem havido muitas dessas transformaçōes no setor agricola. Por exemplo, a tecnologia agrícola tem evoluido bastante,tornando a agricultura altamente mecanizada, aumentando a agricul tura comercial. O Vale do Ribeira, entretanto, não tem acompanhado essas transformaçōes, pois nāo ocorrem ali as mudanças drästicas de cultura, nem a mecanizaçāo acelerada das técnicas agricolas que se verifica nas outras regiöes do Estado. Pela Tabela 3 podemos observar alguns indicadores da mecanização agrícola alcançada na área estudada, em seu Esta do e na região Sudeste do país.

Através dessa tabela verificamos que, a ärea estudada apresenta alguns indicadores de mecanização agríco 
TABELA 3. Mecanização Agricola da Região Sudeste, do Estado de São Paulo e do Vale do Ribeira, 1970.

\begin{tabular}{lrcc}
\hline Regiōes & $\begin{array}{l}\text { Nümero de } \\
\text { Tratores }\end{array}$ & $\begin{array}{l}\text { Hectares de } \\
\text { lavoura por } \begin{array}{l}\text { tos estabe- } \\
\text { trator }\end{array}\end{array}$ & $\begin{array}{l}\text { lecimentos } \\
\text { com trator }\end{array}$ \\
\hline Região Sudeste & 79.852 & 121,0 & 5,91 \\
Estado de S.Paulo & 65.801 & 72,5 & 13,63 \\
Vale do Ribeira & 545 & 102,7 & 5,69 \\
\hline
\end{tabular}

FONTE: L.H.PEREZ (1975:55 e 114).

la semelhantes aos de sua região, entretanto encontra-se bas tante atrazada, nesse sentido, em relação ao seu Estado. Por exemplo: hä relativamente pouca diferença, quanto ao nümero de hectares de lavoura por trator, entre o Vale do Ribeira $(102,7$ ha) e a Região Sudeste $(121,0$ ha), enquanto que essa diferença é bem maior entre o Vale do Ribeira e o Estado de São Paulo $(72,5$ ha). Em relação à percentagem de estabele cimentos com trator dă-se o mesmo, isto é, na Região Sudeste e no Vale do Ribeira hä aproximadamente a mesma percentagem $(5,91 \%$ e 5,69\%, respectivamente), enquanto que no Estado de São Paulo, em relação ao Vale do Ribeira, hă mais que o dobro de estabelecimentos com trator $(13,63 \%$ e $5,69 \%$ respecti- 
vamente). Entretanto segundo SIMAOO e GOLDMAN (1958:65), apesar da bananicultura nessa regiāo ser realizada essencialmente através do serviço braçal e de tëcnicas agricolas rudi mentares, nos serviços de plantação, trato e colheita do produto jä têm sido desenvolvidas algumas tarefas bastante especializadas, principalmente na zona da grande rede dos rios que sulcam a região.

Segundo PATRICK (1975b:31), O Vale do Ribeira não conta com um sistema adequado de transportes. Entretanto como vimos, seus principais produtos (chä, banana e produtos horticolas) são pereciveis e, portanto, dependem do transporte rápido para os centros consumidores. Para muitos agricultores, especialmente para os horteläos, frequentemente as despesas com os transportes chega a ser maiores do que as com fertilizantes. No Vale, os parceiros e arrendatärios predominam na agricultura comercial e são eles que mais adotam inovaçōes agricolas (PATRICK, 1975a). Entretanto os custos de produção desses agricultores são bastante elevados, principalmente devido aos gastos com os fertilizan tes para bananas e produtos horticolas e devido aos defensivos caros que o clima da região exige. E por essa razão que os pequenos agricultores (geralmente descendentes de japoneses), só à custa de pesados investimentos e de tecnologia avançada conseguem rendimentos satisfatörios em suas plantaçōes (PEREZ, 1975:133). 
Como temos observado, hä grande variação entre as rendas das familias do Vale. Entretanto, para o presente estudo foram selecionados apenas os agricultores cujas fami lias integram os grupos de baixa renda da região. Entre esses agricultores, muitos inclusive não possuem as escrituras das terras que ocupam e pouco se distinguem dos indios que também habitam a região. Esses agricultores vivem principal mente nas äreas montanhosas e, tal como os indios, também se alimentam com os produtos dos seus roçados primitivos, da caça, da pesca e com a coleta de raizes, vagem e palmito. Em geral a pobreza dos agricultores do Vale os tem levado a trabalhar, também, fora de suas principais unidades de produção $e$, por isso, muitos possuem mais de uma ocupação. E assim que para a maioria dos proprietärios, o arrendamento e a parceria constituem importante fonte de renda e săo eles também que mais recebem renda fora da agricultura. Entretanto, em geral essa renda é bastante pequena, pois não chega a atingir $10 \%$ da renda das familias dos agricultores e, portanto, não contribui substancialmente para a solução dos seus problemas (PATRICK, 1975a:30).

\section{Mão-de-Obra e Aspectos Educacionais}

Na população estudada, não apenas o nível de renda ē baixo mas, o grau de escolaridade tambëm. Os assalariados possuem os graus de escolaridade mais baixos e os pro 
prietärios, os mais elevados. Entretanto, tambëm para os pro prietärios o grau de escolaridade è baixo, pois, em toda a população apenas um chefe de familia tem mais que o curso primärio ( 4 anos) e todos os demais têm apenas esse curso ou menos. Em geral os chefes de familia jä têm idade um tanto avançada e, portanto, o fato deles terem um grau de escolar dade relativamente baixo significa que foi no passado e não no presente, que houve falta de escolas na região. Assim, ē principalmente a idade avançada dos chefes de familia, que atualmente os impede de frequentarem a escola e atë mesmo de receberem ajuda nesse sentido. A Tabela 4 mostra o grau de escolaridade dos agricultores estudados e sua distribuição segundo as categorias de trabalhadores.

Através dessa tabela verificamos que o grau de escolaridade da população estudada é bastante baixo, pois, não vai alèm de 1,3 anos de escola elementar. Verificamos tambēm que, apenas $48,7 \%$ dos assalariados são alfabetizados e, portanto, apesar deles constituirem a grande maioria da população, mais da metade é, ainda, analfabeta. Em relação às demais categorias de agricultores, verificamos que a propor ção de pessoas alfabetizadas tambëm è relativamente baixa. Segundo PATRICK (1975a:20), a alfabetização realizada no lar ou através dos parentes parece ter papel importante entre os agricultores do Vale, uma vez que $56,5 \%$ deles são alfabetiza dos e apenas $42,1 \%$ conseguiram completar, no máximo, o 1 ? 
TABELA 4. Grau de Escolaridade dos Agricultores Entrevistados, segundo as Categorias de Trabalhadores Agríco las, Vale do Ribeira, 1972.

Categorias de

Trabal hadores

Agrícolas
ESCOLARIOADE

anos de escola

a lf abetizados

(\%)

pequenos proprietärios

1,3

65,5

arrendatärios e

parceiros

1,1

67,5

assalariados

1,0

48,7

FONTE: G.F.PATRICK (1975:18).

ano da escola elementar. Isto significa que, entre

es ses

agricultores a educação tem sido bastante valorizada e significa tambèm que, eles têm se esforçado para aprender com os seus familiares, conhecidos ou atravës dos cursos do Mobral.

Como jā observamos, a maioria dos agricultores estudados trabalha, tambëm, fora de suas principais unidades de produção. Entretanto, considerando o trabalho no qual eles dispendem a maior parte do dia, a distribuição da mãode-obra no Vale do Ribeira, segundo o tamanho das propriedades agricolas, $\vec{e}$ a seguinte, conforme mostra a Tabela 5 . 
TABELA 5. Distribuição Percentual da Mão-de-obra Agricola, segundo a Area dos Imöveis Rurais, no Vale do Ribeira, 1972 .

\begin{tabular}{|c|c|c|c|c|}
\hline \multirow{2}{*}{$\begin{array}{l}\text { Área dos } \\
\text { imöveis em } \\
\text { ha }\end{array}$} & \multicolumn{4}{|c|}{ Percentagem da mão-de-obra total } \\
\hline & $\begin{array}{l}\text { assal ariado } \\
\text { permanente. }\end{array}$ & $\begin{array}{l}\text { assa laria- } \\
\text { do temporā } \\
\text { rio. }\end{array}$ & $\begin{array}{l}\text { mão-de- } \\
\text { obra fa } \\
\text { milial. }\end{array}$ & $\begin{array}{l}\text { parceiros e } \\
\text { arrendatä- } \\
\text { rios }\end{array}$ \\
\hline menos de 50 & 13,2 & 41,0 & 43,8 & 2,0 \\
\hline 50 a 500 & 27,7 & 46,5 & 22,3 & 3,5 \\
\hline mais de 500 & 36,3 & 55,9 & 4,7 & 3,1 \\
\hline TOTAL & 21,8 & 45,1 & 30,4 & 2,7 \\
\hline
\end{tabular}

FONTE: L.H.PEREZ (1975:110)

Segundo esta tabela, vemos que na regiāo estü dada predominam os trabalhadores assalariados $(21,8 \%$ e $45,1 \%$ ), pois, constituem $66,9 \%$ do total. Quase a metade dos trabalhadores $(45,1 \%)$ são assalariados temporärios e $30,4 \%$ correspondem à mão-de-obra familial. A proporção de parceiros e arrendatärios è relativamente pequena, pois, è apenas $2,7 \%$ do total. A maior proporção das pequenas propriedades (menos de 50 ha), ou seja $43,8 \%$ delas, caracteriza-se pelo 
uso da mão-de-obra familial, enquanto que $46,5 \%$ das proprie dades mëdias ( 50 a 500 ha) e $55,9 \%$ das grandes (mais de 500 ha), caracterizam-se principalmente pelo emprego de assalariados temporärios.

\section{A Mobilidade Espacial}

Além da mobilidade social, que é objeto especifico deste estudo, também observamos que na região estudada é relativamente intensa a mobilidade espacial dos agricul tores. Essa mobilidade mais frequentemente se realiza em direção às cidades, ou seja, para fora da zona rural. Isto faz com que reste, nas propriedades agrícolas, um nümero considerävel de casas vazias e um nümero bastante reduzido de pes soas ou de familias. Em resumo, è isto o que mostra a Tabe1 a 6 .

Esta tabela apresenta a distribuição das pessoas e familias, e a percentagem das casas vazias existentes nos imóveis rurais do Vale do Ribeira, em 1972. Verificamos que, na região estudada, a percentagem de casas vazias è relativamente grande e aproximadamente a mesma nas propriedades das três classes de äreas consideradas: varia de 22,3\% nas propriedades pequenas (menos de $50 \mathrm{ha}$ ), para $26,4 \%$ nas propriedades médias (50 a 500 ha). O nümero de residentes e de familias, por imóvel, aumenta com o tamanho das proprieda des, variando de 5,6 pessoas e 1,1 familias nas propriedades 
TABELA 6. Distribuição da Ocupação Humana, segundo as classes de Area dos Imóveis Rurais, no Vale do Ribeira, em 1972 .

\begin{tabular}{ccccc}
\hline $\begin{array}{c}\text { Classes de } \\
\text { Area }\end{array}$ & $\begin{array}{c}\text { residentes } \\
\text { por imóvel }\end{array}$ & $\begin{array}{l}\text { \% de casas } \\
\text { desocupadas } \\
\text { nos imóveis }\end{array}$ & $\begin{array}{l}\text { milias en } \\
\text { tre os re } \\
\text { sidentes }\end{array}$ & $\begin{array}{l}\text { familias } \\
\text { vel imó- }\end{array}$ \\
\hline menos de 50 & 5,6 & 22,3 & 38,4 & 1,1 \\
50 a 500 & 9,8 & 26,4 & 18,6 & 2,1 \\
mais de 500 & 24,0 & 22,4 & 4,6 & 5,9 \\
\hline TOTAL & 7,3 & 23,9 & 28,1 & 1,5 \\
\hline
\end{tabular}

FONTE: L.H.PEREZ (1975:113)

pequenas, para 24,0 pessoas e 5,9 familias nas propriedades grandes. Com a percentagem das familias entre os residentes das propriedades dä-se o conträrio, isto è, diminui na medida em que aumenta o tamanho da propriedade, pois varia de $4,6 \%$ nas propriedades grandes, para $38,4 \%$ nas propriedades pequenas.

Esta tabela mostra ainda que, è relativamente pequeno o nümero de pessoas e de familias residentes nas 
propriedades do Vale, ou seja, hä apenas 7,3 residentes e apenas 1,5 familias, em mëdia, por imövel. Segundo PATRICK (1975a), é esta a situação do Vale e geralmente são os agricultores mais jovens que abandonam a região, atraídos pelos empregos ou pelas cidades. A existência de cidades como são Paulo e Santos, relativamente pröximas, chega a fazer com que na ēpoca das safras a mão-de-obra se torne escassa na região. Entretanto, a saida de agricultores do Vale tem sido compensada pela chegada de imigrantes vindos principalmente do nordeste do país. Assim è que, mais de 45,0\% das pessoas residentes no Vale, para ali imigraram vindo de outras regiões: 45,0\% vieram do nordeste e $28,0 \%$ vieram do sul do pais; $24,0 \%$ vieram de outras regiōes do pröprio Estado e apenas $3,0 \%$ são estrangeiros. Consequentemente è relativamen te grande a mobilidade espacial dos agricultores na região. 


\section{MOBILIDADE E TRABALHO DOS AGRICULTORES}

1. A Hierarquia de Prestigio Ocupacional

Säo vários os fatores que servem de base ao prestígio, ou são vários os critérios que a sociedade e os individuos usam para atribuir prestigio às pessoas. Entretan to, tomando-se a sociedade como um todo, o prestigio das pes soas tem sido definido principalmente em funçāo de sua parti cipaçāo nas principals instituiçōes, como por exemplo nas instituiçōes econōmica, politica e educacional. Assim é que, considerando-se a sociedade como um todo e esses critérios de prestigio, observa-se um claro desprestigio do rural em relação ao urbano, pois, geralmente è no setor rural onde en contramos os niveis de vida mais baixos da populaçäo. Entretanto o setor rural representa uma camada bastante numerosa 
e diversificada da população e, assim, podemos encontrar entre os agricultores uma clara diferenciação ou estratificaçăo social, baseada principalmente nas diferenças quanto aos niveis de vida e quanto ao prestígio resultante das värias categorias de trabalhadores.

Ho setor agrícola, os sistemas de exploração do solo, os tipos de cultura, a natureza dos povoamentos e outros fatores levam à formação de diversas categorias de trabalhadores, os quais desenvolvem diferentes relaçōes de trabalho. A complexidade da estrutura ocupacional dai resultante, depende essencialmente das categorias desses trabalha dores e das diferentes formas de exploração do solo. Considerando-se que as ocupaçōes agricolas podem ser exercidas sob vārias condiçōes e que pode haver muita semelhança entre elas, verifica-se que è dificil diferenciar e classificar, com exatidāo, os vários tipos de trabalhadores agrícolas ou as suas värias ocupaçōes. Na presente pesquisa, com base nos estudos da Fundação Getūilio Vargas (1956), nos estudos de ETTORI (1961), nas observaçōes de PATRICK (1975a) e nos dados coletados, foram definidas cinco categorias de trabalhadores agrícolas, em função das quais foram classificados os agricultores estudados. Essas categorias são as dos (1) peque nos proprietärios, (2) arrendatärios, (3) parceiros, (4) assalariados fixos e (5) assalariados eventuais, e se referem essencialmente às diferenças nas condições de trabalho, nos. 
níveis de vida e no poder de decisão dos agricultores.

Como podemos perceber, essas categorias distin guem entre proprietários e não-proprietários, isto é, entre os proprietärios agricolas e as demais categorias de trabaIhadores rurais. Segundo os estudos da Fundação Getülio Vargas (1956:71), trata-se de uma distinção entre dois grupos fundamentais, uma vez que a posse da terra è um dos principais determinantes do nivel de vida dos agricultores. Na categoria dos proprietărios incluimos todos os agricultores que trabalham em suas pröprias terras. Em geral eles possuem uma sltuação almejada por quase todos os outros agricultores, pois sāo donos do seu pröprio quinhão $e$, salvo casos especiais, têm um nivel de vida superior ao dos outros agricultores que não alcançaram a condição de proprietărio. Segundo MARSHALL (1963:571), a posição desses pequenos proprietários tem grandes atrativos, pois eles são livres para fazer o que quiserem, não são perturbados pela interferência do senhorio nem pelo receio de que outra pessoa colha os frutos de sua labuta. O sentimento de propriedade tende a dar-lhes mais respeito próprio. Raramente eles estão ociosos ou consideram seu trabalho como mera servidão; ao conträrio, fazem tudo pe la terra que tanto amam.

o segundo grande grupo de agricultores estudados refere-se aos não-proprietärios, ou seja, aos arrendatários, parceiros e à numerosa classe dos empregados rurais.E $\underline{s}$ 
tes sāo os assalariados em dinheiro elou produtos, os quais foram agrupados em duas categorias, relativas às suas condições de trabalho: a categoria dos assalariados fixos e a dos assalariados eventuais.

A categoria dos arrendatários refere-se ao gru po dos agricultores que não trabalham em suas pröprias terras e pagam um arrendamento ou um aluguel fixo pelo uso das propriedades onde fazem suas exploraçōes agricolas. Em geral - valor desse aluguel è previamente combinado entre as partes contratantes, ou seja, entre o arrendatário e o proprietärio e pode ser pago em dinheiro elou em espécie.

Tal como os arrendatários, os parceiros tambĕm correspondem a uma categoria de trabalhadores agricolas que pagam aluguel pelo uso das terras onde fazem suas exploraçōes. Diferindo dos arrendatários, entretanto, o aluguel pago pelos parceiros não corresponde a uma quantia fixa mas, a uma quota-parte da produção por eles obtida nas propriedades alugadas. Geralmente esta quota-parte também è previamente combinada entre as partes contratantes, ou seja, entre - parceiro e o proprietário e comumente é paga em espécie. Nos estudos sobre a parceria agrícola não raro encontramos uma diferenciação entre parceiros autônomos e não-autônomos. são considerados parceiros autônomos os que se assemelham aos arrendatários no sentido de que, tambēm eles pagam um aluguel (embora variävel em função do volume da produção)pela 
terra que usam e têm autonomia na administração de suas exploraçōes agrícolas. No outro caso, além do proprietário interferir bastante na administração ou nas decisões relativas às exploraçōes agrícolas do parceiro, fornece-l he sementes, adubo, ferramentas, etc. para o seu trabalho. Daí a razão dessa parceria ser considerada não-autônoma. Segundo os estú dos da Fundação Getūlio Vargas (1956:73), este tipo de parce ria se assemelha ao caso dos empregados agrícolas, especialmente ao dos assalariados em espécie, com a diferença de que, no caso dos parceiros, a remuneração corresponde a uma fraçäo de sua produção. Segundo esses estudos a classificação dos parceiros não-autónomos estă merecendo uma revisão,pois, a denominação parceria deveria ser reservada apenas para o caso dos parceiros autónomos, isto é, para os que se assemeIham aos arrendatărios. Os parceiros näo-autônomos deveriam ser classificados na categoria dos empregados rurais. Foi e te o critério que adotamos na classificação dos agricultores estudados.

A grande maioria dos empregados rurais trabaI ham como diarista, mensalista ou parceiro nāo-autōnomo. Segundo os estudos de ETTORI (1961:17) sobre os trabalhadores agrícolas no Estado de São Paulo, os agricultores diaristas e mensalistas sāo, respectivamente, os que prestam serviços na base de uma remuneraçāo diāria ou mensal, recebendo seus salärios em dinheiro no final de cada mès, quinzena ou mesmo 
semanalmente. Eles também podem receber, a seu pedido, adian tamentos em dinheiro ou em mercadorias que säo adquiridas na pröpria fazenda, ou nos armazens das vilas ou cidades prö ximas, onde a fazenda mantenha uma conta aberta. As relaçöes de trabalho entre esses empregados e seus patröes diferem de uma propriedade para outra. Em todas elas entretanto, eles tendem a ser trabalhadores não especializados, nāo têm dirẹ to de tomar decisões sobre seus serviços e limitam-se a exe cutar as tarefas especificas que lhes sāo indicadas. Segundo ETTORI, os diaristas, mensalistas e parceiros nāo-autônomos constituem a grande maioria dos trabalhadores assalariados. em dinheiro e/ou em espécie, na agricultura. Geralmente as propriedades os mantèm para os serviços permanentes durante - ano inteiro (o que dá origem à categoria dos assalariados fixos), ou apenas os contratam para as tarefas temporárias ou de curta duraçāo (o que dá origem à categoria dos assalariados eventuais). Segundo os estudos do Comité Interamerica no de Desenvolvimento Agricola (1966:146), dentre os trabalhadores agrícolas, os assalariados fixos e eventuais sāo os mais desprotegidos e representam uma grande proporção dos trabalhadores agricolas do Brasil. Na presente pesquisa todos os agricultores diaristas, mensalistas, parceiros nāo-au tônomos e, enfim, todos os agricultores que integram o grande grupo dos empregados rurais, foram classificados apenas nessas duas categorias, ou seja, como assalariados fixos ou 
eventuais.

A categoria dos assalariados fixos compreende todos os empregados diaristas e mensalistas que, alèm da remuneração em dinheiro, raramente recebem em espécie, a não ser nos casos em que também recebem da fazenda mercadorias e lenha para combustível. Também foram incluidos, na categoria do pessoal fixo das fazendas, todos os empregados que têm uma remuneraçāo mista, isto $\vec{e}$, que alèm de receberem uma par te do salärio em dinheiro, tèm permissão para cultivar, na propriedade, pequenas roças de produção particular ou de sub sistēncia, as quais são consideradas parte de suas remunera çöes. Finalmente, também foram incluidos na categoria dos assalariados fixos os parceiros não-autōnomos, isto è, os trabalhadores das fazendas que recebem uma quota-parte de sua produção em produto ou em espécie. Eles podem ser total ou parcialmente assalariados e recebem das fazendas um pedaço de terra para plantarem para sua subsistência e para vender. Em geral esses parceiros têm certa liberdade para decidirem o que e quanto devem plantar, entretanto, em muitos ca sos essa liberdade é mais aparente do que real. Não raro é o proprietário da terra que designa qual a ärea a ser plantada, o que e quando deve ser plantado. Ao disporem de sua pro dução, esses parceiros devem entregar ao proprietärio uma parte dos produtos ou devem vender-lhe toda sua parte vendável. Esse tipo de parceria e os trabalhadores com lotes,mais frequentemente foram encontrados nas fazendas mais antigas e 
correspondem aos trabalhadores agricolas mais tradicionais da região.

Na categoria dos assalariados eventuais foram incluidos os trabalhadores agrícolas que declararam ser admitidos, mais frequentemente, apenas por ocasião das grandes colheitas e plantios, ou para as tarefas de curta duração findas as quais são dispensados. Eles se constituem numa mão-de-obra erradia e, segundo os estudos da Fundação Getülio Vargas (1956:75), representam uma categoria do nível mais baixo do meio rural brasileiro. A instabilidade dos seus empregos chega a dificultar inclusive a constituição de suas familias. Quando residem fora das propriedades em que trabalham, ou seja, quando moram na zona urbana, vilas e subưrbios e vêm à propriedade apenas para prestarem serviços em certas épocas do ano, esses trabalhadores são chamados "volantes". Sua remuneraçāo e a remuneração dos assalariados eventuais tende a ser quase exclusivamente em dinheiro e geralmente è estabelecida por dia, por hora ou por tarefa executada. Muito frequentemente a diäria desses trabalhadores tende a ser superior à dos trabalhadores permanentes das fazendas, mas nem por isso o volume total de suas rendas chega a ser superior ao dos trabalhadores fixos.

Dadas as diferentes condiçōes de trabalho que expressam, essas categorias constituem-se em categorias de mão-de-obra ou de trabalhadores agrícolas. Essencialmente 
elas expressam as diferentes formas de relaçōes de trabalho existentes entre a mäo-de-obra rural e os empresärios agríco las e refletem os diferentes niveis ou condiçōes de vida de vida dos agricultores. A classificação dos agricultores estú dados através dessas categorias, resultou na seguinte distribuição, conforme mostra a Tabela 7 .

TABELA 7. Frequência e Percentagem dos Agricultores Entrevis tados, segundo as Categorias de Trabalhadores Agri colas, Vale do Ribeira, 1973.

\begin{tabular}{lcc}
$\begin{array}{lc}\text { Categorias de trabalhadores } \\
\text { agricolas }\end{array}$ & Frequência & $\%$ \\
\hline proprietärio & 52 & 28,3 \\
assalariado fixo & 49 & 26,6 \\
assalariado eventual & 41 & 22,3 \\
arrendatärio & 24 & 13,0 \\
parceiro & 18 & 9,8 \\
\hline TOTAL & 184 & 100,0 \\
\hline
\end{tabular}

Esta tabela mostra a distribulção dos agricultores estudados, segundo as categorias de trabalhadores agr colas, as quais representam os estratos da estrutura ocupa- 
cional relativa à população estudada. Como vemos, a categoria de maior volume è a dos proprietärios, pois constitui $28,3 \%$ do total. Entretanto, se agruparmos os assalariados fi xos e eventuais (excluindo-se apenas as categorias dos parceiros e a dos arrendatários) numa única categoria, isto $\bar{e}$, na dos empregados agrícolas, veremos que ela passa a ser a de maior volume na população, pois se constitui em $48,9 \%$ do total. Segundo os estudos do Comité Interamericano de Desenvolvimento Agrícola (1966), as proporçōes dessas categorias podem variar nas diferentes regiöes do Brasil. Entretanto, muito provavelmente em nenhuma regiäo elas deixam de estar representadas. E isto o que acontece tambëm na região estudada. Os resultados da Tabela 7 coincidem ainda com os da Secretaria de Agricultura do Estado de São Paulo, apresentados por ETTORI (1961), relativos à força de trabalho na zona rural de todo o Estado. Segundo estes resultados (verificar Apêndice 9), a categoria dos proprietärios è de fato a de maior volume na populaçāo, pois constitui $26,4 \%$ do total. E se tambëm ali agruparmos as categorias dos colonos, dos cama radas por dia e camaradas por mès lexcluindo-se também apenas as categorias dos parceiros e a dos arrendatários) numa única categorla, ou seja, na dos empregados agricolas, verificaremos, também, que esse estrato è o de maior volume na populaçäo, pois se constitul em $42,2 \%$ do total.

Segundo HALLER et alii (1972:942), as pesqui- 
sas sobre a mobilidade social requerem o conhecimento dos sistemas de prestígio da sociedade onde a mobilidade ocorre. Segundo PATRICK (1975a:12), na região estudada as categorias acima definidas podem se constituir numa hierarquia de prestígio, uma vez que nelas as posiçōes têm sido conquistadas apenas quando as pessoas jă têm adquirido um certo nível de idade, de experiência elou de recursos. Assim è que, na regiāo estudada, a média das idades dos assalariados e dos par ceiros é apenas 38 e 40 anos respectivamente, enquanto que a dos proprietários é 53 anos. Cerca de $50,0 \%$ dos assalariados e 40,0\% dos parceiros têm menos de 38 anos, enquarito que apenas $10,0 \%$ dos proprietärios têm menos que essa idade. Assim, podemos concluir que as categorias definidas se constituem numa "agricultural ladder", uma vez que, nelas, as pessoas tèm conseguido alcançar as posiçōes mais prestigiadas apenas na medida em que avançam em idade, experiencia, etc. Dai a razão das idades das pessoas aumentarem, na medida em que passamos das categorias de menos prestigio para as mais prestigiadas, ou na medida em que passamos das categorias mais do fundo para as do topo dessa "escada agricola". Nesta pesquisa, procurando definir melhor essa hierarquia de prestígio, pedimos a 63 agricultores da região estudada que considerassem os nfreis de vida, as condiçōes de trabalho $e$ o prestígio dos agricultores pertencentes a cada uma das categorias de trabalhadores definidas e as classificassem segun- 
do uma hierarquia de prestígio. Os resultados desses julgamentos são apresentados na Tabela 8 .

Esta tabela apresenta a distribuiçāo dos julga mentos dos agricultores quanto ao prestigio das catogorias consideradas. A concentraçāo das maiores percentagens, na diagonal da tabela, mostra que mais frequentemente os niveis mais altos de prestígio, isto é, os nivels 1,2 e 3 foram atribuidos às categorias dos proprietários, arrendatários e parceiros, respectivamente; os niveis mais baixos, isto é, 4 e 5 mais frequentemente foram atribuidos às categorias dos assalariados fixos e assalariados eventuais, respectivamente. A dispersāo das percentagens em relaçāo à diagonal da tabela mostra que houve mais acordo entre os agricultores, quanto ao prestígio atribuido às categorias dos proprietários e dos assalariados eventuais, do que quanto às demais categorias. Segundo os estudos de HALLER et alii (1972). realizados em Açucena (Minas Gerais) e em Bezerros (Pernambu co), mesmo nas comunidades rurais mais tradicionais e isoladas, mesmo naquelas onde predomina apenas uma agricultura de subsistência, hä uma estratificaçāo ou uma diferenciaçāo social, que é reconhecida pelos moradores locais em termos de seus julgamentos sobre as ocupaçōes. E isto o que demonstra a Tabela 8 em relaçāo à populaçāo estudada. Seus resultados indicam que os agricultores entrevistados tinham uma clara definiçāo das categorlas que lhes foram apresentadas, ou se- 
TABELA 8. Distribuiçāo Percentual dos Julgamentos dos Agricultores Entrevistados, quanto ao Prestígio atribuido às Categorias de Trabalhadores Agrícolas. Vale do Ribeira, 1977

\begin{tabular}{|c|c|c|c|c|c|}
\hline \multirow{4}{*}{$\begin{array}{l}\text { Míveis } \\
\text { de } \\
\text { Prestí } \\
\text { gio }\end{array}$} & \multicolumn{2}{|r|}{ CATEGORIAS } & \multicolumn{2}{|c|}{ DE TRABALHADORES } & AGRTCOLAS \\
\hline & proprie- & arprenda- & parcei- & assalaria & assala- \\
\hline & tário & tärio & ro & do $f i \times 0$ & riado \\
\hline & $g$ & $q$ & $\%$ & & $\underset{\%}{\text { eventual }}$ \\
\hline 1 & 90,5 & 1,6 & 0 & 7,9 & 0 \\
\hline 2 & 3,2 & 68,9 & 14,8 & 15,9 & 0 \\
\hline 3 & 1,6 & 24,6 & 49,2 & 23,8 & 9,5 \\
\hline 4 & 4,7 & 0 & 34,4 & 46,0 & 14,3 \\
\hline 5 & 0 & 4,9 & 1,5 & 6,4 & 76,2 \\
\hline \multirow[t]{2}{*}{ TOTAL } & 100,0 & 100,0 & 100,0 & 100,0 & 100,0 \\
\hline & $(63)$ & $(61)$ & $(61)$ & $(63)$ & $(63)$ \\
\hline
\end{tabular}

ja, eles sabiam perfeitamente o que elas significavam e quais eram os seus valores em termos de prestígio na população. Os resultados dessa tabela indicam que, o grupo de referência em funçäo do qual os agricultores julgaram o prestígio das categorias, de un modo geral é constituido pelos agricultores de toda a regiāo, o que significa que a hierarquia definida mui- 
to provavelmente faz parte da realidade social da maioria desses agricultores. Os valores que os agricultores entrevistados mais frequentemente consideraram, para julgar o prestigio das categorias, referem-se ao fato de seus respectivos trabalhadores possuirem ou não a propriedade da terra, serem ou não trabalhadores livres e independentes e terem ou não um trabalho ou um emprego "fixo e garantido". Foi princi palmente em função desses valores que os entrevistados definiram a hierarquia de prestígio encontrada. Como vimos, segun do essa hierarquia as posiçōes mais elevadas ou de mais pres tígio são ocupadas pelos proprietärios de terra ou pelos tra balhadores independentes; as posiçōes mais baixas ou de menos prestígio são ocupadas pelos trabalhadores subordinados ou pelos assalariados fixos e eventuais. Consequentemente, da da essa hierarquia, realizar uma mobilidade social ascendente significa mudar de uma dessas categorias de menos prest gio para outra mais prestigiada e vice-versa.

Na sociedade contemporânea muitas posiçöés sociais säo adquiridas e outras atribuidas. E isto tambèm o que se verlfica na população estudada, considerando-se o conjunto dos valores e a estrutura de prestigio definida pelos agricultores. Segundo HILL e CHRISTENSEN (1942), essas diferentes formas de definição da posição das pessoas representa uma incongruência da estrutura social e contribui para que os individuos tenham diferentes chances de mobilidade. 
E por essas razöes que, tambēm na populaçäo estudada, vamos encontrar muitos agricultores que se esforçaram para conquí tar suas posiçōes, enquanto que outros apenas se acomodaram nas posiçōes adquiridas pelos seus pais.

São värias as ocupaçōes em relação às quais nāo hä correspondência entre o grau de prestígio e o volume de renda que elas representam. E o que se verifica também em relaçäo às categorias de trabalhadores encontradas, conforme demonstram os dados da Tabela 9, quando comparados com os da Tabela 8 .

A Tabela 9 mostra a distribuiçäo percentual dos agricultores entrevistados, segundo a receita mensal de suas familias e as categorias de agricultores. Verifica-se que as familias que têm receita maior sāo as dos proprietärios, pois $62,6 \%$ delas recebem mais de Cr $\$ 4,000,00$ por mes. As que têm receita menor sāo as dos assalariados eventuais, pois $71,5 \%$ delas recebem menos de Cr\$3.000,00 por mes. Entretanto a grande maioria $(75,8 \%)$ das familias dos assalaria dos fixos recebe mais de Cr $\$ 3.000,00$ por mes, enquanto que a maioria das familias dos parceiros $(70,0 \%)$ e dos arrendatá rios $(77,8 \%)$, e $25,0 \%$ das familias dos proprietārios, têm uma receita de apenas Cr\$3.000,00 ou menos por mes. Dada a hierarquia de prestígio encontrada, vemos entāo que nem sempre hä relação entre o prestígio da categoria e a receita das familias dos agricultores, pois as categorias dos proprietá- 
TABELA 9. Distribuição Percentual dos Agricultores Entrevistados, segundo a Receita Mensal de suas familias e as Categorias de Trabalhadores Agrícolas, Vale do Ribeira, 1973.

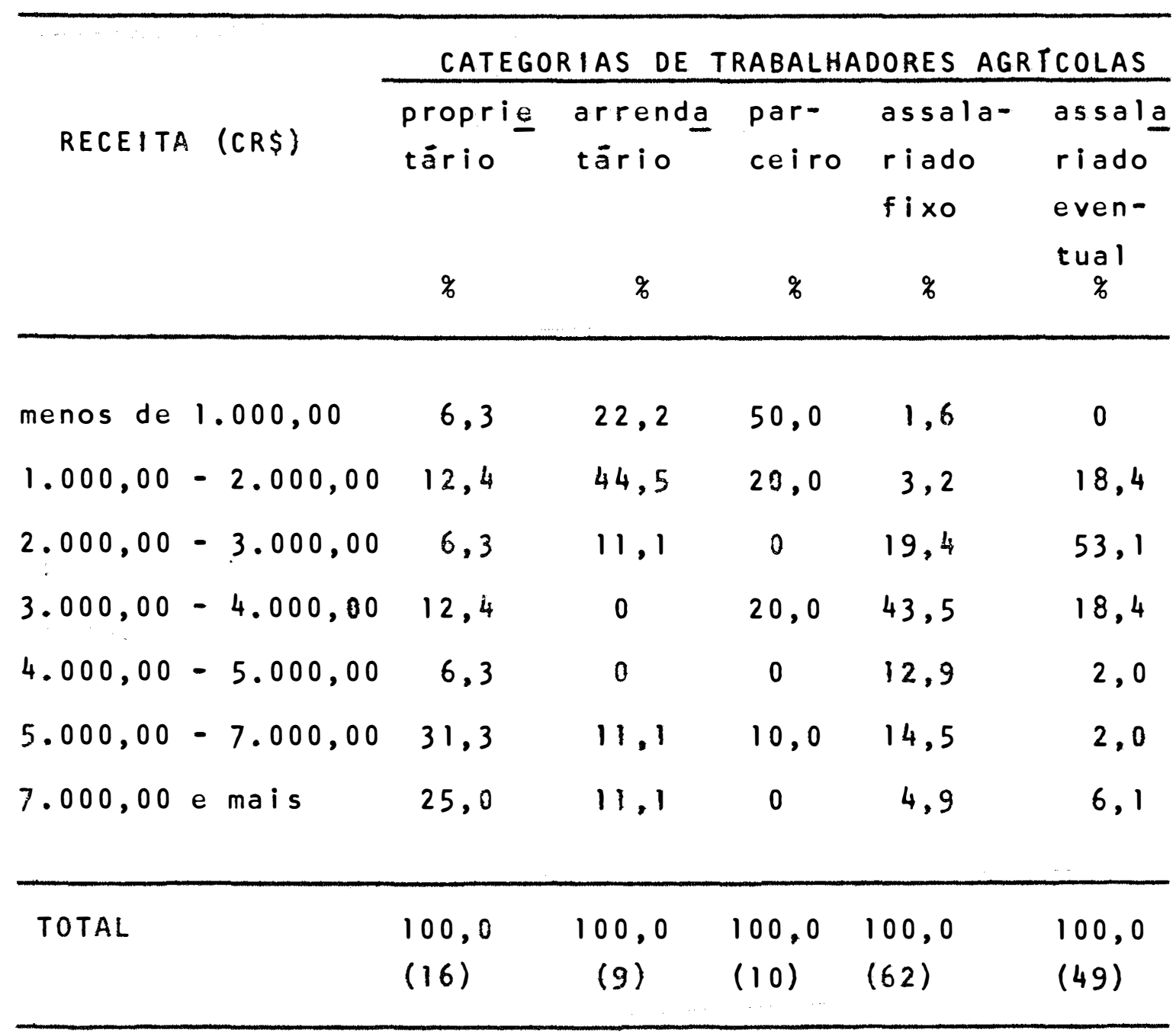

rios, arrendatários e parceiros foram consideradas superiores, em prestígio, à categoria dos assalariados fixos. De fa to, na regiäo estudada muitos pequenos proprietários, arren- 
datärtos e parceiros desenvolvem apenas uma agricultura de subsistência, estāo fora da agricultura comercial. A renda de suas familias frequentemente excede a receita,entretanto, frequentemente também, elas nem conseguem traduzir em volumes de renda os seus parcos rendimentos. Hä inclusive muitas familias de pequenos proprietärios, cuja boa parte da renda advem de pensão recebida pelas pessoas idosas aposentadas da indústria ou do funcionalismo püblico (PATRICK, 1975b:22). Para essas familias, então, a renda provinda da agricultura pode ser secundária. Isto não as estimula a se modernizar co mo agricultores, apesar de seu prestígio vir essencialmente de sua posiçāo na categoria dos proprietários agricolas. Ape sar disto, como vimos, os trabalhadores sem terra ou os assalariados foram considerados como tendo menos prestigio que os proprietários, arrendatários e parceiros. Segundo simAo e GOLDMAr (1958:82), de fato, mesmo "os pequenos posseiros, na em que nāo vendem sua força de trabalho, ocupam posiçōes superiores à dos que se entregam a serviço de terceiros.Multos tendem a se nivelar com estes, na medida em que se assalariam".

Na população estudada, por exemplo, dada a hie rarquia de prestigio encontrada, os agricultores que passaram das categorias dos proprietärios, arrendatários ou parceiros para a dos assalariados fixos, realizaram uma mobilidade descendente. Entretanto, muitas pessoas podem näo consi 
derar assim. Na região estudada, como vimos, hä muitos proprietärios, arrendatärios e parceiros cuja receita familiar mensal é menor e mais incerta que a de muitos assalariados fixos. Assim, para muitas pessoas o fato de um desses proprietários ter se tornado um desses assalariados fixos, não necessariamente significa uma mobilidade descendente. Elas podem valorizar mais os rendimentos econômicos desse agricul tor, como assalariado fixo, antes que suas condiçōes anterio res, como proprietärio.

\section{A Mobilidade Social dos Agricultores}

Os estudos sobre mobilidade de um modo geral têm demonstrado que, mais frequentemente os filhos seguem as ocupaçōes dos pais e, segundo DUNCAN (1966:68), è na agricultura que estão os exemplos mais extremos desse processo. De fato, PIHLBLAo e GREGORY $(1957: 44)$ em seus estudos tambëm verificaram que, a grande maioria dos agricultores eram fiIhos de agricultores. Foi no sentido de verificar esse processo na população estudada, que classificamos os agricultores entrevistados e os seus pais nas seguintes amplas categorias de agricultores: 1) proprietārios 2) arrendatärios'e parceiros e 3) assalariados. Consideramos essas tres categorias bastante distintas e significativas no processo estudado, uma vez que elas permitem distinguir claramente entre proprietärios, não proprietärios ou assalariados e entre es- 
ses e os co-responsáveis pela exploração agrícola, que säo os arrendatärios e parceiros. Foi em função dessa classifica ção que obtivemos os resultados da Tabela 10.

TABELA 10. Distribuição Percentual dos Agricultores Entrevi $\underline{s}$ tados e de seus Pais, segundo as Categorias de Trabalhadores Agricolas (amplas categorias), Vale do Ribeira, 1973.

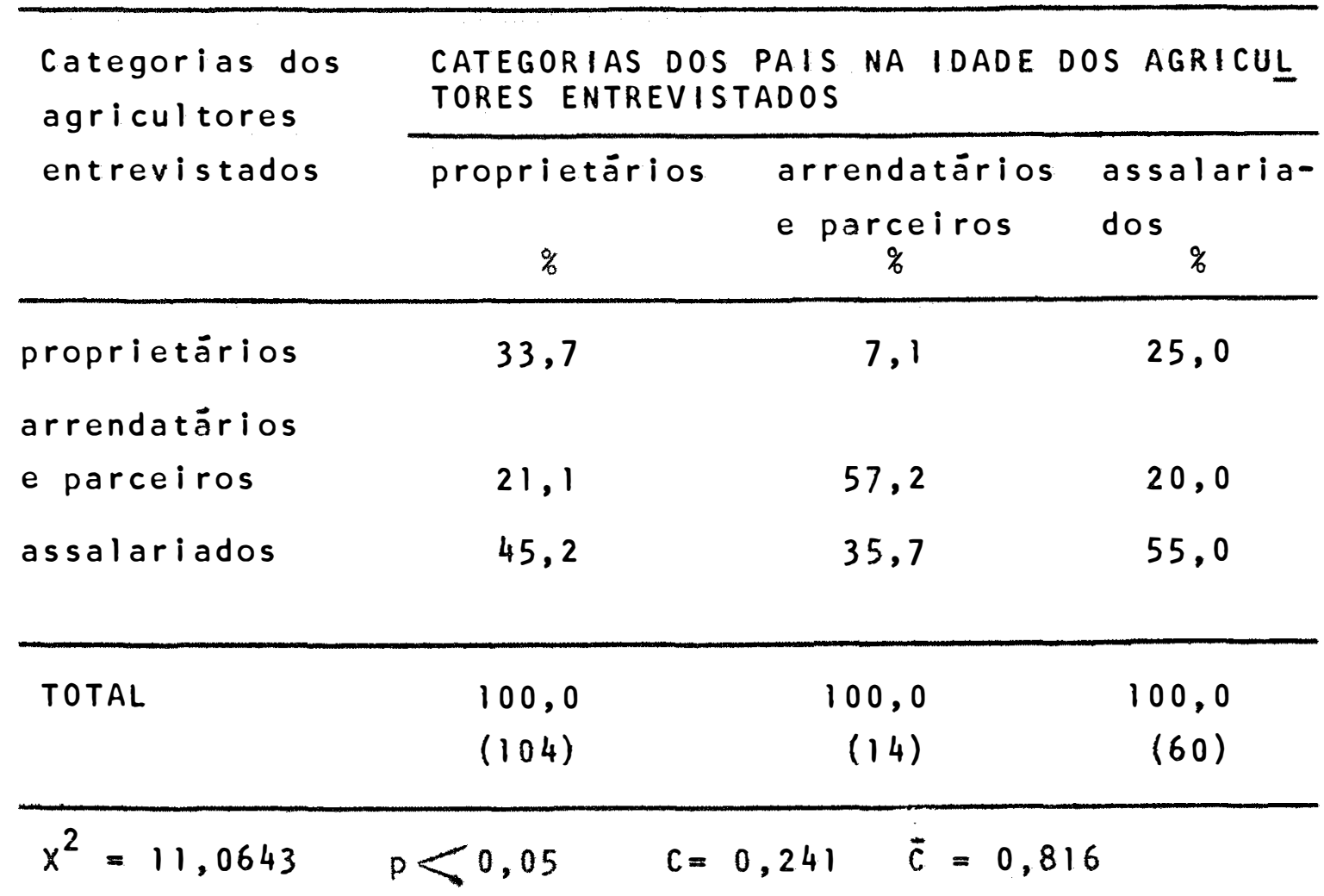

Essa tabela mostra a classificação dos agricul tores estudados e de seus pais, segundo as tres amplas categorias consideradas. Através dela vemos que hă associação en 
tre as categorias dos pais e dos filhos uma vez que,mais da metade dos filhos dos assalariados $(55,0 \%)$, dos filhos dos parceiros e arrendatários $(57,2 \%)$ e $33,7 \%$ dos filhos dos pro prietărios, se mantêm nas mesmas categorias de seus pais.Por tanto, segundo esse grau de especificação das categorias dos agricultores, observa-se uma relativa imobilidade na estrutú ra ocupacional da população estudada, pois, em ültima anālise, também verificamos que todos os seus agricultores sāo filhos de agricultores. Em consequência, nāo houve realmente mobilidade social num grau significativo na população estudada e, portanto, todo o movimento e a alta mobilidade espacial, que atualmente se verifica na regiāo, nāo deve deixarnos a falsa impressāo de que nāo existe uma grande imobilida de em sua estrutura ocupacional.

Consequentemente a Tabela 10 mostra que, apesar dos agricultores mudarem frequentemente de emprego ou de ocupaçäo, sempre continuou existindo entre eles e seus pais uma certa herança ocupacional e, assim, tambëm uma herança do nivel de vida ou da pobreza que os agricultores de baixa renda deixam para os seus filhos. De fato, segundo Broom e SELZNICK (1963:204-216), na zona rural, embora os filhos pos sam mudar muitas vezes de ocupaçāo, geralmente essas mudanças ocorrem apenas entre atividades específicas de uma mesma categoria ocupacional, ou eles mudam apenas para categorias adjacentes àquelas de seus pais. Assim, vemos que as ca 
tegorias dos pais limitam os horizontes ou as alternativas nas escolhas ocupacionais dos filhos, fazendo com que geralmente eles escolham as mesmas ocupações ou ocupaçōes semeIhantes às de seus pais.

Portanto hã, tambēm na população estudada, uma clara tendència dos filhos permanecerem nas mesmas categorias de agricultores dos seus pais, pois a maioria deles ten de a adquirir um tipo de trabalho ou de ocupação que tem um grau de prestígio e inclusive um volume de renda semelhante àquele de seus pais. São värios os fatores que contribuem pa ra isso. Entretanto o principal deles é que, em relação ao nível social ou ao grau de prestígio, a familia funciona co mo uma unidade, pois todos os seus membros tendem a ser reco nhecidos como tendo o mesmo nivel de vida e de prestígio do seu chefe (SMITH, 1966:155).

Entretanto, vemos que não é forte a associação entre as categorias dos agricultores e de seus pais demonstrada na Tabela 10. As categorias consideradas são excessiva mente amplas e, assim, podem estar escondendo a mobilidade que dentro delas ocorre. Por outro lado, apesar do nível de significância (menos de 0,05$)$ garantir certa representatividade da amostra utilizada, o indice de associação encontrado é relativamente baixo, ou seja, é apenas 0,241 quando poderia ser até 0,816 (Coeficiente de Contingência de Pearson). Consequentemente podemos supor que, existe alguma mobilida 
de social entre os agricultores estudados e seus pais. De fá to, foi isto o que verificamos atravès da Tabela 11.

TABELA 11. Distribuição Percentual dos Agricultores Entrevís tados e de seus Pais, segundo as Categorias de Trabalhadores Agricolas, Vale do Ribeira, 1973.

\begin{tabular}{|c|c|c|c|c|c|}
\hline \multirow{2}{*}{$\begin{array}{l}\text { Categorias } \\
\text { dos Agricul } \\
\text { tores entre } \\
\text { vistados }\end{array}$} & \multicolumn{5}{|c|}{$\begin{array}{l}\text { CATEGORIAS DOS PAIS NA IDADE DOS AGRICUL- } \\
\text { TORES ENTREVISTADOS }\end{array}$} \\
\hline & $\begin{array}{c}\text { proprie } \\
\text { tärio } \\
\%\end{array}$ & $\begin{array}{c}\text { arrenda } \\
\text { tärio } \\
\%\end{array}$ & $\begin{array}{c}\text { parce! } \\
\text { ro } \\
\%\end{array}$ & $\begin{array}{c}\text { assala } \\
\text { riado } \\
\text { fixo } \\
\%\end{array}$ & $\begin{array}{l}\text { assalaria } \\
\text { do even- } \\
\text { tual } \\
\%\end{array}$ \\
\hline proprietärio & 33,7 & 0 & 50,0 & 25,7 & 24,0 \\
\hline arrendatärio & 11,5 & 41,6 & 0 & 14,3 & 8,0 \\
\hline parceiro & 9,6 & 25,0 & 0 & 5,7 & 12,0 \\
\hline $\begin{array}{l}\text { assalariado } \\
\text { fixo }\end{array}$ & 27,9 & 16,7 & 50,0 & 25,7 & 24,0 \\
\hline $\begin{array}{l}\text { assalariado } \\
\text { eventual }\end{array}$ & 17,3 & 16,7 & 0 & 28,6 & 32,0 \\
\hline TOTAL & $\begin{array}{l}100,0 \\
(104)\end{array}$ & $\begin{array}{l}100,0 \\
(12)\end{array}$ & $\begin{array}{l}100,0 \\
(2)\end{array}$ & $\begin{array}{l}100,0 \\
(35)\end{array}$ & $\begin{array}{l}100,0 \\
(25)\end{array}$ \\
\hline
\end{tabular}

Esta tabela demonstra, de modo mais especifico que a anterior, as relações entre as categorias de trabalha 
dores agricolas relativas aos agricultores estudados e aos seus pais. Esta é a chamada "matriz de mobilidade" e,segundo - $x^{2}$ para ela calculado, não há associaçāo entre as suas categorias ao nivel de significância de 105 . Em consequência esses resultados demonstram que, dado este grau de especificaçāo das categorias, mais frequentemente houve mobilidade social dos agricultores estudados em relaçäo a seus pais. Se gundo esta matriz, em todas as categorias sempre foi menor o número de agricultores que permaneceram nas mesmas categorias de seus pais. Em relaçāo aos proprietários e arrendatários, por exemplo, a maioria dos entrevistados $(66,3 \%$ e $58,4 \%$ respectivamente) desceu para categorias inferiores enquanto que, em relaçāo aos assalariados fixos e eventuais, $45,7 \%$ e $68,0 \%$ respectivamente, subiram para categorias mais valorizadas que as de seus pais.

A Tabela 11, mostra, portanto, as proporçōes e direçōes em que se verifica a mobilidade social entre os pais e os filhos estudados. Quanto aos filhos dos proprietá rios, vemos que apenas 1,7 em cada 5 deles continuou na mesma categoria dos pais, ou, apenas $33,7 \%$ deles continuaram sendo proprietários; os demais desceram para categorias menos prestigiadas. Quanto aos filhos dos arrendatários, apenas 2,1 em cada 5 deles permaneceram na mesma categoria dos pais, ou, apenas $41,6 \%$ deles continuaram sendo arrendatários; os demais também desceram para categorias menos prestigia 
das. Em consequência verificamos que, é relativamente grande a mobilidade existente mesmo nas categorias mais altas da estrutura ocupacional e, dada essa localização, há mais chan ces dela ocorrer em direçäo ao fundo dessa estrutura.

Quanto às categorias do fundo da estrutura ocu pacional verificamos que, dentre os filhos dos assalariados fixos, cerca de $1 / 4$ continuou na mesma categoria de seus pais, 1/4 tornou-se proprietário e 1/5 subiu para as catego rias dos arrendatários e parceiros. Entretanto, $1 / 4$ dos filhos dos assalariados fixos desceram para a categoria dos assalariados eventuais, o que demonstra que a tendencia em descer para essa categoria foi, também, bastante significati va. Quanto aos filhos dos assalariados eventuais, apenas $1 / 3$ permaneceu na mesma categoria de seus pais, $1 / 4$ tornou-se as salariado fixo, enquanto que a grande maioria, isto é, quase a metade deles, subiu para as categorias dos proprietários, arrendatärios e parceiros. Portanto, considerando a Tabela 11 , vemos que a tendencia em permanecer nas categorias dos pais foi bem menor entre as categorias do fundo do que entre as do topo da estrutura ocupacional. Apenas $66,3 \%$ dos filhos dos proprietärios e apenas $58,4 \%$ dos filhos dos arrendatários deixaram as categorias de seus pais, enquanto que $74,3 \%$ dos filhos dos assalariados fixos e $68,0 \%$ dos filhos dos assalariados eventuais mudaram para categorias diferentes daquelas de seus pais. Consequentemente esses resultados con- 
cordam com os de PIHLBLAD e GREGORY (1957:49), os quais tambëm verificaram que, a mobilidade tende a ser maior nas cate gorias do fundo do que nas do topo da estrutura ocupacional. Esses resultados também demonstram que, hä mais mobilidade entre as categorias do topo, isto é, apenas entre as categorias dos parceiros, arrendatários e proprietários por um lado, e entre as categorias do fundo, isto é, apenas entre as categorias dos assalariados eventuais e assalariados fixos por outro lado, do que entre as categorias do fundo e as do topo da estrutura ocupacional. Muito provavelmen te o que torna essa mobilidade mais dificil säo principalmen te os fatores economicos e educacionais. De um modo geral as categorias de trabalhadores, mais do topo da estrutura ocupa cional, exigem um nível educacional mais elevado e principal mente mais recursos economicos, o que geralmente os assalariados fixos e eventuais estão longe de possuir. Nas categorias do fundo, tudo o que $\vec{e}$ exigido dos trabalhadores são principalmente suas habilidades manuais ou seus trabalhos braçais. Consequentemente os fatores econômicos e educacionais passam a agir como barreiras, que impedem esses agricul tores de subirem das categorias do fundo para as do topo da estrutura ocupacional.

A passagem das categorias do fundo para as do topo da estrutura ocupacional, estä relacionada às mudanças das ocupaçōes manuais para as năo-manuais. Segundo SMELSER e 
LIPSET (1966:20), as mudanças entre essas ocupações geralmen te estão relacionadas ao crescimento económico das regiōes onde elas ocorrem. Dada a natureza das ocupaçōes agrícolas, è difícil distinguir entre tais ocupaçōes, pois geralmente todas elas envolvem, em maior ou menor grau, as atividades manuais ou braçais. Assim, na população estudada, tudo o que pudemos verificar foi que a mobilidade do fundo para o topo da estrutura ocupacional é a menos frequente e estä relacionada às mudanças das categorias de trabalhadores, que são essencialmente manuais ou braçais, para as categorias onde eles não são essencialmente assim. Em consequência, dadas as declaraçöes de SMELSER e LIPSET de que essas mudanças estäo relacionadas ao crescimento econômico das regiões onde elas ocorrem, concluimos que provavelmente esse crescimento não tem sido muito significativo na região estudada.

Segundo os dados da Tabela $11,25,7 \%$ dos fiIhos dos assalariados fixos e $24,0 \%$ dos filhos dos assalaria dos eventuais conseguiram subir para a categoria dos proprie tärios. Através da Tabela 4 vimos que, de um modo geral esses agricultores têm um grau de escolaridade relativamente baixo. Em consequência isto parece negar a necessidade de um alto grau de escolaridade, para que muitos agricultores ascedam das categorias do fundo para as do topo da estrutura ocupacional. De fato, segundo LIPSET (1955), o mercado de trabalho, especialmente no setor agrícola, näo vem exigindo 
dos trabalhadores um grau elevado de escolaridade, mesmo para as ocupaçöes mais bem remuneradas. Portanto, se algum empregador seleciona seus empregados com base no grau de escolaridade, isto pode nada ter a ver com as tarefas que eles irāo executar. Mesmo que sejam específicas, dada a atual divisão do trabalho, essas tarefas geralmente poderão ser apren diáas em poucos dias, no prōprio emprego, não requerendo nenhum treinamento anterior. Se a escola treinasse os agricul tores para o trabalho, ela poderia se constituir num dos principais agentes de sua mobilidade. Entretanto, parece que a escolarização no campo nāo tem facilitado a mobilidade dos agricultores e, de fato, ali as principais chances de mobili dade social nāo necessariamente pertencem aos que têm mais titulos escolares, ou mais conhecimentos técnicos. Na zona rural, atualmente, um dos titulos mais valorizados é o de proprietärio de terras e, como sabemos, para a sua obtençāo nem os títulos escolares ou os conhecimentos técnicos têm si do muito necessärios.

Frequentemente tem sido observado que a escola rizaçāo no campo estimula a migraçāo dos agricultores, pois, geralmente são os mais escolarizados que deixam o campo para irem às cidades. Isto ocorre principalmente porque, na zona rural, há uma clara contradição entreas aspiraçōes que a escolarização desperta nas pessoas e os meios que o ambiente rural lhes possibilita para subirem socialmente. Segundo 
PATRICK (1975b:10), a política econômica atual parece pôr ênfase no uso cada vez maior de nova tecnologia na agricultú ra. Sabe-se que isto agrava o problema da renda dos agricultores, entretanto esta medida é considerada essencial para elevar a produtividade agricola. Os técnicos nesses assuntos têm chegado à conclusāo de que, os problemas da baixa renda dos agricultores näo podem ser resolvidos apenas em termos do mundo agricola e, por isto, a política económica atual tem posto ênfase na escolarizaçāo dos jovens agricultores, no sentido de ajudä-los a irem se empregar no setor urbano. Entretanto, como vimos, muitas ocupaçōes que representam meI hores condiçōes de vida para os agricultores nāo têm requerido deles muita escolaridade e pode haver agricultores que, apesar de terem alcançado um grau de escolaridade relativamente elevado, tiveram que permanecer na mesma categoria de trabalhador, ou teriam que emigrar para a cidade para conseguir emprego melhor. E assim que a escolaridade, na zona rurual, pode transformar-se num motivo de ressentimento e numa das razōes pelas quais muitos agricultores abandonam a estrutura ocupacional do campo, para concorrer no mercado de trabalho das cidades.

Atravës da Tabela 11 observamos também que, a mobilidade dos agricultores tem diminuido a tradição e tem introduzido muita heterogeneidade nas categorias dos trabaIhadores consideradas. Isto se deve ao fato de que, em cada 
categoria, exceto na dos proprietários, é bastante maior a proporção dos trabalhadores oriundos de outras categorias. Por exemplo: quanto aos parceiros, nenhum dos trabalhadores é oriundo dessa categoria, 55,6\% vieram da categoria dos pro prietärios e os demais são originários de todas as outras; entre os assalariados fixos, apenas $19,1 \%$ säo oriundos dessa categoria, 61,7\% vieram da categoria dos proprietários e os demais também são originários de todas as outras. Quanto aos arrendatários e assalariados eventuais verificam-se resultados semelhantes. Isto demonstra que, de fato, em todas as ca tegorias, exceto na dos proprietários, a grande maioria dos trabalhadores têm uma origem ocupacional bastante heterogênea e não são tradicionais ou antigos em suas categorias . Talvez seja esta uma das razöes pelas quais parece estar diminuindo a solidariedade entre os trabalhadores nas fazendas e talvez seja por isto também que dificilmente eles agem como uma unidade.

Na mobilidade entre as categorias dos agricultores, é interessante notar em que medida eles se adaptam às novas categorias nas quais ingressam, ou se eles retéom os velhos hábitos e costumes de suas antigas categorias. Pode haver conflito entre os antigos häbitos introjetados pelos trabalhadores e as exigencias de suas novas categorias. - que lhes acarreta muitos problemas e muita heterogeneidade nas categorias em que ingressam. Provavelmente é isto também 
o que está ocorrendo na região estudada. Por exemplo: tem s do observado que muitos assalariados eventuais, ao se instalarem nas fazendas, levam para alí os hábitos e costumes nômades ou seminômades de sua categoria, o que faz com que se alterem os hábitos de trabalho e mesmo a maneira de viver dos poucos antigos moradores ou colonos que ainda residem ali. Segundo GERMANI (1966), esta heterogeneidade nas categorias dos trabalhadores tambēm è provocada, quando os trabalhadores agrícolas se movem para a categoria dos operários das indústrias nas cidades. Eles levam para sua nova catego ria muitos dos seus antigos hábitos e costumes de trabalho, provocando muita heterogeneidade na categoria dos operários das indūstrias.

Em consequência da grande mobilidade hoje exil tente no setor agrícola, especialmente nas categorias dos as salariados fixos e eventuais, não mais têm se desenvolvido. nas fazendas, os grupos de trabalhadores com os costumes ou com a maneira de viver dos antigos colonos. Atualmente nas fazendas os trabalhadores frequentemente nem chegam a desenvolver as relaçōes primárias ou a solidariedade entre si. Nes se sentido são bastante significativas as declaraçōes de um dos agricultores entrevistados que assim se expressou: "Tem muita gente nova nessa fazenda. Agora, aqui, sö nós somos an tigos. Os outros são gente estranha que vieram de fora. Eu não gosto de ser vizinho deles, nem de ir trabalhar com eles. 
Hoje é muito diferente daquele tempo em que a gente ia trabalhar com os antigos colonos. A gente tinha confiança neles. Has eles foram embora e eu estoupensando em mudar daqui tambëm". Isto mostra que a mobilidade dos agricultores, principalmente aquela relativa às categorias mais baixas, alëm de ser bastante elevada, ocorre num espaço de tempo relativamen te curto, nāo dando oportunidade aos trabalhadores de desenvolveram uma tradição em seus grupos, nem de consolidarem suas relaçōes sobre bases mais duradouras.

Como podemos compreender, os custos da mobilidade são mais elevados para os agricultores quando as catego rias que eles atravessam são bastante amplas, ou quando elas possuem características bastante diferentes. No caso da mobi lidade descendente, então, aos custos normais dessa mobilida de, devemos acrescentar as grandes frustraçōes que o individuo experiencia pelo fato do seu nivel de vida elou de prestígio ter baixado bastante. Segundo GERMANI (1966:367), entretanto, os custos e as frustrações da mobilidade poderiam ser reduzidos, se fossem diminuidas as diferenças entre as categorias mais imediatas através das quais os individuos se movem e se as frustraçōes relativas à mobilidade descendente fossem compensadas, dando-se às pessoas que desceram novas oportunidades de participarem de outras vantagens e beneficios que a sociedade oferece. Por exemplo: no caso dos agricultores que desceram da categoria dos proprietários para a 
dos assalariados fixos ou eventuais, seus sindicados deveriam procurar compensar os custos e as frustraçōes de sua mobi lidade, proporcionando-l hes novos recursos através dos quais eles próprios poderiam se amparar e melhorar sua situaçāo.

A descontinuidade na mobilidade refere-se ao fato dos agricultores, atravës de suas mudanças no trabalho, atravessarem uma ou mais amplas categorias de trabalhadores. Esta mobilidade implica em muitas descontinuidades, além daquelas relativas ao trabalho. Por exemplo, ela pode levar as pessoas a mudarem de residencia, de regiào e até as suas relaçöes com as instituiçōes. Segundo WILENSKY (1966), a mobilidade descontinua não é rara e é mais frequente nas categorias mals baixas da estrutura ocupacional. Assim, podemos su por que essa mobilidade tende a ser mais comum no setor agrí cola uma vez que, as ocupaçōes desse setor em geral são clas sificadas nos escalöes mais baixos da estrutura ocupacional da sociedade como um todo.

Podemos analisar a mobilidade descontinua dos agricultores estudados através da Tabela 11 . Ali verificamos que os casos mais extremos dessa mobilidade, no sentido descendente, referem-se à passagem dos agricultores da categoria dos filhos de proprietários para as categorias dos assalariados fixos ou eventuais. Neste caso os agricultores atra vessaram duas ou trēs categorias e, como mostra a tabela, seu nümero è relativamente grande, pois, dos que iniciaram suas 
carreiras como filhos de proprietärios, $27,9 \%$ hoje são apenas assalariados fixos e $17,3 \%$ säo apenas assalariados eventuais. Os casos mais extremos dessa mobilidade, no sentido ascendente, são os que ocorreram no sentido inverso, isto é, referem-se às mudanças dos agricultores das categorias de filhos de assalariados fixos ou eventuais para a categoria dos proprietärios: $25,7 \%$ dos filhos dos assalariados fixos e $24,0 \%$ dos filhos dos assalariados eventuais tornaram-se proprietários. Portanto, sāo esses os principais casos de mobilidade descontinua ascendente e descendente ocorridos na população estudada. Muito provavelmente, para a maioria dos agricultores que a realizaram, tal mobilidade implicou em mu danças nas suas relaçōes com as instituiçōes, com os famili ares e amigos e em mudanças de residência ou de ärea residen cial.

0 ajustamento dos agricultores móveis às novas categorias, tambëm será mais difícil e custoso quanto maior forem as descontinuidades entre elas. A congruencia entre elas serä maior onde as diferenças entre as condiçōes de tra balho näo forem marcantes e serä maior ainda onde as ocupaçōes forem organizadas em carreiras. Segundo WILENSKY (1966: $112)$ essas condiçōes contribuem para tornar a mobilidade menos custosa e mais fäcil, especialmente se o indivíduo móvel desenvolve a mobilidade junto com sua familia. Nesse caso ele nāc apenas terá mais satisfação com a mobilidade, como 
tambēm poderá ser ajudado pela família a fazer as adaptaçōes às novas situaçōes em que tiver de ingressar, reduzindo assim as tensões que essas mudanças provocam.

Um dado tipo de estrutura ocupacional tende a desaparecer quando a mobilidade nela existente nāo é institucionalizada, ou quando hä grande desequilibrio entre as aspiraçōes dos trabalhadores e suas chances de mobilidade (GERMAN1, 1966:371). Esta ē uma situaçāo bastante comum na zona rural, especialmente entre os agricultores de baixa ren da, como é o caso aqui estudado. Como vimos, esses agriculto res alëm de terem um baixo nível de renda, têm, também, um baixo grau de escolaridade. Consequentemente para eles, tanto as chances como os canais de mobilidade tendem a ser pouco numerosos. Por isso há, na populaçāo estudada, tambēm muitos casos de mobilidade não institucionalizada ou pouco institucionalizada, o que provoca muita desorganização na sua estrú tura ocupacional. Segundo WILENSKY (1966:105), onde hä carreiras ordenadas e onde um emprego leva a outro, há mais integraçāo no trabalho e este è mais integrado à vida e à comu nidade. Entretanto, onde hä descontinuidade ocupacional e on de um emprego nāo leva a outro, o que geralmente observa-se é um acentuado desemprego, muita desordem nas mudanças de em prego, fraca dedicaçāo ao trabalho e pouca ligação entre o trabalho, a vida e a comunidade. Sem dūvida estas são algumas caracteristicas que tambëm podem ser observadas na popu- 
lação estudada. Elas refletem-se, inclusive, no número relativamente grande de vezes que os agricultores abandonaram suas categorias de trabalhadores para ingressarem em outras. E assim que, através dos quadros do Apêndice, podemos verifi car por exemplo que, dentre os filhos dos proprietärios (Apên dice 1), $14,4 \%$ mudaram 4 vezes de categoria; dentre os fiIhos dos arrendatärios (Apêndice 2), 50,0\% mudaram 3 vezes,e dentre os filhos dos assalariados fixos (Apêndice 3) e fiIhos dos assalariados eventuais (Apêndice 4), 22,9\% e 16,0\% respectivamente, mudaram também 3 vezes de categoria. Portan to, esses agricultores tendem a mudar muito frequentemente e muito abruptamente de emprego ou de categoria de trabalhador. Essas descontinuidades da estrutura ocupacional estudada refletem-se também no fato de que, um grande nü mero dos seus trabalhadores agrícolas não reside no campo mas, na periferia das cidades pröximas. Cerca de $22,3 \%$ deles săo assalariados eventuais e, como sabemos, a eventualidade dos seus empregos geralmente não os estimula a se dedicarem ao trabalho ou à suas ocupações; $37,1 \%$ deles exercem efetiva mente outra ocupação ao lado de suas ocupaçōes principais e $20,7 \%$ anda, também, à procura de trabalhos adicionais. Enfím todos esses fatores contribuem bastante para que haja certa desorganização, ou mesmo certa desordem, na estrutura ocupacional estudada.

Isto significa que a mobilidade não institucio 
nalizada e a complexidade e polivalência das ocupaçōes agricolas introduzem muita incongruencia na estrutura ocupacional. Dada a sua própria natureza, a mobilidade nāo institucionalizada é uma poderosa fonte de tensōes, frustraçōes e ressentimentos. Ela tem mais chances de ocorrer na medida em que aumenta a mobilidade porque, com esse aumento tende a a mentar o número dos trabalhadores incongruentes na estrutura ocupacional. Quando o nümero desses trabalhadores aumenta e aumentam os indices de mobilidade, a homogeneidade interna das categorias dos trabalhadores tende a diminuir. Consequen temente diminuem tambëm as brechas relativas às diferenças entre essas categorias, diminuindo assim as descontinuidades entre elas. Logo, esses fatores alteram a estrutura ocupacio nal e tendem a enfraquecer a solidariedade entre os membros das categorias de trabalhadores. Segundo WILENSKY (1966:124), é assim que a mobilidade irregular ou descontinua contribui para um maior movimento na estrutura ocupacional. Esses movi mentos, entretanto, tendem a ser abruptos e imprevisiveis. Eles podem levar à destruiçäo de muitos laços de parentesco e amizade, podem criar muitas situações instäveis e desordenadas nos empregos, levando às descontinuidades relativas às migraçōes e a tudo o que elas implicam.

Como vemos, são bastante amplos e variados os efeitos da mobilidade estudada. Entretanto, uma de suas prín cipais consequências é que ela leva os individuos a aceita- 
rem ou a rejeitarem a ordem social em que vivem. Ela è uma força integradora dos individuos, quando é igualmente possivel em todas as categorias de trabalhadores, quando a hierar quia e a descontinuidade entre essas categorias é minima e quando permite os ajustamentos às värias condições de traba1ho. Nesse caso os custos da mobilidade sāo pequenos e o balanço entre a aspiraçāo de mobilidade e a mobilidade efetiva que o individuo realiza, o leva a um maior envolvimento e a uma maior aceịtaçāo da ordem social (GERMANI, 1966:376). Em ültima anălise então, o que realmente importa é o balanço que o individuo faz entre a mobilidade que efetivamente tem realizado e suas aspiraçōes de mobilidade, principalmente aquelas estabelecidas em funçāo de seus grupos de referência, ou seja, daqueles em relação aos quais ele avalia a maior parte de suas privações e recompensas na sociedade.

A mobilidade ascendente parcialmente bloqueada geralmente constitui-se em fonte de ressentimentos e tensões e frequentemente leva as pessoas a alienarem-se da sociedade e de si mesmas. Entretanto, se o trabalhador satisfaz suas ambições, ou se a sua mobilidade não é bloqueada, isto o liga mais à sociedade, nāo o aliena. Por essas razões, segundo WILENSKY (1966:123), as pessoas mais alienadas geralmente sāo encontradas nas categorias mais baixas dos trabalhadores e vice-versa. Segundo esse autor, é bem conhecida a teoria do papel estratégico de um grupo parcialmente 
frustrado nos primeiros estägios de seu desenvolvimento ócupacional. Essa teoria admite que, se as aspirações de mobili dade da população são completamente satisfeitas, não surgirä na sociedade nenhuma atitude revolucionäria, nenhum comporta mento inovador. Por outro lado, a mobilidade descendente par cialmente bloqueada também pode agravar as tensōes sociais, especialmente se restarem às pessoas que caem algum poder ou recursos através dos quais elas possam se rebelar.

Também na população estudada é bastante signi ficativa a mobilidade parcialmente bloqueada, através das ca tegorias dos trabalhadores. Pela Tabela 11 verificamos que, em todas as categorias consideradas é relativamente grande a proporção das pessoas móveis em ambos os sentidos, isto $\vec{e}$, no sentido ascendente e descendente. Dentre os que iniciaram suas carreiras como filhos de assalariados eventuais, $\quad 24,0 \%$ conseguiram tornar-se apenas assalariados fixos, $20,0 \%$ torna ram-se parceiros ou arrendatários e $24,0 \%$ conseguiram tornar-se proprietários. Para a maioria dessas pessoas, então, a aspiração de tornarem-se proprietários, arrendatārios ou parceiros foi impedida por sua mobilidade ascendente parcial mente bloqueada, gerando todo tipo de tensão e de ressentimentos em que isto implica. No sentido descendente, vemos que $21,1 \%$ dos que iniciaram suas carreiras como filhos de proprietārios, hoje são apenas arrendatärios ou parceiros e $27,9 \%$ desceram até a categoria dos assalariados fixos. Para 
essas pessoas então, a mobilidade descendente tambëm foi par cialmente bloqueada, uma vez que não desceram atë o fundo da estrutura ocupacional. Quanto às demais categorias e em rela ção à mobilidade ascendente, observa-se o mesmo processo:hä värias proporções significativas de agricultores que também conseguiram realizar apenas uma mobilidade parcialmente bloqueada, ou seja, foram bloqueados na realizaçäo das suas aspirações de mobilidade. Se a todos esses casos de mobilidade ascendente parcialmente bloqueada, juntarmos todos os casos de mobilidade descendentes antes analisados, entäo poderemos inferir que, sem düvida, hä muita tensão, ressentimentos e alienação na estrutura ocupacional da população estudada.

A Tabela 12 expõe a mobilidade dos agriculto res estudados, mostrando as frequências e percentagens dos que estão na mesma categoria ou em categorias de trabalhado res diferentes daquelas de seus pais.

Esta tabela mostra que, $32,0 \%$ dos agricultores estudados permaneceram nas mesmas categorias de trabalhadores de seus pais. Portanto a maioria, ou seja $68,0 \%$, mudou para outras categorias. Dentre as categorias consideradas, observa-se que são principalmente a dos proprietärios $(33,7 \%)$ e a dos arrendatários, $(41,7 \%)$ as que têm mais força em subordinar o trabalho dos filhos e, portanto, émais nessas duas categorias que se observa certa herança ocupacional entre as gerações estudadas. As categorias que demonstram me- 
TABELA 12. Frequência e Percentagem dos Agricultores Entrevistados, que estão na mesma Categoria ou em Cate gorias de Trabalhadores diferentes daquelas de seus Pais, Vale do Ribeira, 1973.

\begin{tabular}{|c|c|c|c|c|c|}
\hline \multirow{2}{*}{\multicolumn{2}{|c|}{$\begin{array}{l}\text { categorias dos pais } \\
\text { dos agricultores }\end{array}$}} & \multirow{2}{*}{$\begin{array}{c}\text { na mesma } \\
n\end{array}$} & \multirow{2}{*}{$\begin{array}{c}\text { categoria } \\
\%\end{array}$} & \multicolumn{2}{|c|}{$\begin{array}{l}\text { em categorias } \\
\text { diferentes }\end{array}$} \\
\hline & & & & $n$ & $\%$ \\
\hline proprietärios & $N=104$ & 35 & 33.7 & 69 & 66,3 \\
\hline arrendatärios & $N=12$ & 5 & 41,7 & 7 & 58,3 \\
\hline parceiros & $N=$ & 0 & 0 & 2 & 100,0 \\
\hline $\begin{array}{l}\text { assalariados } \\
\text { fixos }\end{array}$ & $N=35$ & 9 & 25,7 & 26 & 74,3 \\
\hline $\begin{array}{l}\text { assalariados } \\
\text { eventuais }\end{array}$ & $N=25$ & 8 & 32,0 & 17 & 68,0 \\
\hline TOTAL & $=178$ & 57 & 32,0 & 121 & 68,0 \\
\hline
\end{tabular}

nos influência, nesse sentido, são a dos parceiros e a dos assalariados fixos. Em consequência, sāo principalmente as categorias dos proprietários e dos arrendatários as que mais têm contribuído para a imobilidade dos agricultores, enquanto que säo principalmente as categorias dos parceiros e dos assalariados fixos as que mais têm contribuido para sua mobili 
dade. Segundo PATRICK (1975a), nos países subdesenvolvidos ou nas regiōes em desenvolvimento, como é o caso aqui estuda do, o prestígio das familias dos proprietärios vem principal mente da propriedade da terra, ainda que ela não lhes propor cione grande rentabilidade. Em consequência, para conservarem seu prestigio essas familias insistem em conservar a pro priedade da terra, mesmo às custas de consideráveis prejuízos econômicos. Esta é uma das razōes pelas quais, principal mente nas regiōes em desenvolvimento, os proprietários de terra frequentemente nasceram nessa mesma categoria e, inclú sive, na mesma região onde vivem. De fato, tanto no Vale estudado como em outras regiōes agrícolas pobres, parece que são principalmente os pequenos e os grandes proprietários de terra os que mais se esforçam em permanecer nessa categoria que, era a mesma de seus pais. Apesar disto convém notar que, conforme mostra a Tabela 12, em todas as categorias sem pre è bastante menor a proporção dos agricultores que se man tiveram na mesma categoria de seus pais, ou, é sempre maior a proporção daqueles que mudaram. Portanto isto demonstra que, todas as categorias de agricultores consideradas de um modo geral têm contribuido mais para a mudança do que para a estabilidade da estrutura ocupacional estudada.

A mobilidade dos agricultores, atravēs das categorias dos trabalhadores agricolas, altera a estrutura ocu pacional da comunidade onde ocorre. 0 impacto dessa mobilida 
de depende, principalmente, dos volumes das categorias de onde os agricultores saem e dos volumes daquelas onde eles entram: quanto menor for esses volumes, mais significativas serão as entradas e as saidas dos agricultores. Pela Tabela 12. podemos verificar esse movimento na populaçāo estudada. Vemos que as categorias menos volumosas são as dos arrendatá rios e parceiros, pois, representam apenas $7,9 \%$ da população. A maioria desses agricultores, isto è, $58,3 \%$ dos arrendatários e 100,0\% dos parceiros, hoje estão em categorias di ferentes daquelas de seus pais. Portanto, além dos volumes dessas categorias serem os menores, a grande maioria dos seus agricultores são originärios de outras categorias. Sem düvida isto tem influências bastante significativas sobre os agricultores e sobre a estrutura ocupacional estudada. Por exemplo, é muito provàvel que, nas categorias menos volumosas e constituidas mais por pessoas oriundas de categorias diferentes, a coesão e a solidariedade entre os agricultores seja menor.

As chances das pessoas subirem na estrutura - cupacional dependem das oportunidades que objetivamente. existem para isto, dependem das pessoas perceberem ou não essas oportunidades e dependem de certas qualidades ou carac teristicas das pessoas. Segundo CROCKETT (1966:291), geralmente são as pessoas que têm mais habilidades empäticas e mais criatividade as que têm mais chances nesse sentido.Mais 
especificamente os estudos sobre a mobilidade no setor rural têm demonstrado que, a mobilidade ascendente ou descendente dos agricultores está relacionada aos seus lugares de origem. Os imigrantes, em uma dada localidade, tendem a realizar a mobilidade ascendente mais frequentemente do que os na tivos locais. Estes, mais frequentemente que os imigrantes, tendem apenas a conservar suas posiçōes ou podem descer para categorias mais baixas na estrutura ocupacional. Muito prova velmente as diferenças de mobilidade, entre os imigrantes e os nativos, estão relacionadas às suas categorias de trabalhadores, à personalidade bàsica dos que emigram e principal mente aos diferentes tipos de coerção que a comunidade local exerce sobre os nativos e nāo sobre os imigrantes. Foi no sentido de verificarmos as relaçōes, entre a mobilidade dos agricultores e os seus lugares de origem, que organizamos os dados conforme mostra a Tabela 13.

Esta tabela mostra a relação entre a mobilidade dos agricultores estudados e seus lugares de origem ou de nascimento. Vemos que $32,0 \%$ dos agricultores não têm sido mó veis na estrutura ocupacional e a maior proporção deles, isto $\vec{e}$, cerca de $43,9 \%$ ainda hoje residem no mesmo município onde nasceram e, portanto, são nativos locais.Cerca de $34,7 \%$ desses nativos têm se conservado imóveis na estrutura ocupacional, $52,8 \%$ têm realizado uma mobilidade descendente e $12,5 \%$ ascendente. Dos agricultores que hoje residem no Vale 
TABELA 13. Mobilidade Social dos Agricultores Entrevistados e seus Lugares de Origem, Vale do Ribeira, 1973.

\begin{tabular}{|c|c|c|c|c|c|}
\hline \multirow[b]{2}{*}{ Mobilidade } & \multicolumn{2}{|c|}{ LUGARES } & NASCII & ENTO & \multirow[b]{2}{*}{$\begin{array}{l}\text { Outros } \\
\text { Países }\end{array}$} \\
\hline & $\begin{array}{c}\text { Munici- } \\
\text { pio on- } \\
\text { de resi } \\
\text { de } \\
\%\end{array}$ & $\begin{array}{l}\text { Vale do } \\
\text { Ribeira }\end{array}$ & $\begin{array}{l}\text { Outras } \\
\text { regioes } \\
\text { do Esta } \\
\text { do de } \bar{s} \text {. } \\
\text { Paulo } \\
\%\end{array}$ & $\begin{array}{l}\text { Outros } \\
\text { Estados }\end{array}$ & \\
\hline ascendente & 12,5 & 19,5 & 35,7 & 25,0 & 0 \\
\hline i mövel & 34,7 & 31.7 & 42,9 & 20,8 & 100,0 \\
\hline descendente & 52,8 & 48,8 & 21,4 & 54,2 & 0 \\
\hline TOTAL & $\begin{array}{r}100,0 \\
(72)\end{array}$ & $\begin{array}{c}100,0 \\
(41)\end{array}$ & $\begin{array}{r}100,0 \\
(14)\end{array}$ & $\begin{array}{r}100,0 \\
(48)\end{array}$ & $\begin{array}{c}100,0 \\
(3)\end{array}$ \\
\hline
\end{tabular}

do Ribeira, mas que nasceram em outras regiōes do Estado de São Paulo, 42,9\% têm se mantido imóveis na estrutura ocupacional, apenas $21,4 \%$ realizaram uma mobilidade descendente, enquanto que $35,7 \%$ realizaram uma mobilidade ascendente. Portanto, verifica-se que os agricultores nativos locais têm tido menos chances que os imigrantes que ali chegaram de permanecer em suas categorias de trabalhadores, ou de ascender na estrutura de prestígio que elas representam. Mais frequentemente que os imigrantes, os nativos locais tendem a 
descer nessa estrutura. Assim, esses resultados concordam com as observações de HOSELITZ (1966:191) de que, as pessoas nativas nas diferentes localidades geralmente tendem a ser mais tradicionais e pretendem menos que os imigrantes, ou se esforçam menos que eles, para melhorarem em suas posições so ciais ou ocupacionais.

Pela Tabela 13 verificamos também que, dentre os agricultores que têm realizado uma mobilidade descendente, mais da metade, isto é, $66,7 \%$ são nativos dos municípios e do Vale estudados. Cerca de $36,0 \%$ dos imigrantes vindos de outras regiōes do Estado de São Paulo e $25,0 \%$ dos que vieram de outros Estados realizaram uma mobilidade ascendente. Entretanto, dos agricultores nativos dos municípios e do Vale estudados, apenas $12,5 \% \odot 19,5 \%$, respectivamente, têm reali zado essa mobilidade. Portanto, esses resultados também demonstram a relaçāo entre a mobilidade dos agricultores e seus lugares de origem, pois, tambēm segundo eles geralmente os imigrantes têm tido mais chances que os nativos de subirem atravès das categorias de agricultores.

\section{Mudanças na Estrutura Ocupacional}

$$
\text { Na zona rural, como vemos, frequentemente os }
$$

filhos dos agricultores mudam para ocupações ou para categorias de trabalhadores diferentes daquelas de seus pais. Frequentemente, inclusive, eles mudam para ocupações urbạnas e 
deixam a zona rural. E assim que no setor rural, mais comumente que no urbano, a mobilidade tende a ser de movimento näo-recíproco, ou seja, é menos comum o caso de uma pessoa ocupar a posição deixada por uma outra. Por essa razão a mobilidade nesse setor, especialmente a dos agricultores mais jovens, tende a provocar mudanças na estrutura ocupacional, pois, em vez deles acentuarem as tendências existentes nas ocupaçōes, mais frequentemente eles as interrompem deixando a agricultura e evadindo-se para as cidades. De fato, segundo RAMSOY (1966:222), quanto mais rural e menos industrializado for o ambiente, menor serä a semelhança entre a estrutura ocupacional dos pais e a dos filhos, pois, mais frequentemen te os filhos tenderäo a abandonar a estrutura relativa à geração dos pais. Portanto, é assim que no setor rural geralmente os agricultores acabam contribuindo para que a estrutü ra ocupacional se modifique, tanto no volume como no nümero de suas categorias.

Na região estudada estão sendo aceleradas as mudanças nos setores econômico e social, e isto também tem provocado muitas mudanças em sua estrutura ocupacional. Segundo PATRICK (1975a:23), em parte essas mudanças se devem ao Estatuto da Terra e Estatuto do Trabalhador Rural, os quais começaram a ser ali aplicados a partir de 1963/64. Devido às aplicações desses estatutos muitos assalariados fixos dispensados de seus empregos, outros permaneceram no em- 
prego mas passaram a trabalhar sob novas condiçōes, outros, ainda, foram expulsos das fazendas ou transformados em assalariados eventuais. A dispensa dos assalariados fixos, em parte veio contribuir para que outros agricultores encontras sem trabalho nas fazendas, acentuando assim as transformações que as aplicaçōes dos estatutos em questäo tèm introduzido na estrutura ocupacional.

A Tabela 14 mostra a distribuição dos agricultores estudados e a de seus pais, segundo suas categorias de trabalhadores, evidenciando as estruturas ocupacionais relativas a essas duas gerações e as mudanças entre elas ocorridas.

Segundo esta tabela, houve mudanças bastante significativas na estrutura ocupacional da população estudada. De fato a ordem dos volumes das suas categorias não se modificou, pois, por exemplo, as categorias dos proprietários e parceiros são, respectivamente, as mais e as menos vo lumosas, tanto na estrutura relativa à geração dos agricultores. Entretanto, os volumes das categorias se alteraram bastante. Tuanto à categoria mais valorizada, ou seja, a dos proprietärios, o volume foi reduzido pela metade, isto $\vec{e}$, de $56,5 \%$ para $28,3 \%$ e os das demais aumentaram bastante, exce to os das categorias dos autōnomos não-agricolas e assalaria dos urbanos as quais deixaram de existir. Consequentemente esses resultados confirmam as observaçōes de DUNCAN (1966: 
.84.

TABELA 14. Frequència e Percentagem dos Agricultores e de seus Pais, segundo as Categorias de Trabalhadores, Vale do Ribeira, 1973.

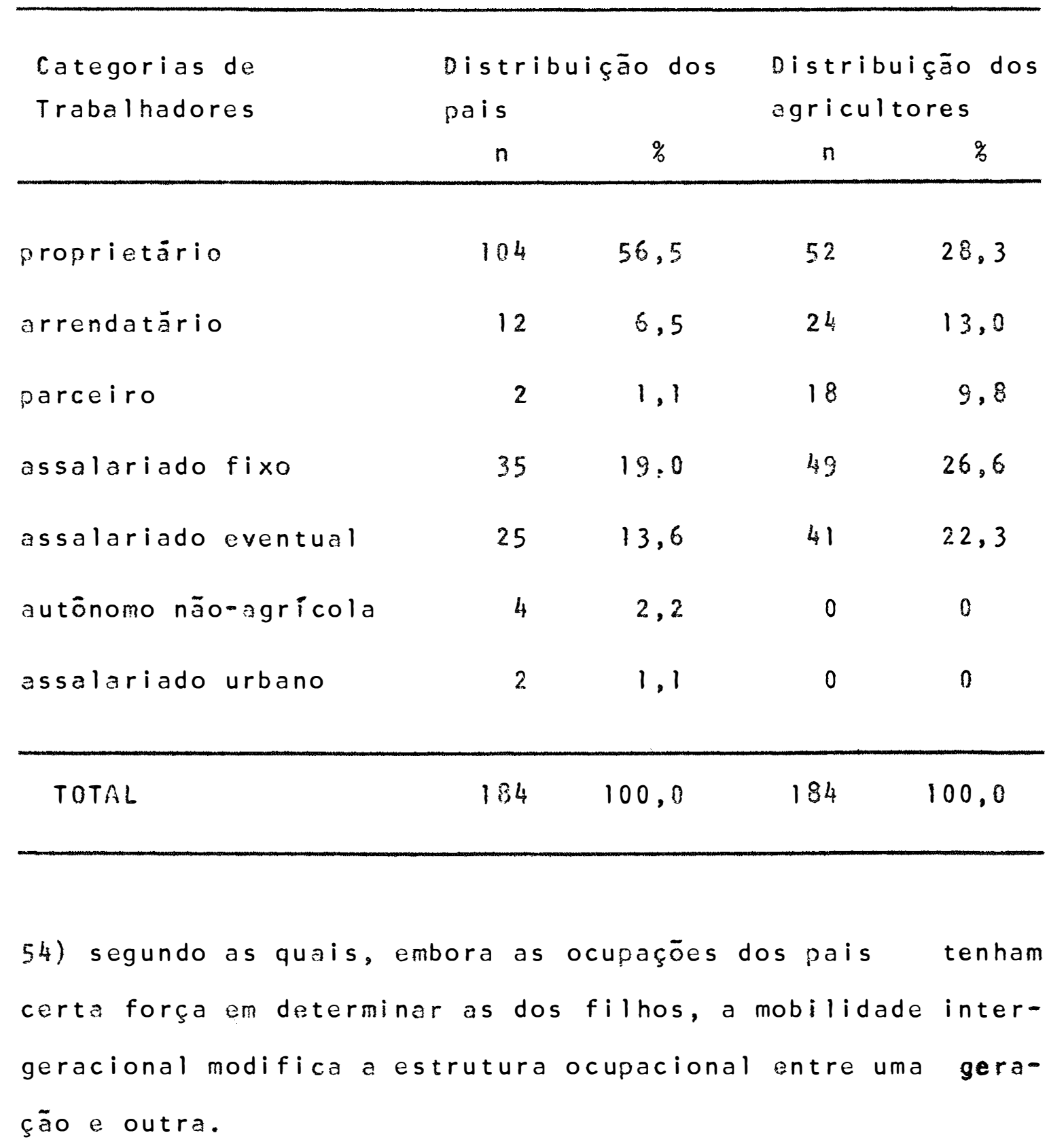

Segundo os dados obtidos, quase a metade dos 
agricultores estudados, ou seja, cerca de $49,0 \%$ deles têm realizado uma mobilidade descendente, huito provavelmente ís to ocorre porque, conforme observa RAMSOY (1966), no setor rural o aumento da população não tem sido proporcional, ou tem sido maior que o aumento no nümero das posições na estrü tura ocupacional. Isto se dá principalmente nas categorias mais elevadas de trabalhadores, daí a razão da maioria dos agricultores estudados ter descido para os escalōes mais baixos da estrutura ocupacional. E assim que a mobilidade no campo ocorre principalmente em função das modificaçōes nessa estrutura, seja pela criação de novas categorias de trabalhadores, ou pela mudança nos volumes das categorias existentes. Na medida em que aumentam as posiçöes no topo da estrutura, as pessoas tendem a subir atravës das categorias de agricultores; na medide em que essas posiçōes se restringem, as pessoas tendem a descer. Na população estudada a mobilidade estrutural também tem sido muito significativa, pois, como vimos, as proporçōes entre as categorias dos agricultores modificaram-se bastante entre as geraçōes estudadas, ten do se restringido o volume da categoria dos proprietários e a umentado os das demais. Assim vemos que, de fato, no setor rural a mobilidade age mais no sentido de modificar a estrutura ocupacional, pois não apenas muitos agricultores abandonam o campo indo para as cidades, mas muitos tambëm descem para os escalöes mais baixos dessa estrutura. 
Na estrutura estudada $68,6 \%$ dos proprietários e $50,0 \%$ dos arrendatärios são filhos de proprietärios. Portanto, as duas categorias mais prestigiadas continuam sendo dominadas pelos filhos dos agricultores que, no passado tambēm tinham mais prestígio na população. Assim, hä relativamente poucos homens novos nas categorias do topo da estrutura ocupacional, pois o prestígio parece ter continuado nas mãos das mesmas famílias durante as duas geraçōes estudadas. De fato, segundo SELIGMAN $(1966: 361)$, no presente parecem es tar desaparecendo os canais de recrutamento de novas pessoas para as categorias do topo da estrutura ocupacional,especial mente para a categoria dos proprietários e isto ocorre principalmente porque o desenvolvimento sócio-econōmico pode atrofiar ou aumentar a demanda nas diferentes categorias.

A anālise da mobilidade aqui realizada corresponde à anālise da força com que a estrutura ocupacional que existiu no passado, atravēs da geração dos pais, determinou a estrutura do presente relativa aos agricultores estudados. Es sa determinação se deu em função da força com que as categorias de trabalhadores dos pais determinaram as dos filhos. Seră nas mesmas proporçōes aqui encontradas, que as atuais categorlas dos agricultores i rão determinar as categorias de agricultores dos seus filhos, no futuro? Será nessas mesmas proporçōes que a atual estrutura ocupacional irá determinar a futura estrutura ocupacional da população? Como podemos 
compreender, se as categorias de trabalhadores dos pais inva riavelmente determinarem as dos filhos, entāo essa estrutura deverá continuar, isto ë, deverá continuar tendo as mesmas proporçōes entre elas. Do contrário essa estrutura deverá se modificar, como vimos que se modificou, do passado para o presente, através das gerações estudadas.

Segundo PATRICK (1975b), há um movimento relativamente numeroso de migraçāo para a regiāo estudada. De fá to verificamos que, $36,5 \%$ dos agricultores estudados näo nas ceram no Vale do Ribeira e, portanto, sāo imigrantes ali. Se g undo PATRICK tambèm, hà um volume relativamente grande de migração para fora do Vale, e nesse sentido procuramos verificar quais eram os desejos dos agricultores estudados quanto às emigraçōes, ou quanto a mudarem dos lugares onde residem. São esses dados que expomos na Tabela 15 em funçāo das categorias dos agricultores.

Esta tabela mostra a distribuição dos agricul tores estudados, segundo as categorias de trabalhadores agri colas e suas indicaçōes dos lugares para mudança de residência. Vemos que mais da metade dos agricultores, ou seja. $57,7 \%$ nāo pretende fazer essa mudança, 69,6\% nāo pretende mu dar dos municipios onde residem e $72,7 \%$ näo pretende deixar - Vale do Ribeira. Dentre os grupos que pretendem mudar, os mais numerosos são os dos parceiros e assalariados eventuais, nos quais $57,2 \%$ e 49,0\% das pessoas, respectivamente,desejam 
.88 .

TABELA 15. Distribuiçāo Percentual dos Agricultores, segundo as Categorias de Trabalhadores Agrícolas e suas Indicaçōes dos Locais para Mudança de Residência, Vale do Ribeira, 1973.

\begin{tabular}{|c|c|c|c|c|c|c|}
\hline \multirow{2}{*}{$\begin{array}{c}\text { lugares ind } \underline{1} \\
\text { cados para } \\
\text { mudança }\end{array}$} & \multicolumn{5}{|c|}{$C A E G$ OAA S DS T RAB A LAD ORES } & \multirow[t]{2}{*}{ Total } \\
\hline & $\begin{array}{c}\text { proprie } \\
\text { tărio } \\
\%\end{array}$ & $\begin{array}{c}\text { arrenda } \\
\text { tärio } \\
\qquad\end{array}$ & $\begin{array}{l}\text { parcel } \\
\text { ro } \\
\qquad \%\end{array}$ & $\begin{array}{c}\text { assala } \\
\text { riado } \\
\text { fixo } \\
\%\end{array}$ & $\begin{array}{l}\text { assala } \\
\text { riado- } \\
\text { even- } \\
\text { tual } \\
\%\end{array}$ & \\
\hline $\begin{array}{l}\text { no mesmo mu } \\
\text { nicipio on } \\
\text { de reside }\end{array}$ & 13,6 & 5,9 & 19,1 & 11,4 & 11,8 & $\begin{array}{l}11,9 \\
(27)^{2}\end{array}$ \\
\hline $\begin{array}{l}\text { outros muni } \\
\text { cipios do } \\
\text { Vale do Ri- } \\
\text { beira }\end{array}$ & 1,8 & 0 & 14,3 & 3,2 & 2.0 & 3,1 \\
\hline $\begin{array}{l}\text { outras re- } \\
\text { giós do Es } \\
\text { tado de são } \\
\text { Paulo }\end{array}$ & 6,9 & 14,8 & 9,5 & 6,4 & 3,8 & $\left(\begin{array}{l}7,5 \\
(17)\end{array}\right.$ \\
\hline $\begin{array}{l}\text { outros Esta } \\
\text { dos }\end{array}$ & 3,4 & 0 & 0 & 3,2 & 11,8 & $\begin{array}{r}4,4 \\
(10)\end{array}$ \\
\hline não sabe & 11,8 & 17,6 & 14,3 & 14,5 & 19,6 & $\begin{array}{l}15,4 \\
(35)\end{array}$ \\
\hline $\begin{array}{l}\text { não pretente } \\
\text { mudar }\end{array}$ & 62,5 & 61,7 & 42,8 & 61,3 & 51,0 & $\begin{array}{l}57,7 \\
(13 i)\end{array}$ \\
\hline TOTAL & $\begin{array}{r}100,0 \\
(59)\end{array}$ & $\begin{array}{r}100,0 \\
(34)\end{array}$ & $\begin{array}{c}100,0 \\
(21)\end{array}$ & $\begin{array}{r}100,0 \\
(62)\end{array}$ & $\begin{array}{r}100,0 \\
(51)\end{array}$ & $\begin{array}{l}100,0 \\
(227)\end{array}$ \\
\hline
\end{tabular}


mudar. A maior proporção desses parceiros $(33,4 \%)$ pretende mudar apenas dentro do Vale do Ribeira, enquanto que a maior proporção desses assalariados $(35,2 \%)$ pretendem mudar mudar para fora desse vale ou não sabem para onde ir.

Esses resultados sugerem que, muito provavelmente o mercado de trabalho tem conseguido absorver apenas uma parte da māo-de-obra da regiāo. Como vimos, mais da meta de dos agricultores $(57,7 \%)$ não pretendem mudar dos lugares onde moram. Isto pode significar que, em parte o mercado de trabalho está absorvendo a māo-de-obra alí existente. Entretanto, $42,3 \%$ dos agricultores desejam mudar e a maior parte deles $(27,3 \%)$ pretende deixar o Vale do Ribeira, ou nāo sabe para onde ir. Provavelmente para esses agricultores o mercado de trabalho da regiāo tem sido deficiente, pois, geralmen te são os agricultores mais jovens que abandonam o campo e geralmente o fazem à procura de emprego. Entretanto segundo GALESKI (1972:42), devemos admitir que quando os agricultores jovens abandonam o campo, eles nāo o fazem apenas devido às condiçōes de trabalho. Eles o fazem, tambẻm, como uma atitude de revolta contra o padräo de vida rural, no qual eles sentem que nāo podem satisfazer suas aspiraçöes mais ca ras como as de obter independência econōmica e uma ocupaçāo técnica. Muitos desses agricultores acreditam que, mais facilmente poderāo satisfazer suas aspiraçōes deixando a agricultura, indo trabalhar nas indústrias e mudando-se para as 
cidades.

Segundo SJOBERG (1966:254), na medida em que a urbanizaçāo e a industrializaçāo alcançam as cidades e a zona rural, os grupos söcio-econômicos mais do topo da estrutü ra rural logo apoiam as novas tëcnicas agricolas que estão sendo difundidas e, entāo, em relaçāo ao desenvolvimento alcançado por essas camadas, as camadas mais do fundo dessa e trutura väo ficando para träs. Entretanto mesmo essas camadas mais baixas podem melhorar um pouco seu padrāo de vida, uma vez que a modernizaçāo tende a diminuir a mortalidade. a aumentar as chances de escolaridade e a fazer com que as familias tenham um pouco mais de conforto em seus lares. E isto tambēm o que se verifica na regiāo estudada alèm do fato de que, alí, a urbanizaçāo e a industrializaçāo tambēm têm levado muitos agricultores dessas camadas mais baixas a abandonarem a ārea em que vivem, principalmente em busca de melhores condiçōes de emprego e de habitaçāo.

Portanto observa-se que, a baixa renda associa da ao desenvolvimento sōcio-econōmico da regiāo, sāo dois fá tores que têm levado muitos agricultores a abandonarem o cam po para viver nas cidades. Segundo SJOBERG (1966:244), nas regiōes desenvolvidas esta evasāo do campo pode ser consequência do aumento da eficiência do trabalho e da produção agrícola, ao mesmo tempo que os emigrantes podem estar sendo atraídos pelo maior prestígio da vida urbana. Na regiāo 
estudada observa-se, inclusive, que näo são apenas os agri cultores pobres que abandonam o campo mas, também aqueles que possuem certos recursos e um melhor nivel de escolaridade. Como sabemos, o trabalhador agrícola pobre e analfabeto frequentemente nāo possui nem mesmo os recursos para abandonar sua ărea de pobreza. Entretanto se ele consegue ir para a cidade, pelo menos alí ele sente que pode sobreviver. Atra vés das entrevistas verificamos que os agricultores que emigram, geralmente, no início, vāo sem suas esposas. Quase sem pre eles vão à procura de melhores condições de trabalho, "arranjados" por seus parentes ou amigos que jä moram na cidade. Esse era, inclusive, o caso de alguns agricultores que estavam planejando mudar para São Paulo.

Devido à proximidade com os grandes centros co mo Sāo Paulo e Santos, e devido às vias de comunicaçāo que dão acesso ao Vale do Ribeira, muitas präticas agrícolas modernas estāo sendo introduzidas na região estudada. De fato, através das entrevistas pudemos verificar que, vărios produtores da região já usam muitas dessas präticas. Na regiāo pesquisada, na medida em que o trabalho agrícola se torna mais moderno, mais técnico e mais especializado, surgem novos canais de mobilidade, e é assim que a tecnologia agricola moderna tem contribuído bastante para aumentar a mobilidade na estrutura ocupacional estudada. Isto se dá, principalmente, nāo apenas porque essa tecnologia cria novas 
oportunidades de trabalho, mas porque também trasnfere muito trabalho braçal para as máquinas, criando novas necessidades de adaptação ao trabalho para os agricultores. Parece ser principalmente para satisfazer essas necessidades criadas pe la tecnologia agrícola moderna, que eles mais tēm desenvolvido sua mobilidade no presente.

$$
\text { Como vemos, tem sido relativamente grande a mo }
$$
bilidade dos agricultores atravēs da estrutura ocupacional estudada. A Tabela 16 resume essa mobilidade, mostrando as proporçōes dos que subiram, desceram e dos que se mantiveram imóveis nessa estrutura.

TABELA 16. Frequência e Percentagem da Mobilidade Social dos Agricultores, Vale do Ribeira, 1973.

\begin{tabular}{lcc}
\hline mobilidade & frequência & $\%$ \\
\hline ascendente & 34 & 19,1 \\
imóvel & 57 & 32,0 \\
descendente & 87 & 48,9 \\
\hline TOTAL & 178 & 100,0 \\
\hline
\end{tabular}


Esta tabela mostra que apenas $19,1 \%$ dos agricultores estudados conseguiram realizar uma mobilidade ascen dente, apenas $32,0 \%$ têm se mantido imóveis na mesma categoria de trabalhadores de seus pais, enquanto que quase a meta de, isto é, $48,9 \%$ realizaram uma mobilidade descendente, ou seja, desceram para categorias inferiores às de seus pais. Portanto esses resultados demonstram que, a mobilidade social representa frustração para a maioria dos agricultores e isto significa então que, hä um nümero relativamente grande de pessoas insatisfeiras com a estrutura ocupacional da pop $\underline{u}$ lação estudada.

Entretanto observamos que $19,1 \%$ dos agricultores realizaram uma mobilidade ascendente e, como geralmente acontece, o alarde que se faz do sucesso dessa minoria acaba fazendo com que seja esquecido ou näo notado o fracasso da maioria, ou seja, daqueles $48,9 \%$ que desceram na estrü tura ocupacional. As tensōes resultantes dessa mobilidade descendente podem também estar sendo reduzidas pela grande massa da população, que tem ganho certo conforto nos lares; podem estar sendo reduzidas pelo levantamento no padräo das ocupaçōes, que tem alcançado até as categorias mais baixas dos trabalhadores, e, finalmente, elas podem ainda estar sen do toleradas porque muitos do que descem culpam a si mesmos pelo fracasso, admitindo que o sucesso, no mundo do trabaTho, requer mais capacidade ou esforço do que eles possuem 
ou estariam dispostos a dispender (GERMANI, 1966).

4. Sucesso e Fracasso na Mobilidade dos Agricultores

Dados os valores envolvidos na estrutura ocupacional, todo o esforço de mobilidade desenvolvido pelas pessoas geralmente visa a obtenção de mais poder, mais prestígio, ou o sucesso. Assim, o sucesso é como que o objetivo ou a finalidade da mobilidade. Segundo WILENSKY (1966:118), - ideal de sucesso no passado traduzia-se no sucesso económico, mais especificamente, na aquisição de riqueza, de autonomia no trabalho, ou de independència econômica. Por isto, parece que no passado as pessoas se esforçavam mais nesse sentido. Atualmente, porém, parece que a maioria dos trabalhadores não têm uma clara ou firme conviç̧ão do que seja - sucesso. Para eles o ideal de sucesso jä não mais estä a sociado aos desejos de autonomia no trabalho, ou de independência econômica e sim, às aspiraçōes de terem segurança eco nômica, conforto em seus lares e de participarem de certas formas de lazer relativamente caras e refinadas. Essas aspi rações sāo mais caracteristicas dos trabalhadores urbanos, porëm fazem parte do ideal de sucesso de quase todas as pessoas em nossa sociedade, inclusive dos que trabalham no campo.

Portanto, tambëm na zona rural muitas aspirações dos agricultores estão relacionadas ao moderno ideal de 
sucesso. De fato, parece que atualmente a maioria dos agricultores já não mais se esforçam, como os do passado, por acumularem riqueza, por serem proprietários de terra, ou por terem autonomia no trabalho. A maioria parece desejar apenas um trabalho que lhes dê segurança econômica, ainda que numa situação de subordinados. Ao lado dessas aspirações hä, como disse WILENSKY (1966:118), um forte desejo de obterem mais conforto em seus lares e de participarem de certas formas de lazer relativamente caras.

Estreitamente associados a essas aspirações dos agricultores, estão seus desejos de aumentarem seus rendimentos ou recursos econômicos, seja isto como um objetivo em si mesmo, ou como um meio de concretizarem suas aspira çōes de sucesso. Por isto procuramos verificar quais eram suas aspirações quanto ao cultivo de uma área maior e quanto a terem ou não outra ocupação ao lado de suas ocupações prin cipais. São esses dados que apresentamos em seguida, nas Tabelas 17 e 18 .

A Tabela 17 mostra a distribuição dos proprietários, arrendatários e parceiros, quanto às suas aspirações relativas ao cultivo de uma ärea maior. Vemos que a maioria dos proprietários $(67,8 \%)$ e dos arrendatários $(87,4 \%)$ preten dem esse cultivo, entretanto, a maioria dos parceiros $(55,6 \%)$ não pretende. Provavelmente essa atitude dos parceiros se deve ao fato de que, frequentemente eles têm sido desestimula 
TABELA 17. Distribuição Percentual dos Proprietärios, Arrendatários e Parceiros e suas Aspirações quanto ao Cultivo de uma Área Maior, Vale do Ribeira, 1973.

\begin{tabular}{|c|c|c|c|}
\hline \multirow{2}{*}{ Aspiraçöes } & \multicolumn{3}{|c|}{ CATEGORIAS DE TRABALHADORES } \\
\hline & $\begin{array}{l}\text { proprietä- } \\
\text { rios } \\
\qquad \%\end{array}$ & $\begin{array}{c}\text { arrenda- } \\
\text { tärios } \\
\quad \%\end{array}$ & $\begin{array}{c}\text { parceiros } \\
\%\end{array}$ \\
\hline $\begin{array}{l}\text { pretendem cultivar } \\
\text { uma área maior }\end{array}$ & 67,8 & 87,4 & 44,4 \\
\hline $\begin{array}{l}\text { não pretende culti } \\
\text { var uma área maior }\end{array}$ & 32,2 & 12,6 & 55,6 \\
\hline \multirow{2}{*}{ TOTAL } & 100,0 & 100,0 & 100,0 \\
\hline & (59) & (32) & $(18)$ \\
\hline
\end{tabular}

dos de introduzirem melhoramentos nas propriedades que tomam em parceria. Esses melhoramentos têm levado muitos proprietá rios a aumentarem suas quotas sobre as colheitas, aumentando assim as despesas dos parceiros e reduzindo ainda mais suas rendas já bastante limitadas. Assim, isto representa como que uma punição dos parceiros pelos trabalhos de melhoramen to que realizaram, e em parte explica porque muitos não procuram evoluir em suas ocupações, permanecendo nas situaçōes dificeis em que geralmente se encontram. 
TABELA 18. Frequência e Percentagem dos Agricultores, segundo as Categorias de Trabalhadores Agrícolas e sua procura de Trabalho Adicional, Vale do Ribeira, 1973.

\begin{tabular}{|c|c|c|c|c|}
\hline \multirow[t]{2}{*}{$\begin{array}{l}\text { categorias de tra- } \\
\text { balhadores }\end{array}$} & \multicolumn{2}{|c|}{$\begin{array}{l}\text { procuram trabalho } \\
\text { adicional }\end{array}$} & \multicolumn{2}{|c|}{$\begin{array}{l}\text { não procuram traba } \\
\text { lho adicional }\end{array}$} \\
\hline & $n$ & $\%$ & $\mathrm{n}$ & $\%$ \\
\hline proprietärio & 10 & 16,9 & 49 & 83,1 \\
\hline arrendatärio & 3 & 8,9 & 31 & 91,1 \\
\hline parceiros & 3 & 14,3 & 18 & 85,7 \\
\hline assalariados fixos & 7 & 11,4 & 55 & 88,6 \\
\hline assalariados even & & & & \\
\hline tuais & 24 & 47,1 & 27 & 52,9 \\
\hline TOTAL & 47 & 20,7 & 180 & 79,3 \\
\hline
\end{tabular}

A Tabela 18 mostra a distribuiçāo dos agricultores segundo as categorias de trabalhadores agrícolas e sua procura de trabalho adicional. Através dela verificamos que, $79,3 \%$ dos agricultores não procuram desenvolver outro trabalho ao lado de suas ocupações principais e a maioria dos que procuram, isto é, $51,1 \%$ são assalariados eventuais. 
Quase a metade desses assalariados $(47,1 \%)$ buscam trabalhos adicionais, enquanto que apenas $8,9 \%$ dos arrendatärios e $11,4 \%$ dos assalariados fixos buscam esses trabalhos. Portanto, a maioria dos agricultores estudados não pretende ter mais de uma ocupação e, de fato, apenas $37,1 \%$ deles exerce efetivamente outra ocupação ao lado de suas ocupações principais .

Segundo RAMSOY (1966), a mobilidade social das pessoas, na zona urbana, depende mais das oportunidades que - ambiente lhes oferece do que de suas próprias capacidades psíquicas ou intelectuais. Na zona rural, entretanto, os fatores psicolögicos parecem influir mais que os ambientais, uma vez que alí as oportunidades de mobilidade tendem a ser as mesmas para muitas pessoas e parecem ser poucas as que aproveitam. A percepção das chances de mobilidade ou de sucesso difere entre as pessoas e por isto diferem também seus esforços nesse sentido. E assim que os fatores psicolögicos influenciam a mobilidade e influenciam ainda mais se as pessoas vêem suas ocupações como um meio de obterem mais poder, mais prestígio, ou sucesso. Na zona rural, entretanto, são poucas as pessoas que vêem suas ocupaçōes assim. Entre os agricultores de baixa renda aqui estudados, por exemplo, as ocupaçōes geralmente são vistas apenas como um meio de sobre vivência. Esta é uma das razōes pelas quais geralmente eles não procuram ocupações melhores que as suas, ou nelas não 
procuram evoluir.. De fato, segundo RAMSOY, na sociedade de subsistência, onde se procura apenas garantir o alimento, ge ralmente a iniciativa para subir socialmente não é incentiva da e isto faz com que também não seja incentivada a iniciat va para subir ocupacionalmente.

Na zona rural, na ëpoca das safras, as oportunidades de trabalho tendem a aumentar em todas as categorias de trabalhadores, pois, aumenta a demanda da mão-de-obra que, inclusive pode se tornar escassa. No período das entre-safras, entretanto, essa demanda cai e, então, muitas pessoas ficam desempregadas e outras assumem ocupaçōes adicionais pa ra compensar a redução que tiveram em suas rendas. Nessas épocas observa-se que a região estudada tende a favorecer as oportunidades de emprego fora da agricultura, principalmente devido à sua localização relativamente pröxima aos grandes centros como São Paulo e Santos. Por essa razão, segundo PATRICK (1975b), na época das safras jä chega a haver certa carência de mão-de-obra na região. Assim, vemos que é mais na ëpoca das entre-safras que os agricultores aumentam suas chances de mobilidade, uma vez que é este o período em que eles mais se esforçam para conseguirem trabalho ou ocupaçöes adicionais, seja no setor agrícola ou mesmo fora dele.

Por trabalho ou ocupação adicional entendemos, aqui, todo trabalho ou ocupação efetivamente exercida pelos agricultores fora de sua principal unidade de produção. Este 
trabalho influencia grandemente a mobilidade dos agricultores e, por essa razão, organizaçōes os dados tambëm como mostra a Tabela 19.

TABELA 19. Distribuição Percentual dos Agricultores, segundo as Categorias de Trabalhadores Agrícolas, relativas aos seus Trabalhos Principais e Adicionais, Vale do Ribeira, 1973.

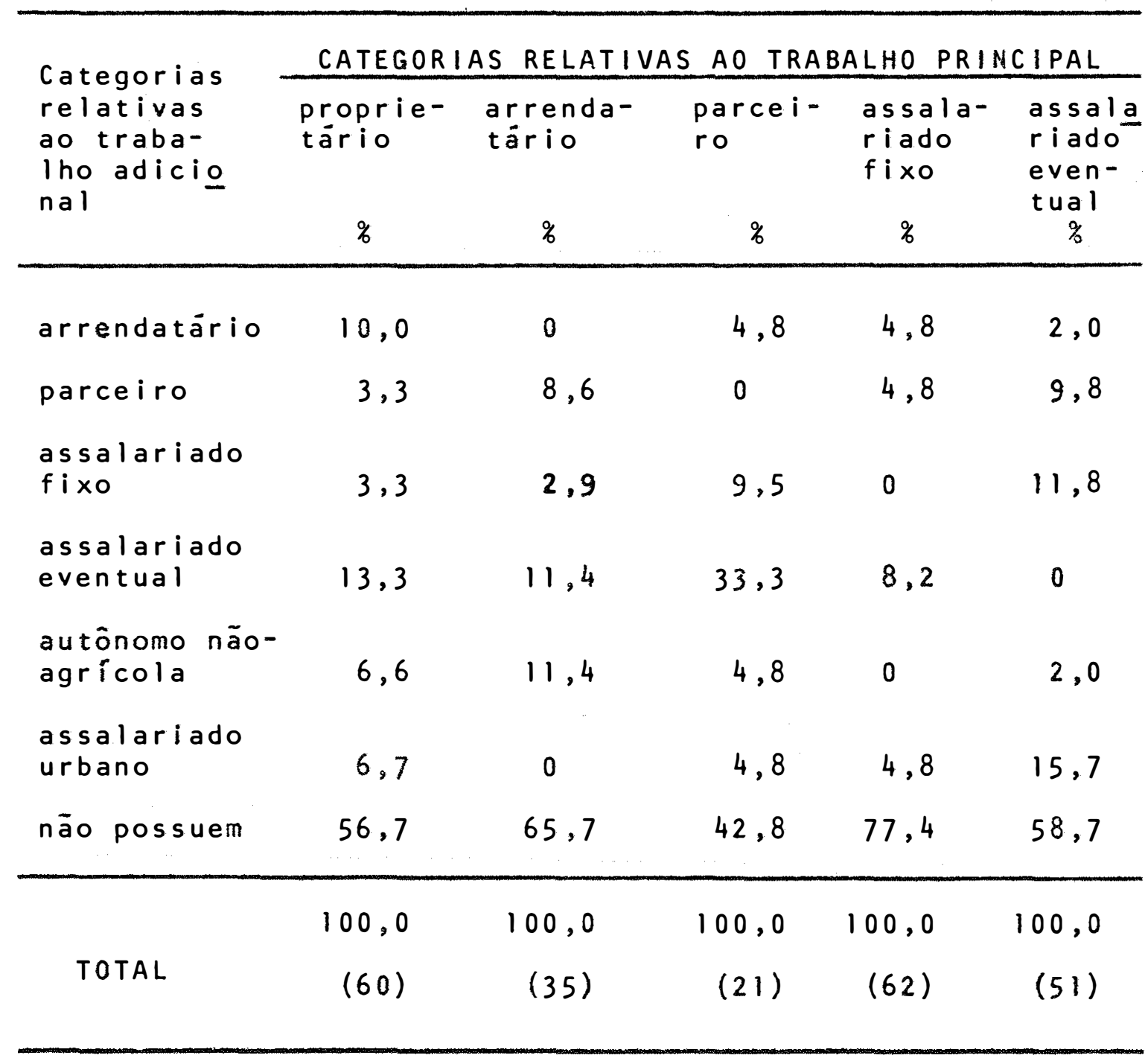


A Tabela 19 expõe a distribuição dos agriculte res estudados, segundo as categorias de trabalhadores relat vas aos seus trabalhos principais e adicionais. Cerca de $37,1 \%$ dos agricultores entrevistados possuem trabalhos adicionais e, como mostra esta tabela, mais frequentemente são os parceiros $(57,2 \%)$ e os proprietários $(43,3 \%)$ que possuem esses trabalhos. Segundo esses dados, mais frequentemente também, os agricultores entrevistados tendem a ser assalaria dos eventuais em seus trabalhos adicionais. Segundo PATRICK (1975b:20), na região estudada o trabalho adicional ë uma fonte de renda importante para os parceiros e proprietários, pois chega a representar atē $30,0 \%$ de suas rendas líquidas mensais. Entretanto, esse trabalho sö se torna realmente significativo para os agricultores na época das safras e, mesmo nesse período, não se ampliam muito suas possibilidades de ganho, pois, a demanda da mão-de-obra oscila e ë bastante limitada na região.

Segundo WILENSKY (1966:113), um dos primeiros incentivos que os agricultores recebem para abandonar seu trabalho é quando lhes aparece a oportunidade de serem trabalhadores autônomos. Muitos agricultores hoje em dia desejam não ter patrōes, embora as oportunidades, nesse sentido, jă tenham diminuido bastante para a maioria deles. Na popula ção estudada, o fato do agricultor não ter patrão implica num alto grau de prestígio e por isso muitos procuram ser a $\underline{u}$ 
tônomos, mesmo num trabalho adicional. Por exemplo, muitos trabalhadores subordinados alternam seus trabalhos principais com os de tarefeiro na zona rural ou urbana, ou com a realização de pequenos negöcios. E assim que atravēs dos trabalhos adicionais muitos agricultores têm conseguido se transformar, efetivamente, de empregado em trabalhador autô nomo, ou de trabalhador subordinado em profissional independente.

Atualmente as oportunidades de trabalho autôno mo tendem a diminuir, na agricultura, devido ao desenvolvimen to da burocratização. Ho setor agrícola, a burocratização das atividades tem aumentado com o desenvolvimento das técni cas e do modo de produção e se traduz, por exemplo, no número cada vez maior de trabalhadores rurais que estão se trans formando em operärios agrícolas. Na região estudada observase que o aumento na burocratização do trabalho tende a diminuir as chances de mobilidade dos agricultores, principalmente porque dificulta sua transformação em trabalhadores au tônomos e passa a exigir deles mais escolaridade para sua evolução nas ocupações. E assim que, na região estudada, mui tos agricultores não mais têm podido realizar seus negöcios independentes e muitos não mais têm conseguido mudar dos trabalhos manuais ou braçais para os não-manuais. Segundo SMELSER e LIPSET (1966), entretanto, a burocratização do tra balho pode também facilitar a mobilidade dos trabalhadores, 
na medida em que estrutura as ocupações em carreiras e organiza a passagem entre as categorias ocupacionais ou entre as categorias dos trabalhadores. Obviamente, porém, essa passagem só é facilitada se os trabalhadores têm os recursos exigidos pela burocracia nesse sentido. Entretanto, como sabemos, geralmente esses recursos não têm estado ao alcance dos agricultores e, por essa razão, o aumento na burocratização do trabalho mais tem dificultado do que facilitado sua mobilidade.

Como temos observado, o Vale do Ribeira representa uma das regiões agrícolas mais pobres do Estado de São Paulo e nessa região nos propusemos estudar apenas os agricultores de baixa renda. Consequentemente no presente trabaTho é bastante significativa a analise dos agricultores que estão imobilizados no fundo da estrutura ocupacional, ou seja, na categoria dos assalariados eventuais. Segundo a Tabela 11 , vimos que há um número relativamente grande de agricultores nessa situação, pois, $32,9 \%$ dos filhos dos assalariados eventuais ainda estão imobilizados nessa mesma catego ria de seus pais. Para a maioria desses agricultores, inclusive, esta é a mesma categoria através da qual ingressaram no mercado de trabalho há värios anos. Dada a situação de po breza das famílias desses agricultores, eles integram os grupos dos trabalhadores que estão realmente no fundo da estrutura ocupacional. Muitos deles, às vezes, dificilmente po 
dem ser classificados como trabalhadores regulares, pois estão desempregados a maior parte do tempo ou säo desempregados crónicos. Segundo MATzA $(1966: 314)$, as pessoas que estão no fundo ou abaixo do fundo da estrutura ocupacional integram a categoria dos pobres sem reputação ou dos paupérrimos e, de fato, não pertencem a essa estrutura. o que mais carac teriza esses grupos ë o paperismo em que vivem e este principalmente um produto dos sentimentos de imobilidade e de desterro que experienciam quanto à estrutura ocupacional ou quanto à sua região. Comumente ao pauperismo desses agricultores têm se juntado o vício e a imoralidade que os tornam diferentes dos trabalhadores pobres comuns. Assim, o agricultor paupērrimo é aquele que tem sido classificado como pobre sem reputaçäo; é o indivíduo que, alēm de viver na pobreza, é considerado indolente, inferior e um desclassificado, enfim.

A situação dos agricultores pobres sem reputação tem muito que ver com a dos assalariados eventuais que se imobilizaram no fundo da estrutura ocupacional, uma vez que sua imobilização se deu num nível onde a pobreza transvaria com a imoralidade. De fato, segundo MATZA (1966:336), a categoria dos pobres sem reputação surge, principalmente, quando são fechados os canais de mobilidade para as pessoas sairem de uma região ou de uma categoria pobre. Por isso o paupérrimo geralmente é aquele que se imobilizou numa dessas 
regiões ou categorias. Ele é pobre devido a sua imobilidade na pobreza e é principalmente devido a essa imobilidade que ele se desmoraliza.

Geralmente os agricultores pobres que näo conseguem se manter no campo mudam para as cidades ou para outras regiões. Entretanto, a cada onda dessas emigrações sempre ficam para träs, no campo ou nas regiões pobres, aqueles que não conseguiram nem mesmo emigrar. Alguns desses agricultores se esforçam por manter seus velhos costumes e seus valores tradicionais. Entretanto, geralmente isto apenas tem contribuido para agravar sua situação, levando-os a sérios problemas econômicos e sociais e inclusive à desorganização de suas familias. Ma presente pesquisa pudemos entrevistar alguns desses agricultores tambëm. Eles insistiam em continuar nas fazendas onde sempre moraram, embora atualmente se que xem contra os "bandos de gente nova" que, à cada safra vêm morar em suas vizinhanças e com os quais eles têm que trabalhar mesmo contra suas vontades. Para esses antigos moradores, as novas pessoas que temporariamente têm ido morar nas fazendas são "gente estranha", gente que não têm os seus cos tumes, as suas tradições e, por isso, eles não confiam nelas. Segundo os antigos moradores, os agricultores recém-che gados têm levado para a vida nas colónias os costumes dos lugares de onde vieram e isto tem contribuido para enfraque cer suas tradições ou seus costumes locais. Em geral os re- 
cém-chegados logo no início mostram otimismo quanto ao seu futuro no novo lugar. Entretanto, também eles acabam aderindo às atitudes conformistas dos antigos moradores, na medida em que suas misérias e privaçōes vão se tornando comuns. Isto acontece principalmente quando os membros mais jo vens das famílias recém-chegadas emigram para as cidades ou para outras regiōes, deixando os mais velhos para träs. Entre as antigas famílias muitos jovens também abandonam o cam po para viver nas cidades, porēm muitos deles tambēm aderem ao modo de pensar dos mais velhos, insistindo em continuar morando nas fazendas e se imobilizando em suas categorias de trabalhadores. E desta maneira que os dramas do pauperismo no campo vão envolvendo esses agricultores e vão se agravando principalmente para aqueles que fracassaram na mobilidade e se imobilizaram numa região pobre, numa categoria do fundo ou abaixo do fundo da estrutura ocupacional. 
V. CONCLUSOES

Na presente pesquisa analisamos a mobilidade social dos agricultores de baixa renda do Vale do Ribeira, no Estado de Sāo Paulo, atravēs de uma hierarquia composta pelas seguintes categorias, segundo sua ordem decrescente de prestígio: 1) proprietärios, 2) arrendatärios, 3) parceiros, 4) assalariados fixos e 5) assalariados eventuais. Verificamos que, nas categorias mais prestigiadas, a receita mensal das familias tende a ser maior e vice-versa. Entretanto, $75,8 \%$ das familias dos assalariados fixos, por exemplo, tinham uma receita mensal maior que a da maioria das familias dos parceiros e arrendatärios. Conclui-se portanto que, muitas dessas familias de agricultores podem descer na hierarquia de prestigio, ainda que haja um aumento em suas recei- 
tas mensais.

os estudos sobre a mobilidade social têm demonstrado que, de um modo geral os filhos permanecem nas mes mas categorias sócio-económicas de seus pais. Na presente pesquisa, inicialmente foi isto tambēm o que verificamos, considerando apenas tres amplas categorias de agricultores, ou sejam: 1) a dos proprietários, 2) a dos arrendatärios e parceiros e 3) a dos assalariados fixos e eventuais. 0 respectivo $x^{2}$ demonstrou que, num nivel de significância de 0,05, hả associação entre a classificação dos agricultores e de seus pais nessas categorias: a maioria dos agricultores estão nas mesmas categorias de seus pais e, de um modo geral todos eles sāo filhos de agricultores. Isto slgnifica que, há uma herança ocupacional deixada por esses agriculto res aos seus filhos eque, hä certa imobilidade na estrutura ocupacional estudada. Entretanto a associação encontrada relativamente fraca, pois, seu coeficiente de contingência foi apenas 0,241 quando poderia ser até 0,816 . Além disso as tres categorias consideradas são excessivamente amplas e, assim, podem estar escondendo a mobilidade que dentro delas ocorre. Passamos entāo a considerar as cinco categorias que inicialmente foram definidas, e, verificamos que näo mais havia associação entre a classificação dos agricultores e de seus pais em relação a elas, naquele mesmo nível de significância: apenas $32,0 \%$ dos agricultores permaneceram na 
mesma categoria de seus pais, 19,1\% mudaram para categorias superiores e $48,9 \%$ desceram para categorias inferiores. Isto demonstra que houve significativa mobilidade na população es tudada e que quase a metade dos agricultores está insatisfei ta com a estrutura ocupacional da regiāo devido à sua mobilidade descendente.

As categorias de agricultores que demonstraram maior força na determinação das categorias dos filhos foram as dos proprietários e arrendatärios. Mesmo assim,apenas 1,7 de cada 5 filhos dos proprietärios e apenas 2,1 de cada 5 filhos dos arrendatários continuaram na mesma categoria de seus pais. Logo, mesmo nas categorias do topo da estrutura ocupacional é grande a mobilidade e, como vimos, geralmente ela ocorre em direçāo ao fundo dessa estrutura. No sentido inverso, vimos que $25,7 \%$ dos filhos dos assalariados fixos e $24,0 \%$ dos filhos dos assalariados eventuais ternaram-se proprietários. Entretanto, essa mobilidade do fundo para o topo da estrutura ocupacional foi a mais rara. Assim, como noutros estudos tambèm aqui verificamos que, a tendência em permanecer nas categorias dos pais foi bem menor no fundo do que no topo da estrutura ocupacional.

os custos da mobilidade tendem a ser mais elevados quando ela $\vec{e}$ descontinua. Os casos mais extremos dessa mobilidade, na população estudada, referem-se às mudanças da categoria dos proprietärios para a dos assalariados even- 
tuais. Cerca de $17,0 \%$ dos filhos dos proprietários realizaram essa mobilidade. A mobilidade parcialmente bloqueada tam bém resulta em muita frustração para os trabalhadores. Na população estudada, por exemplo, $24,0 \%$ dos que iniciaram suas carreiras como filhos de assalariados eventuais conseguiram tornar-se apenas assalariados fixos e $20,0 \%$ subiram apenas até as categorias dos parceiros e arrendatários. Para esses então, as aspiraçōes de alcançar as categorias mais elevadas continuam insatisfeitas devido a sua mobilidade par cialmente bloqueada. Como a população estudada se constitui num grupo de baixa renda, nela são poucos os canais de mobilidade. Por isso, frequentemente seus agricultores também têm desenvolvido a mobilidade não institucionalizada. Isto geralmente os tem levado aos empregos instáveis e às emigraçōes, introduzindo muita desorganização na estrutura ocupacional. Nesse sentido vimos, por exemplo, que $22,3 \%$ dos agri cultores são assalariados eventuais, $68,0 \%$ são möveis na estrutura ocupacional e $37,1 \%$ exercem efetivamente outras ocupações ao lado de suas ocupações principais. Sem dúvida isto contribui para aumentar a mobilidade não institucionaliza da na população e como nela também são frequentes a mobilida de descontinua e a parcialmente bloqueada, concluimos que hä muita tensão, ressentimentos e frustraçöes em sua estrutura ocupacional.

A adoção da tecnologia moderna na agricultura 
.111.

e as aplicaçōes do Estatuto da Terra e Estatuto do Trabalhador Rural têm introduzido muitas mudanças na estrutura ocupacional da populaçāo estudada. A mobilidade dos seus agricultores tem sido um dos meios deles se adaptarem a essas mü danças. Assim, vimos que em todas as categorias de trabalhadores,excetri na dos proprietärios, foi sempre maior o nüme ro de agricultores oriundos de outras categorias. 0 volume da categoria dos proprietärios foi reduzido de $56,5 \%$ para $28,3 \%$, e os das demais aumentaram bastante, na estrutura ocu pacional relativa aos agricultores, em comparação com os das categorias da estrutura relativa a seus pais. Portanto, as categorias estudadas têm contribuido mais para a mudança do que para a estabilidade da estrutura ocupacional e essa mudança $\bar{e}$ mais no sentido de reduzir os volume das categorias do topo, aumentando os das categorias do fundo dessa estrutú ra. Em consequência essa mobilidade tem levado ao enfraquecimento das tradiçōes nas categorias dos trabalhadores e tem modificado a estrutura ocupacional da populaçāo principalmente no sentido da proletarizaçāo dos agricultores.

As pessoas sentem-se mais estimuladas à mobili dade quando vêem suas ocupaçöes como um meio de obterem sucesso. Entretanto, entre os agricultores de baixa renda dif cilmente isto ocorre pois, para eles geralmente as ocupaçöes representam apenas um meio de sobrevivência e isto não os es timula a evoluir ocupacionalmente. Assim, $32,0 \%$ dos agricuI 
.112

tores estudados estäo imobilizados no fundo da estrutura ocu pacional, isto é, na categoria dos assalariados eventuais e sua situação de pobreza os tem transformado em paupērrimos, ou seja, em pobres sem reputação. O pauperismo desses agricultores tem muito que ver com sua imobilidade pois, é consequência de se terem fechado para eles os canais da mobilidade que os levaria para fora de uma categoria pobre. São esses agricultores principalmente que vivem os dramas da pobre za, da desmoralizaçāo e desorganização da famillia, muito comuns entre os que fracassaram na mobilidade e se imobilizaram no fundo da estrutura ocupacional. 
.113

\section{BIBLIOGRAFIA}

BRASIL. Fundaçāo Getülio Vargas, 1956. Conjuntura Econômica. $n$ : $12: 71-77$.

BRASIL. Fundação Instituto Brasileiro de Geografia e Estatís tica, 1970. Divisão do Brasil em Micro-regiões Homogêneas, 1968. Rio de Janeiro.

BRASIL. Fundação Instituto Brasileiro de Geografia e Estatís tica, 1970. VIII Recenseamento Geral - Cens. Demogräfico de São Paulo. Vol. 1, tomo XVIII, 3a. parte.

BROOM, L, e P. SELZNICK, 1963. Sociology. New York, Harper \& Row Publishers Incorporated. 746 p., 3a. edição.

BROOA, L. e P. SELZNICK, 1968. Sociology. Hew York, Harper \& Row Publishers Incorporated. 562 p., 4a. edição. 
.114.

CROCKETT. JR., H.J.; 1966. Psychological Origins of Mobility. In: SMELSER, H.J. e S.M. LIPSET, Coord. Social Structure and Mobility in Economic Development. Chicago, Aldine Publishing Company, p. 280-308.

DUNCAN, 0.D., 1966. Methodological Issues in the Analysis of Social Mobility. In: SMELSER, H.J. e S.M.LIPSET, Coord. Social Structure and Mobility in Economic Development. Chicago, Aldine Publishing Company, p. 51-96.

EE.UU. Comitè Interamericano de Desenvolvimento Agrícola, 1966. Posse e uso da Terra e Desenvolvimento Sócia-Economico do Setor Agrícola - Brasil. Washington D.C.

ETTORI, 0.J.T., 1961. Mão-de-Obra na Agricultura de São Pau10. Agricultura em São Paulo. n? 12:13-39.

FOLKMAN, H.S. E J.D. COUHIG, 1963. Intergenerational Occupational Mobility in a Rural Area. Rural Sociology. Vol.28: 405-407.

GALESKI, B., 1972. Basic Concepts in Rural Sociology. Manches ter, Hanchester University Press, $382 \mathrm{p}$.

GERMANI, G., 1966. Social and Political Consequences of Mobility. In: SMELSER, N.J. e S.M.LIPSET, Coord. Social Structure and Mobility in Economic Development. Chicago, Aldine Publishing Company, p. 364-394.

HALLER, A.0., D.B.HOLSINGER e H.V.SARAIVA, 1972. Variations in Occupational Prestige Hierarchies:Brazilian Data American Journal of Sociology. Vol. 77:941-956. 
HILL, G.H. e H.T.CHRISTENSEN, 1942. Some Cultural Factors Related to occupactional Mobility Among Wisconsis Farmers. Rural Sociologgy. Vol. 7:193-200.

MOSELITZ, B.F., 1966. Interaction Between Industrial and PreIndustrial Stratification Systems. In: SMELSER, N.J. e S. M. LIPSET, Coord. Social Structure and Mobility in Economic Development. Chicago, Aldine Publishing Company, p. $177-192$.

HUTCHINSON, B., Coord., 1960. Mobilidade e Trabalho. Rio de Janeiro, D.F., Centro Brasileiro de Pesquisas Educacionais. $451 \mathrm{p}$.

KAUFMAN, H.F., O.D. DUNCAN, H. GROSS e W.H. SEWELL, 1953. Problems of Theory and Method in the Study of Social Stratification in Rural Society. Rural Sociologgy. Vol.18: $12-24$.

LIPSET, S.M., 1955. Social Mobility and Urbanization . Rural Sociology. Vol. 20:220-228.

MARSHALL, A., 1963. Principios de Economia. Madrid, Aguilar, S.A. de Ediciones. 733 p.

MATZA, D., 1966. The Disreputable Poor. In:SMELSER, N.J. e S.H. LIPSET. Coord. Social Structure and Mobility in Economic Development. Chicago, Aldine Publishing Company, p. $310-339$.

MOLINA FILHO, J., 1977. Unidades de Produção Agrícola no Bra sil. O Solo. Piracicaba, 1:7-14. 
MOORE, W.E., 1966. Changes in Occupational Structures. In: SMELSER, N.J. e S.M. LIPSET, Coord. Social Structure and Mobility in Economic Development. Chicago, Aldine Publishing Company, p. 194-212.

PAStORE, J., 1974. O Processo de Decisão sob condiçōes de $\underline{I n}$ certeza e Risco:- Caso da Agricultura de Subsistência no Brasil. São Paulo, Instituto de Pesquisas Econōmicas-USP. $25 \mathrm{p}$.

PATRICK, G.F., 1975. Grupos de Pobreza na Agricultura Brasileira. São Paulo, Instituto de Pesquisas Econōmicas USP. 43 p.

PATRICK, G.F., 1975. Pobreza Rural no Brasil:Determinantes $e$ Alternativas. São Paulo, Instituto de Pesquisas Econōmicas-USP. $36 \mathrm{p}$.

PEREZ, L.H., 1975. Caracterizaçāo de Areas Agrícolas Brasileiras Segundo suas Formas de Produçāo. Piracicaba,ESALQ/ USP, $184 \mathrm{p}$. (tese de Mestrado).

PIHLBLAd, C.T. e C.L. GREgORY, 1957. Occupational Mobility in Small Communities in Missoury. Rural Sociology. Vol. $22: 40-49$.

QUEIROZ, M.1.P. de, 1965. Les Classes Sociales dans le Brêsil Actuel. Cahiers Internationaux de Sociologie. Vol. $39: 15-26$.

RAMSOY, N.R., 1966. Changes in Rates and Forms of Mobility. In: SMELSER,N.J. e S.M. LIPSET, Coord. Social Structure and Mobility in Economic Development. Chicago, Aldine Publishing Company, p.213-234. 
SELIGMAN, L.G., 1966. Political Mobility and Development. In: SMELSER, N.J. e S.M.LIPSET, Coord. Social Structure and Mobility in Economic Development. Chicago, Aldine Publishing Company, p. 340-363.

SIMATO, A. e F. GOLDMAN, 1958. Itanhaém-Estudo sobre o Desenvolvimento Econômico e Social de uma Comunidade Litonânea. Säo fauto, Eaculdade de Filosofia, Cièncias e Letras-USf. 109 p.

SJOBERG, G., 1966. Rural-Urban Balance and Models of Economic Development. In:SMELSER, N.J. e S.M. LIPSET, Coord. Social Structure and Mobility in Economic Development. Chicago, Aldine Publishing Company, p. 235261 .

SMELSER, M.J. e S.M. LIPSET, 1966. Social Structure,Mobility and Development. In:SMELSER, N.J. e S.M.LIPSET, Coord. Social Structure and Mobility in Economic Development.Chi cago, Aldine Publishing Company, p. $1-49$.

SMITH, M.G., 1966. Pre-Industrial Stratification Systems. In:SMELSER, N.J. e S.M.LIPSET, Coord. Social Structure and Mobility in Economic Development. Chicago, Aldine Publishing Company, p. 141-175.

WILENSKY, H.L., 1966. Measures and Effects of Mobility. In: SMELSER, N.J. e S.M. LIPSET, Coord. Social Structure and Mobility in Economic Development. Chicago,Aldine Publishing Company, p. 98-133. 
$\stackrel{A}{=}=\underline{P}=\underline{\underline{E}}=\underline{\underline{N}}=\underline{\underline{D}}=\underline{\underline{1}}=\underline{\underline{C}}=\underline{\underline{\underline{C}}}$ 
APENDICE 1. Rabilidade dos Agricultores Filhos dos Proprietários.

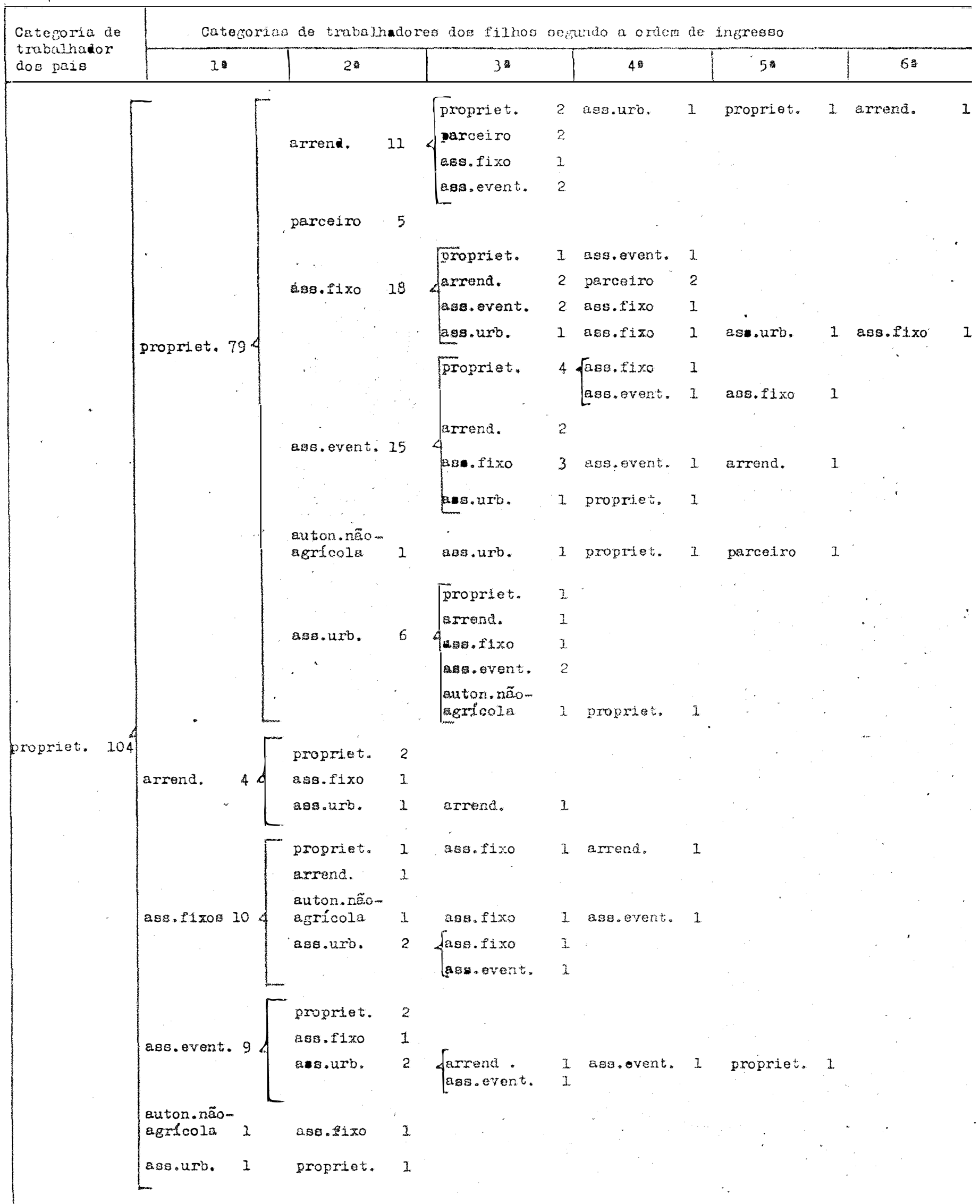

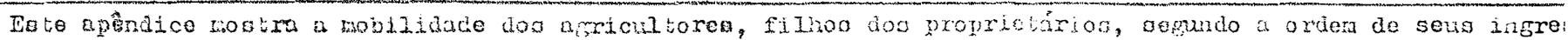

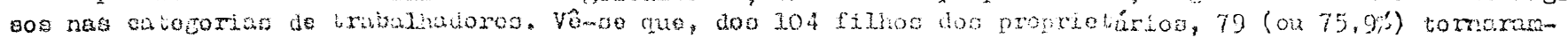

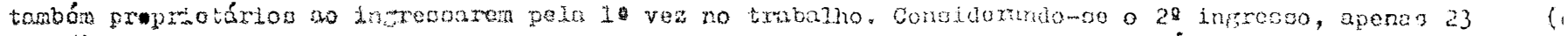

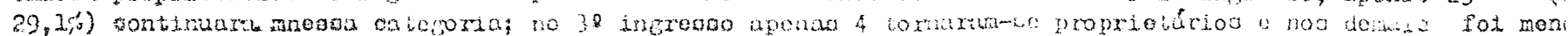

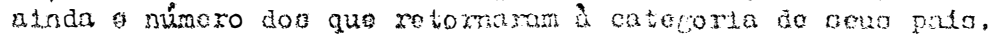




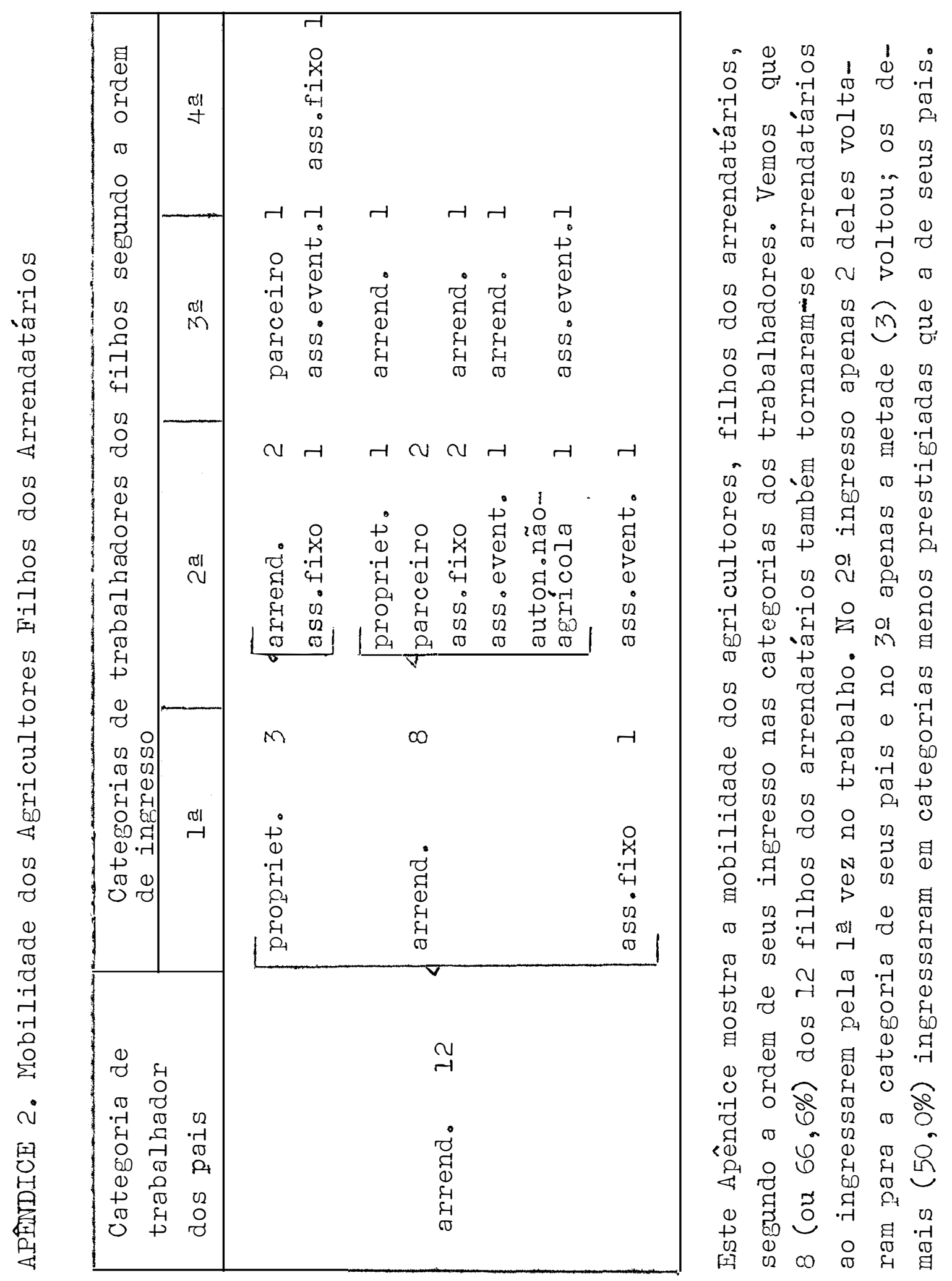


APEDICE 3. Nobilidade dos Africultores Filhos dos Assalariados Fixos

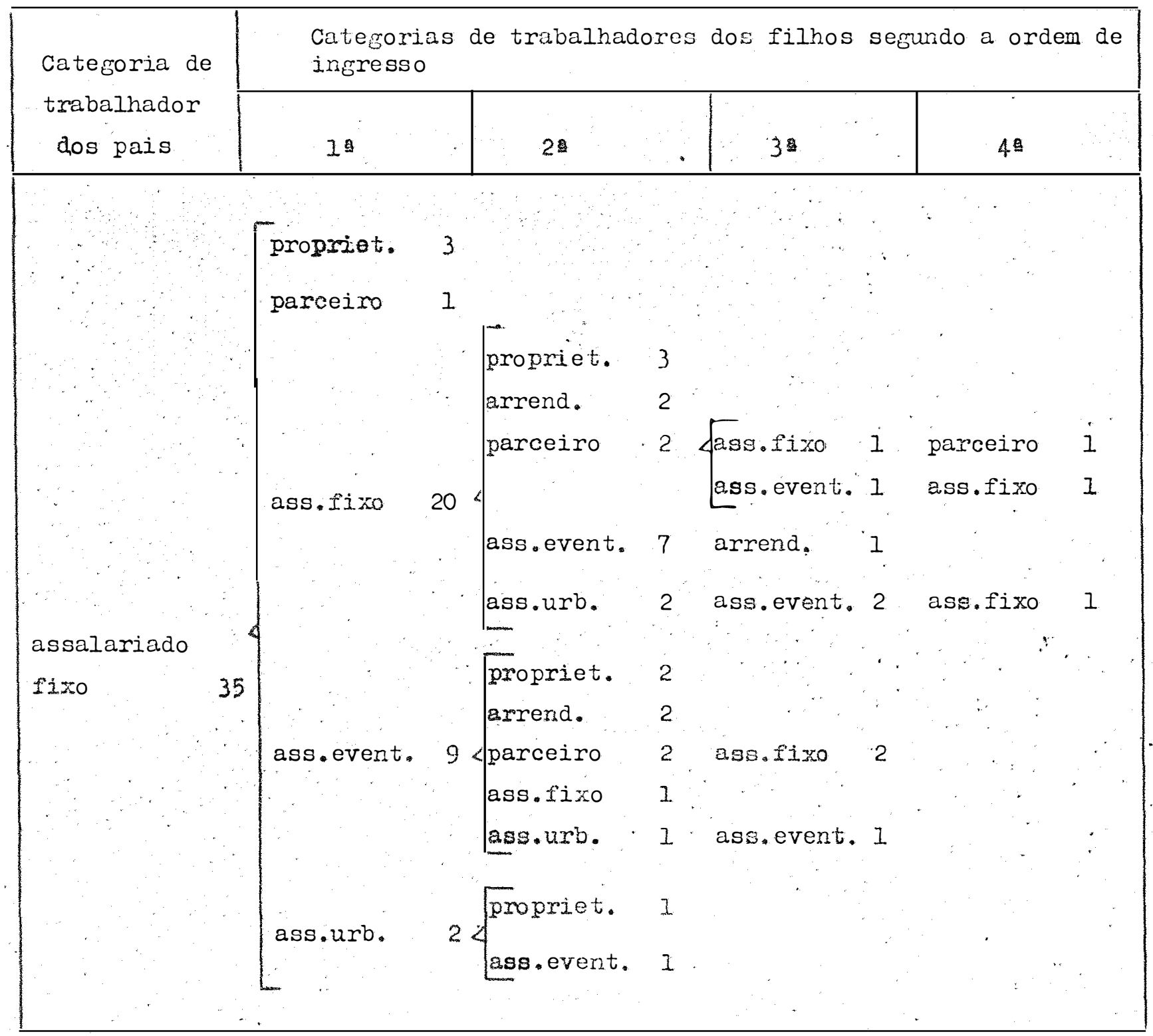

Este apêndice mostra a mobilidade dos aqricultores, filhos dos assalariados fi. zos, segundo a ordem de seus ingressos nas categorias de trabalhadores. Observe se que 57,1\% (ou 20) desses agricultores tomaran-se tarbém assalariados fixos ao ingressarem pela 1 . vez no traballio. Quanto às mudanças posteriores, vemos que apenas 5 retomaram aे categoria de seus pais, enquanto que a maioria dos restantes tomaram-se apenas assalariados eventuais. 


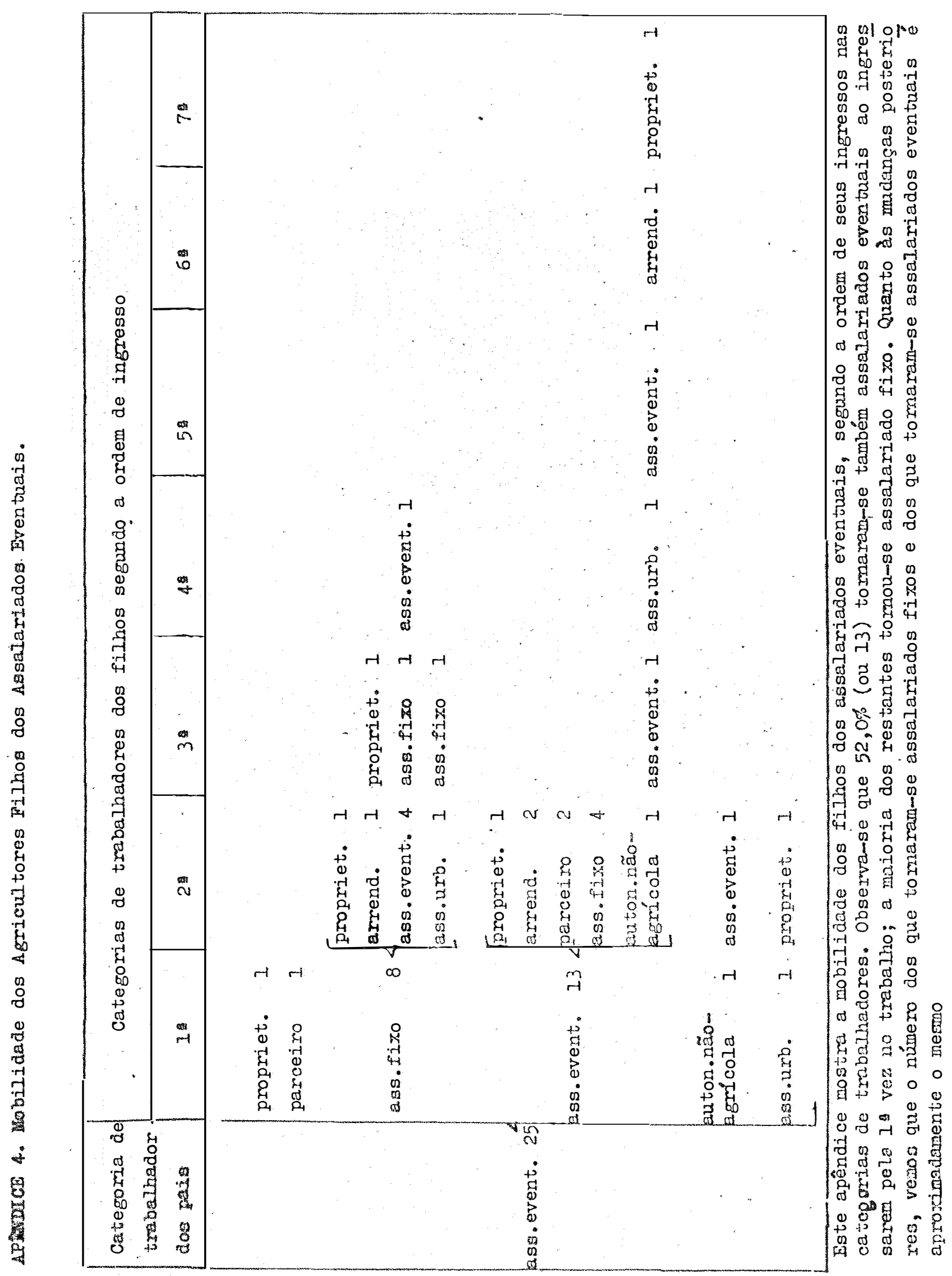




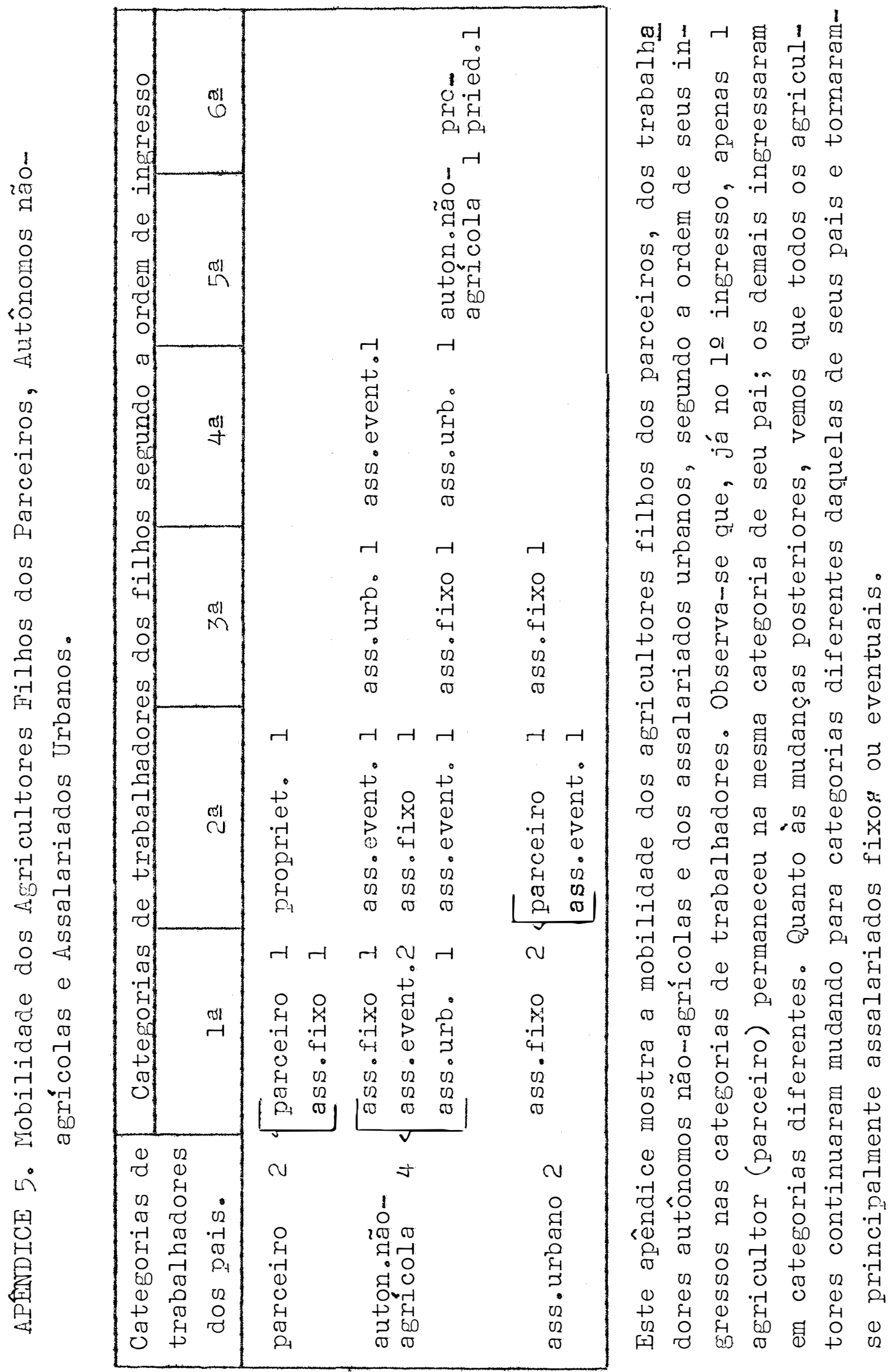


APENDICE 6. TABELA 20. Distribuição do Total dos Imóveis Rurais do Vale do Ribeira, em 1972.

\begin{tabular}{|c|c|c|c|c|}
\hline \multirow{2}{*}{\multicolumn{2}{|c|}{ ärea total (ha) }} & \multirow{2}{*}{$\frac{\text { nümero }}{\text { total }}$} & \multirow{2}{*}{$\frac{\mathrm{de}}{\mathrm{com}}$} & \multirow{2}{*}{$\frac{\text { imöveis }}{\text { ärea explorad }}$} \\
\hline & & & & \\
\hline 0,5 & -1 & 58 & & 35 \\
\hline$i$ & -2 & 103 & & 74 \\
\hline 2 & -5 & 502 & & 361 \\
\hline 5 & -10 & 615 & & 471 \\
\hline 10 & -25 & 2.314 & & 1.702 \\
\hline 25 & -50 & 1.701 & & 1.276 \\
\hline 50 & -100 & 1.089 & & 816 \\
\hline 100 & -200 & 615 & & 438 \\
\hline 200 & -500 & 438 & & 276 \\
\hline 500 & -1000 & 145 & & 93 \\
\hline 1000 & -2000 & 83 & & 51 \\
\hline 2000 & -5000 & 54 & & 36 \\
\hline 5000 & -10000 & 6 & & 3 \\
\hline 10000 & -20000 & 5 & & 1 \\
\hline 20000 & e mais & 1 & & - \\
\hline TOTAL & & 7.729 & & 5.633 \\
\hline
\end{tabular}

FONTE: L.H.PEREZ (1975:166 
APENDICE 7. TABela 21. Distribuição da Ocupação Humana dos Imóveis Rurais do Vale do Ribeira, em 1972.

\begin{tabular}{|c|c|c|c|c|c|}
\hline \multicolumn{2}{|c|}{ (ha) } & $\begin{array}{l}\text { residentes } \\
\text { por imóvel }\end{array}$ & $\begin{array}{l}\% \text { de mora } \\
\text { dias deso } \\
\text { cupadas }\end{array}$ & $\begin{array}{l}\% \text { de fami } \\
\text { lias en- } \\
\text { treos re } \\
\text { sidentes }\end{array}$ & $\begin{array}{l}\text { familias } \\
\text { por imó- } \\
\text { vel }\end{array}$ \\
\hline 0,5 & -1 & 5,3 & 2,5 & 36,4 & 1,2 \\
\hline 1 & -2 & 4,3 & 24,7 & 51,4 & 0,9 \\
\hline 2 & -5 & 4,1 & 13,4 & 51,8 & 0,8 \\
\hline 5 & -10 & 4,7 & 20,3 & 49,6 & 0,9 \\
\hline 10 & -25 & 5,4 & 21,8 & 42,5 & 1,0 \\
\hline 25 & -50 & 6,7 & 24.9 & 31,0 & 1,4 \\
\hline 50 & -100 & 8,4 & 25.0 & 22,5 & 1,8 \\
\hline 100 & -200 & 10,7 & 30,2 & 19,3 & 2,2 \\
\hline 200 & -500 & 12,7 & 24,1 & 10,0 & 2,9 \\
\hline 500 & -1000 & 19,4 & 24,6 & 7,4 & 4,5 \\
\hline 1000 & -2000 & 20,3 & 21,3 & 6,6 & 5,2 \\
\hline 2000 & -5000 & 37,9 & 19,8 & 0,1 & 9,7 \\
\hline 5000 & -10000 & 70,0 & 23,7 & 0,0 & 15,0 \\
\hline 10000 & -20000 & 0,0 & 100,0 & 0,0 & 0,0 \\
\hline TOTA & & 7,3 & 23,9 & 28,1 & 1,5 \\
\hline
\end{tabular}

FONTE: L.H.PEREZ (1975:181) 
APEHDICE 8. TABELA 22. Distribuição da Mão-de-obra Agrícola, segundo a Area dos Imōveis Rurais, no Vale do Ribeira, em 1972 .

\begin{tabular}{|c|c|c|c|c|c|}
\hline \multirow[b]{2}{*}{$\begin{array}{l}\text { ärea } \\
\text { lha }\end{array}$} & \multirow[b]{2}{*}{$\begin{array}{l}\text { total } \\
\text { ) }\end{array}$} & $\% \mathrm{de}$ & mão-de-obra & \multicolumn{2}{|l|}{ tota 1} \\
\hline & & $\begin{array}{l}\text { assalaria } \\
\text { do perma- } \\
\text { nente }\end{array}$ & $\begin{array}{l}\text { assalaria- } \\
\text { do tempo- } \\
\text { rärio }\end{array}$ & $\begin{array}{l}\text { mão-de- } \\
\text { obra fami } \\
\text { lial }\end{array}$ & $\begin{array}{l}\text { parceiros } \\
\text { e arrenda } \\
\text { tários }\end{array}$ \\
\hline 0,5 & -1 & 4,1 & 41,7 & 54,2 & 0,0 \\
\hline$i$ & -2 & 4,0 & 24,0 & 72,0 & 0,0 \\
\hline 2 & -5 & 4,9 & 31,4 & 61,4 & 2,3 \\
\hline 5 & -10 & 7,4 & 30,3 & 61,0 & 1,3 \\
\hline 10 & -25 & 10,0 & 41,2 & 46,8 & 2,0 \\
\hline 25 & -50 & 18,7 & 44,8 & 34,4 & 2,1 \\
\hline 50 & -100 & 18,7 & 42,0 & 26,2 & 3,1 \\
\hline 100 & -200 & 26,7 & 42,2 & 26,6 & 4,5 \\
\hline 200 & -500 & 27,2 & 56,9 & 12,9 & 3,0 \\
\hline 500 & -1000 & 27,5 & 60,5 & 7,4 & 4,6 \\
\hline 1000 & -2000 & 40,7 & 50,6 & 4,2 & 4,5 \\
\hline 2000 & -5000 & 45,6 & 53,8 & 0,5 & 0,1 \\
\hline 5000 & -10000 & 28,6 & 0,0 & 71,4 & 0,0 \\
\hline TOTAL & & 21.8 & 45,1 & 30,4 & 2,7 \\
\hline
\end{tabular}

FOHTE: L.H.PEREZ (1975:180) 
APENDICE 9. TABELA 23. Força de Trabalho na Zona Rural do Es tado de São Paulo, 1955.

\begin{tabular}{lcc} 
Categorias & mil trabalhadores & $\%$ \\
\hline 1 - Colonos & 285 & 20,4 \\
2 - Parceiros & 225 & 16,0 \\
3 - Camaradas por dia & 221 & 15,8 \\
4 - Camaradas por mês & 86 & 6,0 \\
5 - Arrendatärios & 215 & 15,4 \\
6 - Proprietärios & 360 & 26,4 \\
\hline
\end{tabular}

FONTE: O.J.T. ETTORI (1961:14) 